\title{
WestVirginiaUniversity
}

THE RESEARCH REPOSITORY @ WVU

Graduate Theses, Dissertations, and Problem Reports

1999

\section{Acetaminophen stimulates proliferation of breast cancer cells}

\author{
Eugenia Harnagea Theophilus \\ West Virginia University
}

Follow this and additional works at: https://researchrepository.wvu.edu/etd

\section{Recommended Citation}

Theophilus, Eugenia Harnagea, "Acetaminophen stimulates proliferation of breast cancer cells" (1999). Graduate Theses, Dissertations, and Problem Reports. 3170.

https://researchrepository.wvu.edu/etd/3170

This Dissertation is protected by copyright and/or related rights. It has been brought to you by the The Research Repository @ WVU with permission from the rights-holder(s). You are free to use this Dissertation in any way that is permitted by the copyright and related rights legislation that applies to your use. For other uses you must obtain permission from the rights-holder(s) directly, unless additional rights are indicated by a Creative Commons license in the record and/ or on the work itself. This Dissertation has been accepted for inclusion in WVU Graduate Theses, Dissertations, and Problem Reports collection by an authorized administrator of The Research Repository @ WVU.

For more information, please contact researchrepository@mail.wvu.edu. 


\title{
ACETAMINOPHEN STIMULATES \\ PROLIFERATION OF BREAST CANCER CELLS
}

By

Eugenia Harnagea Theophilus

\author{
A DISSERTATION \\ Submitted to \\ The School of Medicine \\ at West Virginia University \\ in partial fulfillment of the requirements \\ for the degree of \\ Doctor of Philosophy \\ in \\ Pharmacology and Toxicology \\ Department of Pharmacology and Toxicology \\ Morgantown, West Virginia \\ 1999
}

Committee Chair:

Michael R. Miller, Ph. D.

Committee Members:

Jeannine Strobl, Ph. D.

Mark Reasor, Ph. D.

Charles Craig, Ph. D.

Vince Castranova, Ph. D.

Key words: acetaminophen, breast cancer cells, proliferation, estradiol, estrogen receptors, metabolism 


\title{
ACETAMINOPHEN STIMULATES PROLIFERATION OF BREAST CANCER CELLS
}

\author{
Eugenia Harnagea Theophilus
}

\begin{abstract}
Acetaminophen is a common analgesic/antipyretic. This research projected investigated the interaction of acetaminophen with breast cancer cells. The first goal was to determine if acetaminophen induces proliferation in cancerous and normal, human breast cells. Pharmacological concentrations of acetaminophen stimulated proliferation $\left({ }^{3} \mathrm{H}\right.$-thymidine incorporation into DNA, \% S phase cells, cell numbers) of estrogen and progesterone receptor positive (ER+/PR+) but not of ER-/PR+ or of ER-/PR- cancer or normal breast cells. The second goal was to determine if estrogen receptors play a role in acetaminophen-induced proliferation of ER+ breast cancer cells. Antiestrogens inhibited acetaminophen-induced proliferation, suggesting that ERs are involved in proliferation. However, acetaminophen did not bind to ERs in ER+ breast cancer cells, indicating that while acetaminophen mimics some of estradiol effects, it does so by a different mechanism. The third goal was to determine if the $p$-phenol moiety in acetaminophen plays a role in the proliferation of ER+ breast cancer cells. The effects of the positional isomers of acetaminophen on proliferation followed the order: $p->m->o-$ acetamidophenol. These findings indicate that the $p$-phenol is important for proliferation of ER+ breast cancer cells. The fourth goal was to determine if metabolism of acetaminophen occurs in breast cancer cells. Microsomes from ER+ breast cancer cells that undergo proliferation in response to acetaminophen did not metabolize acetaminophen to detectable levels except when cells were pretreated with inducers of cytochrome P450. By contrast, ER- breast cancer cells metabolized acetaminophen to detectable levels in both, cells non-induced and induced with cytochrome P450 inducers. The fifth goal was to determine if acetaminophen affects tumor growth in nude mice inoculated with ER+ human breast cancer cells. Acetaminophen $(150 \mathrm{mg} / \mathrm{kg} / \mathrm{day})$, like estradiol, stimulated tumor growth relative to negative controls up to day 36 following inoculation with ER+ cells. However, after day 36, all tumors regressed. Taken together, the data in this project are novel and help to understand the interaction of acetaminophen with breast cancer cells, an area largely understudied.
\end{abstract}




\section{Dedication}

To Paul, who enriches my life 


\section{Acknowledgements}

Special thanks to Dr. Miller whose energy and enthusiasm inspired me and whose great advice I will always remember. Thanks to Dr. Reasor for his incredible care and valuable advice. Thanks to Drs. Strobl, Craig and Castranova for helping me with the committee work. Thanks to Dr. Stamm whose competent input was always appreciated and intellectually stimulating. Thanks to Doina Jickich who advised me to apply for this graduate program. Thanks to my husband for all his help and support. 


\section{TABLE OF CONTENTS}

TITLE PAGE

ABSTRACT

DEDICATION iii

ACKNOWLEDGEMENTS iv

TABLE OF CONTENTS V v

TABLE OF FIGURES viii

CHAPTER I. INTRODUCTION

1. THE NORMAL AND CANCEROUS BREAST 1

1.1 General Aspects Related to the Normal and Cancerous Breast 1

1.2 Estrogen and Progesterone Regulation of Normal and Breast Cancer Cells 3

2. ESTROGEN AND PROGESTERONE RECEPTORS 7

2.1 Estrogen Receptors (ER)

2.2 Progesterone Receptors (PR) 11

3. MECHANISMS OF ER ACTION 14

3.1. Mechanism of Ligand-Dependent ER Activation 14

3.1.1. Estrogen Action $\quad 14$

3.1.2. Antiestrogen Action 17

3.2. Mechanism of Ligand-Independent ER Activation 20

4. ENDOCRINE MODULATORS AND BREAST CANCER 24

$\begin{array}{ll}4.1 \text { Xenoestrogens } & 24\end{array}$

4.2 Estrogenic Drugs and Acetaminophen 28

4.3 Acetaminophen 29 
4.3.2 Dosage and Use 30

4.3.3 Acetaminophen Studies. Estrogenic/antiestrogenic activity 31

5. EXPERIMENTAL MODELS FOR STUDYING THE NORMAL AND $\begin{array}{ll}\text { CANCEROUS BREAST } & 34\end{array}$

5.1 In Vitro Models 34

5.1.1 Breast Cell Cultures Advantages and Disadvantages 34

5.1.2 Normal Breast Cells in Culture 36

$\begin{array}{ll}\text { 5.1.3. Breast Cancer Cells in Culture } & 37\end{array}$

5.2. In Vivo Experimental Models 40

6. RESEARCH PROJECT OBJECTIVES 42

CHAPTER II. MATERIALS AND METHODS 44

1. Materials 44

2. Methods 45

2.1 Cell Culture $\quad 45$

$\begin{array}{ll}2.2 \text { Experimental Design } & 47\end{array}$

2.3 Endpoints in Vitro 48

2.4 Endpoints in Vivo

2.5 Statistics $\quad 58$

CHAPTER III. RESULTS

3.1 Acetaminophen Effects on Breast Cancer Cells in Culture 59

3.1.1 ${ }^{3} \mathrm{H}$-Thymidine Incorporation $\quad 60$ 
3.1.2 Percent S Phase Cells $\quad 65$

3.1.3 Cell Numbers $\quad 67$

3.1.4. Acetaminophen Induces ${ }^{3} \mathrm{H}$-Thymidine Incorporation under Other Dosing

$\begin{array}{ll}\text { Regimens } & 69\end{array}$

3.2. Cytotoxicity 71

3.3. Mechanisms of Acetaminophen-Induced Proliferation 71

3.3.1 T47D variants $\quad 71$

$\begin{array}{ll}\text { 3.3.2 Antiestrogen Studies } & 75\end{array}$

3.3.3 ER Binding Assays $\quad 83$

3.3.4 Acetaminophen Isomers Studies $\quad 85$

$\begin{array}{ll}\text { 3.4 Metabolism Studies } & 88\end{array}$

3.5 In Vivo Data 90

3.6 Data Summary 92

CHAPTER IV. DISCUSSION 95

$\begin{array}{ll}\text { REFERENCES } & 115\end{array}$

$\begin{array}{ll}\text { CV } & 135\end{array}$

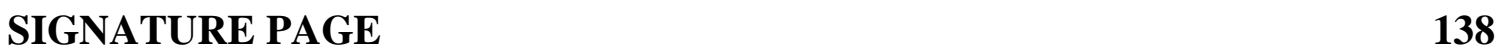




\section{LIST OF FIGURES}

Figure 3.1. Chemical Structures of Selected Xenoestrogens and of Acetaminophen 59

Figure 3.2. Effects of Acetaminophen on ${ }^{3} \mathrm{H}$-Thymidine Incorporation into DNA in estradiol-responsive ( $\mathrm{ER}+/ \mathbf{P R +})$ human breast cancer cells 60

Figure 3.3. Effects of Acetaminophen on DNA Synthesis in Estradiol-Nonresponsive (ER-/PR-) Human Breast Cancer Cells 63

Figure 3.4. Effects of Acetaminophen on DNA Synthesis in Normal Breast, ER-/PRHMEC cells 64

Figure 3.5. Effects of Acetaminophen on \% $\mathrm{S}$ phase Cells in ER+ Human Breast Cancer Cells 65

Figure 3.6. Effects of $0.1 \mathrm{mM}$ Acetaminophen on T47D Cell Proliferation 68

Figure 3.7. Acetaminophen Stimulates ${ }^{3}$ H-Thymidine Incorporation into DNA under a 1 Dose/3 Days Dosing Regimen in MCF7 Cells and T47D Cells but not

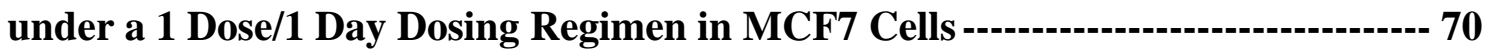

3.8. Effects of Acetaminophen on T47Dco, T47DYA and T47DYB Cells 73

Figure 3.9. Effects of ICI 182780 on Acetaminophen and Estradiol-Induced \% S Phase MCF7 Cells 76

Figure 3.10. Effects of 4-Hydroxytamoxifen on Acetaminophen and Estradiol-

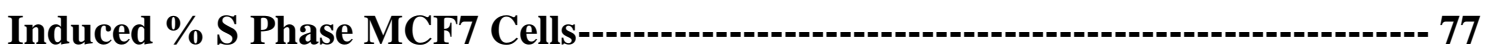

Figure 3.11. Effects of ICI 182780 on \% S Phase MDA-MB-231 Cells ----------- 78 
Figure 3.12. Effects of ICI 182780 and 4-Hydroxytamoxifen on Acetaminophen-

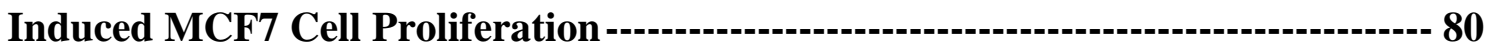

Figure 3.13. Effects of ICI 182780 and 4-Hydroxytamoxifen in Acetaminophen-

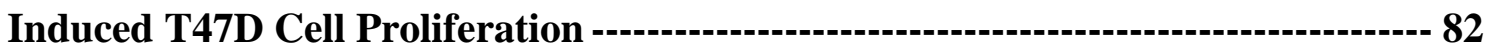

Figure 3.14. Acetaminophen does not Compete with Estradiol for Binding Estrogen

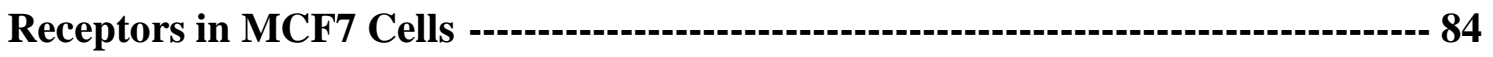

Figure 3.15. Effects of Acetaminophen Positional Isomers on T47D and MCF7 Cell

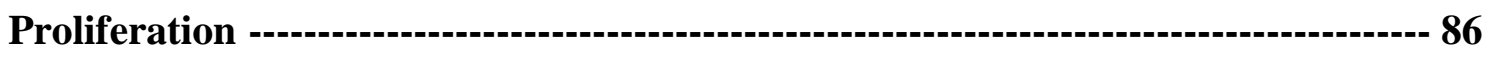

Figure 3.16. Acetaminophen metabolites from breast cancer cells microsomes --- 89

Figure 3.17. Acetaminophen Stimulates MCF7 Tumor Growth in Nude Mice ---- 90 


\section{CHAPTER I. INTRODUCTION}

\section{THE NORMAL AND CANCEROUS BREAST}

\subsection{General Aspects Related to the Normal and Cancerous Breast}

This project deals with breast cancer models. Therefore, some background is provided about the anatomy and physiology of the breast, and a classification of types of breast cancer according to their anatomical origin is included as well. Under normal circumstances, the breast in females fulfills vital functions in infant nutrition. The breast is located in the hypodermis of the anterior thoracic wall and consists of 15 to 20 lobes of glandular tubuloalveolar tissue, fibrous connective tissue connecting the lobes, and adipose tissue between the lobes. The epithelium is organized as a branching duct system terminating, when fully developed, in secretory ductules and alveoli. Subcutaneous fat and adipose tissue account for most of the breast mass in the non-lactating state. When the normal breast undergoes abnormal changes in physicochemical composition, structural, and functional changes, various diseases of the breast can result, including cancer. For example, many cancers involve abnormalities of ducts and alveoli. Accordingly, some breast cancers are classified according to their origin in the breast as ductal or lobular, and according to their invasive potential as noninvasive or invasive. While $80 \%$ of breast carcinomas are ductal invasive, intraductal carcinomas constitute 10-15\%, lobular, 5-7\%, and special types, 3-5\%. Models of breast cancer used in this study represent some of the most frequently encountered 
types of breast cancer.

Breast cancer is thought to be a multi-factorial disease, involving genetic, environmental, hormonal, and dietary factors, but its precise etiology is not known. While known risk factors can account for certain breast cancers, most are caused by yet undetermined factors. Models of breast cancer development propose that series of genetic changes contribute to the dynamic process of carcinogenesis (Boone et al., 1993) and accumulation of genetic changes is thought to participate in the evolution of malignancy. The carcinogenesis sequence is viewed as starting with tissue of normal appearance, followed by changes that lead to hyperplasia and dysplasia, with the most severe forms being difficult to distinguish from carcinoma in situ (Keloff et al., 1994). Some of the main forces driving the carcinogenic process have been characterized as mutagenesis and mitogenesis. If cancer escapes control, advanced metastatic stages often lead to death. Despite better means of preventing and treating breast cancer, one in eight US women will still develop breast cancer during her lifetime (Feuer et al., 1993). In fact, mortality rates from breast cancer are second only to lung cancer. Given these considerations, it is important to better understand the dynamics of aberrant proliferation involved in breast cancer. 


\subsection{Estrogen and Progesterone Regulation of Normal and Breast Cancer Cells}

Sex steroid hormones include estradiol and progesterone, and these hormones regulate normal breast cells and some cancerous breast cells that have both estrogen and progesterone receptors $(\mathrm{ER}+\mathrm{PR}+)$. Normal physiologic processes regulated by estrogen and progesterone include reproduction, embryo maturation, and sexual differentiation. These hormones can also affect some pathological processes, including some breast cancers. Because we have used estradiol as a positive control in our studies of normal and breast cancer cells, some background regarding how estradiol regulates breast cells under normal circumstances is given below.

Synthesis. The major estrogens produced by women are estradiol (most abundant and potent), estrone, and estriol. Estrogens are produced by females primarily in ovaries and by males primarily in testes. While the ovary is the primary source of estradiol in premenopausal women, the adrenal gland can synthesize estrogens in postmenopausal women and in men. Other estrogen-producing tissues include fat, hair follicles, liver and skeletal muscle. These tissues convert circulating androstenedione and testosterone (secreted by testes) into estrogens.

The other hormone that can act in concert with estrogen to regulate estrogen-responsive cells in vivo is progesterone. Progesterone is the most important natural progestin. Like estrogen, progesterone is produced in both females and males. In females it is secreted by corpus luteum 
primarily during the second half of the menstrual cycle and by placenta. In males testes secrete progesterone. It is also synthesized by the adrenal cortex in both sexes.

Both estrogen and progesterone are synthesized from cholesterol precursors with progesterone preceding estrogen formation in the synthetic path. A variety of enzymes catalyze these synthetic reactions. Synthesis and release are regulated by the hypothalamus-pituitary axis. Gonadotropin releasing hormone $(\mathrm{GnRH})$ from the hypothalamus regulates release of leutinizing hormone (LH) and follicle stimulating hormone (FSH) from anterior pituitary which in turn regulate sex hormones that feedback at the level of hypothalamus or pituitary. Sex steroids are metabolized by liver and other target organs and are excreted as conjugates via kidney and to a lesser extent via intestines.

Plasma estradiol levels. In our studies 3nM estradiol was used as positive control. These levels correspond to $\sim 816 \mathrm{pg} / \mathrm{ml}$ and reflect physiologic levels of estradiol achieved during early stages of pregnancy. To provide context for how these estradiol levels compare to estradiol levels during other stages of a woman's life, a more detailed description of estradiol level fluctuation with age is included below. In girls before 9-10 years of age, plasma estradiol levels are approximately $5 \mathrm{pg} / \mathrm{ml}$ (Berne and Levy, 1993). With onset of puberty, between ages 11-15, as ovarian secretion commences, budding of breasts coincides with increases in plasma estradiol levels to approximately $50 \mathrm{pg} / \mathrm{ml}$ (Berne and Levy, 1993). During ages 13-15, plasma estradiol 
levels rise to approximately $120 \mathrm{pg} / \mathrm{ml}$ (Berne and Levy, 1993). In premenopausal women estradiol levels are as follows: during the early follicular phase, $\sim 50 \mathrm{pg} / \mathrm{ml}$, late follicular phase, 350-500 pg/ml, and middle luteal $200 \mathrm{pg} / \mathrm{ml}$ (Berne and Levy, 1993). During pregnancy, estradiol levels increase to $\sim 16 \mathrm{ng} / \mathrm{ml}$ at the end of pregnancy. At menopause estradiol levels become $\sim 10-20 \mathrm{pg} / \mathrm{ml}$ (Berne and Levy, 1993).

Effects. In general, the effects of sex hormones are strictly dependent on life stage and celltype. Production of estrogens and progesterone by ovaries at puberty stimulates initial growth of mammary gland. Estrogen stimulates proliferation of ductal epithelial, myoepithelial and stromal cells of the breast. Progesterone together with estrogen initiates formation of secretory acinar components at distal aspects of ductules. With menarche, the cyclical estrogen and progesterone increase and further stimulate proliferation of ducts and formation of lobules. Progesterone and estrogen also stimulate proliferation of connective tissue that subsequently replaces adipose tissue and provides support for the developing ducts. In addition, ovarian steroids stimulate proliferation of adipose tissue and enhance proportional enlargement and pigmentation of areola. During pregnancy, the mammary glands undergo dramatic proliferation and development. Placenta and corpus luteum continuously increase overall estrogen and progesterone levels further stimulating proliferation and breast development. Alveolar development becomes prevalent, then cell proliferation ultimately declines and alveolar hypertrophy replaces proliferation. After menopause, mammary glands involute. The secretory cells of alveoli and connective tissue eventually degenerate, and stromal cells and collagen fibers decrease in 
numbers.

Estrogens are stimulatory not only to the normal breast at specific developmental stages but also to some breast cancer cells. Moreover, estrogenic hormones may play multiple roles in neoplastic progression as carcinogens, and as growth promoters. For example, estrogens are known to favor DNA damage through promotion of free radicals and, thus, may be involved in tumor initiation (Ciocca and Fanelli, 1997). But they have been mainly implicated in tumor promotion because of their mitogenic/proliferative activity (Ciocca and Fanelli, 1997). Normally, target breast cells have proper negative feedback control such that estrogenic stimulation does not promote carcinogenesis. However, increased exposure to estrogens/xenoestrogens increases the likelihood that normal cellular controls become altered (Ciocca and Fanelli, 1997). 


\section{ESTROGEN AND PROGESTERONE RECEPTORS}

\subsection{Estrogen Receptors (ER)}

Some breast cancer cell types used in these studies contain estrogen and progesterone receptors $(\mathrm{ER}+/ \mathrm{PR}+$ cells). These cells include $\mathrm{MCF} 7, \mathrm{~T} 47 \mathrm{D}$, and ZR-75-1 cells. Other types of breast cancer cells used in these studies, for example MDA-MB-231 cells, are classified as ER/PR- cells. Therefore, some background about ERs and PRs is given below. Two main ER subtypes have been described: $\alpha$, the classical receptor and $\beta$, only recently reported (Kuiper et al., 1996 and Mosselman et al., 1996). At a subcellular level, ERs are found predominantly in nucleus but also in cytoplasm and membranes. At tissue level, some estrogen-responsive tissues contain only $\alpha$, others only $\beta$, and yet others, both subtypes (Kuiper et al., 1997). It is possible that different tissue distributions of ERs as well as homo- or hetero-dimer formation may account for different types of regulation and tissue/cell-specific functions.

In the ER+/PR+ cells used in these studies, both ER $\alpha$ and $\mathrm{ER} \beta$ are present. More is known about the classic ER $\alpha$ than about the newly discovered ER $\beta$. ER $\alpha$ is a $66-\mathrm{kDa}$ protein composed of 595 amino acids. It has 6 structural domains (A at the $\mathrm{NH} 2$ terminus through $\mathrm{F}$, at the $\mathrm{COOH}$ terminus). Domain A spans amino acids 1-38; B, 38-180; C, 180-263; D, 263-302; E, 302-553; $\mathrm{F}, 553-595$. The ER $\alpha$ has two activation functions, AF1 in domain B and AF2 in domain E. In most estrogen-responsive cells, AF1 and AF2 function synergistically to activate estrogen- 
responsive gene transcription induced by pure agonists. Partial agonists/antagonists generally use only one of these activation functions (Katzenellenbogen et al, 1997). However, depending on the cell context and type of ligand/signal, AF1 and AF2 may act synergistically or independently (Smith, 1998) and so, the activities of AF1 and AF2 vary with cell type. Furthermore, AF1 is considered the basal activation function, while AF2 found in the ligand binding domain is considered ligand-inducible (Smith, 1998). The DNA binding domain (C) has two Zn fingers in which cysteine residues are coordinated to $\mathrm{Zn}$ ions. Region $\mathrm{D}$ is involved in binding chaperone proteins and in nuclear recognition. Region $\mathrm{E}$ is involved in ligand binding, heat shock protein binding, dimerization, and transcription activation (AF2 function). The last domain, F, modulates transcriptional activation (Smith, 1998).

ERs are regulated in part by changes in phosphorylation. The ER $\alpha$ receptor is a phosphoprotein that has 5 critical phosphorylation sites Ser 104, 106, 118, 167 and Tyr 537 (Smith, 1998). Mutations in these phosphorylation sites can modulate transcriptional activity of $\mathrm{ER} \alpha$, thwarting receptor function (Smith, 1998).

ER $\alpha$ and $\beta$ are differentially distributed in various estrogen-responsive tissues, suggesting different organ-specific roles for different combinations of ER subtypes. The distribution of ERs in humans is consistent with that in animals. For example, human ER $\beta$ was detected in testes (seminiferous epithelium, developing spermatids, stroma of cortex, blood vessels of medulla), 
prostate (epithelium of secretory alveoli), ovary (granulosa cells in humans have only $\beta$ ), and uterus (Bhat et al., 1998; Enmark et al., 1997; Mosselman et al., 1996). In addition, studies conducted in midgestational human fetus by Brandenberger et al. (1997) have shown that mRNA for ER $\alpha$ was most abundant in uterus, and less abundant but present in ovaries, testis, skin, and gut. Levels of ER $\beta$ were higher than levels of ER $\alpha$ mRNA in fetal ovaries, testes, adrenals and spleen. In uterus, ER $\alpha$ levels were higher than $\mathrm{ER} \beta$ mRNA levels. $\mathrm{ER} \beta$ mRNA was moderate to low in thymus, pituitary, skin, lung, kidney and brain cortex of midgestational human fetus (Brandenberger et al., 1997). The presence of ERs of either one or both subtypes in these tissues is believed to reflect distinct physiologic functions of these receptors within those tissues. However, such functions are not completely understood.

While it was known for some time that the classic ER $\alpha$ is important in physiologic processes regulating the normal breast and in breast cancer, with the discovery of ER $\beta$, a possible role for $\mathrm{ER} \beta$ in human breast cancer and in other cancers has emerged as well. For example, Pedeutour et al. (1998) noted that the human ER $\beta$ gene is located in a region frequently rearranged in uterine leiomyomata and other benign tumors, including pulmonary chondroid hamartomas and endometrial polyps, suggesting a potential role for ER $\beta$ in these diseases. Other researchers (Enmark et al., 1997) noted that regions of chromosome 14 are also rearranged in kidney neoplasms and genes involved in early onset of Alzheimer's disease. Dotzlaw et al. (1997) and Lu et al. (1998) detected ER $\beta$ in several human breast tumor biopsies and several human breast 
epithelial cells. Consistent with the studies just described, Vladusic et al. (1998) identified ER $\beta$ in some breast tumors and cells. For example, a variant of ER $\beta$ is coexpressed with wild-type $\mathrm{ER} \beta$ in the ER $\alpha-/ \mathrm{PR}$ - human breast cancer cell line MDA-MB-231 and in malignant breast tumor specimens. This variant, however, was not detected in the tested normal breast tissue. The ER $\beta$ variant had 139 bp deleted in the hormone-binding domain, corresponding to exon 5 of ER $\alpha$. The ER $\beta$ variant protein was predicted to lack part of the hormone-binding domain and to bind estradiol with lower affinity than the wild-type ER $\beta$ protein. 


\subsection{Progesterone Receptors (PR)}

Breast cancer cells with various complements of ER and PR were used in this study to differentiate between acetaminophen-induced effects mediated by ER and by PR. PR exhibits properties and functions different from ER as briefly discussed below. Unlike the ER, a single gene located on chromosome 11 (Graham et al., 1989) encodes two forms of PRs, designated PRA and PRB. Like ERs, the distribution of PRs varies and some tissues/cells express only one isoform or both. For example, in uterine fibroids PR levels are higher than in adjacent normal tissue (with PRA greater than PRB). In addition, a significant number of tumors have high PRA and low PRB levels. And, as with ERs, PRA and PRB vary with life stage and menstrual cycle. For example, both isoforms are expressed highly in the periovulatory phase of the cycle with PRA higher than PRB. Moreover, PRB is maximally expressed during days 14-16 of menstrual cycle and minimally expressed at beginning and end of cycle. PRA $(94 \mathrm{kDa})$ is an N-terminally truncated form of PRB which exists as triplets (114, 117, and $120 \mathrm{kDa}$ ) (Sheridan et al., 1989; Keightley, 1998). When analyzed by Western blotting, PRs are initially seen as single B bands of $114 \mathrm{kDa}$ and a single A band of $94 \mathrm{kDa}$ (Sheridan et al., 1989). The mature B-triplets seen as three bands on Western blots form 6-10 h later by post-translational phosphorylation at sites restricted to the B-proteins (Sheridan et al., 1989). This slow maturation is not required for PR activation to hormone binding states, however, since A- and B-receptors less than 15 min old respond to progestins by undergoing transformation and nuclear binding accompanied by a rapid secondary phosphorylation common to both proteins (Sheridan et al., 1989). The two isoforms differ functionally when occupied by agonists or antagonists, and the unique 164-amino acid, B- 
upstream segment (BUS) is in part responsible for the functional differences between the two isoforms (Sartorius et al., 1994). The B-isoform of human progesterone receptors contains three activation functions (AF3, AF1, and AF2), two of which (AF1 and AF2) are shared with the Aisoform (Hovland et al. 1998). AF1 is located in the $\mathrm{N}$ terminus in a 90 -amino acid segment just up-stream of the DNA-binding domain (DBD) and nuclear localization signal (NLS), and AF2 is located in C terminus in the hormone-binding domain. BUS is a highly phosphorylated domain, and contains the serine residues responsible for the PRB triplet protein structure. AF3 in PRB is located within BUS and requires a functional DBD. Depending on the promoter or cell tested, AF3 can activate transcription autonomously, or it can functionally synergize with AF1 or AF2. Autonomous AF3 function may explain the unexpected transactivating actions of antiprogestinoccupied PRB, an issue of importance in hormone-resistant breast cancers and in tissue-specific agonist-like effects of hormone antagonists. B-receptors are usually stronger transactivators than A-receptors due to transcriptional synergism between AF3 and one of the two downstream AFs (Hovland et al., 1998). Nevertheless, both forms bind progesterone and are transcriptionally active (Vegeto et al., 1993). However, PRA expression is dominant over PRB (Keightley, 1998).

Like in the case of ERs, phosphorylation is a major means of regulating PRs. Human progesterone receptors (PRs) are phosphorylated at multiple serine residues basally; they become hyperphosphorylated by hormones (Takimoto et al, 1992). Compared to PRA, PRB contains three extra phosphorylation sites in its $\mathrm{N}$ terminal domain (Zhang et al., 1994), one of which is phosphorylated by casein kinase on Ser 81 (Zhang et al., 1994) and the other on Ser 162 (Zhang 
al., 1997).

Since PRB has been known long before ERbeta, the importance of homo and heterodimer formation in PR action has long been recognized. Like ERs, PRs can exist as hetero or homodimers and there are specific cell types that express only PRA, only PRB homodimers or PRA-PRB heterodimers. Both ER and PR DNA binding involve dimerization in most cases but PR transformation also involves dissociation and unmasking of A subunit with greater DNA affinity. In both ER and PR action, the pattern of transcriptional activation depends on the particular combination of homo/heterodimer receptor complexes. Liganded PRA and PRB can suppress estradiol-stimulated ER activity and PRA also suppresses PRB (so, PRA is a stronger repressor). The magnitude of PR suppression of ER response depends on which PR isoform is predominant and cell type (Katzenellenbogen, 1996). PRB under certain conditions can switch from recognizing an antagonist as an antagonist to mis-recognizing an antagonist as an agonist. In contrast, PRA does not display such undesired switch activity and strongly represses not only PRB but also other members of the steroid receptor family such as androgen receptors and glucocorticoid receptors (Vegeto et al., 1993). Liganded PRA and PRB can each suppress estradiol-stimulated ER activity with the magnitude of repression dependent on the PR isoform, progestin ligand, promoter, and cell context/type (Katzenellenbogen, 1996). The clinical relevance is that in ER+/PR+ tissues antiprogestins (e.g., RU486) can antagonize not only the PRB-mediated transactivation but also ER-mediated transactivation via PRA inhibition of ER (Keightley, 1998). 


\section{MECHANISMS OF ER ACTION}

\subsection{Mechanism of Ligand-Dependent ER Activation}

\subsubsection{Estrogen Action}

The mechanism of both estrogen and antiestrogen action involve ERs. The phosphorylated ERs can function as inducible, ligand dependent or independent transcription factors. ER function appears to be controlled by two key regulators: (1) cell cycle specific and nonspecific kinases and phosphatases that dictate critical phosphorylation changes and (2) Hsp90 heterocomplex/transcriptional complexes (Katzenellenbogen et al., 1996; Weigel and Zhang, 1998; Lieberman, 1997).

ERs undergo activity cycles. According to Lieberman (1997), a cycle includes several steps. (1) ER associates with Hsp90 (ER priming). (2) Hsp90 heterocomplex dissociates from ERs followed by release of dimers or release of monomers with subsequent dimerization. (3) ERs are transported to nucleus. (4) If ligand is present, it binds the ER; then $\mathrm{Zn}$ fingers become exposed and the ER-ligand binds the DNA estrogen response element directly or indirectly, via other nuclear proteins such as SP1 proteins or SRC-1, ERAP, or A1B1 coactivator proteins. (5) Estrogen-responsive gene transcription occurs. (6) ERs dissociate from the transcription machinery. (7) ERs reassociate with the Hsp90 heterocomplex, then deactivate and degrade 
(Lieberman, 1997). In target cells, during step 1, Hsp90 heterocomplexes block inappropriate ER-DNA interactions and at the same time prime ERs for incoming signals, helping them to become functional once signal has reached its target. ER-ligand complexes then become hyperphosphorylated, and complete step 3, moving to the nucleus, aided by Hsp70. They reach the nuclear membrane, Hsp70 dissociates and ligand-ER complexes enter into the nucleus. Step 3 in the classical mechanistic model involves ER dimerization that must occur for ER to complete step 4 (DNA binding); however, there are also reports of ERs binding as monomers or multimers (Lieberman, 1997). During step 4, ligand binds to ER. Occupancy of $5 \%$ of the total ER population is sufficient for strong agonists, such as $17 \beta$-estradiol to increase estrogen-dependent gene transcription and cell proliferation (Ciocca and Fanelli, 1997). ER-ligand complexes can bind to a transcriptional complex made of nuclear protein and bind indirectly to the estrogen response element on DNA. Alternatively, the ER-ligand complex can bind directly to the DNA response element (Lieberman, 1997) and some papers indicate that nuclear Hsp90 also contributes to DNA binding (Inano et al., 1994). Two DNA Zn fingers participate in dictating the association of the ER with the estrogen response element of specific genes. As mentioned, interaction of ER with the estrogen response element can occur either directly or indirectly, mediated by transcriptional complexes (Katzenellenbogen et al., 1997). Subsequent to ligand binding, ligand-ER complexes change conformation and dissociate from Hsp90 in cytoplasm or nucleus (not known). Further, depending upon whether the ligand is an agonist or an antagonist and depending upon concentration, step 5 ensues with activation or suppression of estrogenresponsive gene expression (e.g., PR gene induction). The net effect is increased/decreased protein product (e.g., PR protein) and stimulation/suppression of proliferation 
(Katzenellenbogen, 1997). One cycle ends with step 7, culminating in ER degradation and a new cycle begins with ER resynthesis.

The most potent estrogen, $17 \beta$-estradiol, initially upregulates both ER and PR synthesis, then high PR levels downregulate both ER and PR by mechanisms not well understood. It has been suggested that long-term (days) exposure of ER+ cells to agonists leads to activation by ligand of both the ligand-dependent and the ligand-independent pathways (Castaño et al., 1998). This occurs because long-term agonists can stimulate production of growth factors, e.g., epidermal growth factor (EGF), transforming growth factor $\alpha$ (TGF $\alpha$ ), insulin-like growth factor (IGF-I) and their receptors (Smith, 1998). The cells, in turn, exert positive feedback on themselves or neighboring cells and activate the MAP kinase pathway. Alternatively, estradiol may simply act on membrane receptors (Castaño et al., 1998). Thus, the mechanism of ER $\alpha$ activation is complex and complexity is added in cells like the ER+ breast cancer cells used in this research in which ER $\alpha$ coexists with $\mathrm{ER} \beta$ or in cells with only $\mathrm{ER} \beta$. 


\subsubsection{Antiestrogen Action}

Antiestrogens are used in both clinical (for example for treatment of breast cancer) and in experimental situations to determine if compounds with estrogenic activity act via ERs. Antiestrogens are traditionally known to compete with estrogen for binding to ERs and, thus, block estrogen-responsive gene transcription and cell proliferation. However, there is more to antiestrogen action than this simplified mechanistic view. This will be considered in more detail in the next section. In this section some aspects that distinguish partial from complete antiestrogens are considered. The mechanisms of action of partial and complete antiestrogens have similarities and differences. For example, both partial (e.g., tamoxifen) and complete (e.g., ICI 182,780) antiestrogens induce changes in the conformation of the ER. However, only complete antiestrogens also decrease the levels of ERs by decreasing receptor half-life and increasing receptor degradation (Katzenellenbogen et al., 1997). It is interesting to note that a chemical that appears to act in a similar manner (by changing steroid receptor conformation and increasing its degradation) is geldanamycin. This compound specifically inhibits Hsp90 heterocomplex function and thus the function of the steroid receptors associated with it (Neckers et al., 1998). Such a parallel suggests that the Hsp90 heterocomplex or other ER interacting proteins may be additional/alternative targets of pure antiestrogens. For example, ICI182780 alters or blocks the stress pathway via MAP kinase, and blocks Ser 118 phosphorylation of ER (Castaño et al., 1998). This may occur by ICI 182780 interfering with the dissociation of accessory proteins blocking access of MAP kinase to this site (Castaño et al., 1998). Thus, antiestrogens such as ICI182780 are more effective than tamoxifen because they block the 
receptor, like tamoxifen, leading to decreased transcription activation, but they may also destabilize the interaction of ER with critical regulatory proteins involved in transcription regulation and in ER proteolysis, such as the Hsp90 heterocomplex. Such events involve increased receptor turnover due to impaired dimerization that results in impaired function of ERs (DeCupris and Favoni, 1997). Another difference between partial and complete antiestrogens is that, in contrast to partial antiestrogens, complete antiestrogens have a higher affinity for ERs, being up to 100 fold more potent than tamoxifen (DeCupris and Favoni, 1997).

Many compounds that mimic estrogen action or inhibit it, bind to ERs but the affinity of various agonists and antagonists that bind to the different ER subtypes varies. Some examples included binding profiles of antiestrogens used in the studies described in this dissertation are summarized below. Initially, it was reported that ER $\beta$ transactivation by $17 \beta$-estradiol is similar to $\mathrm{ER} \alpha$ and that the $\mathrm{ER} \alpha$ antagonist, ICI-164384 is a potent antagonist for $\mathrm{ER} \beta$ as well (Mosselman et al., 1996). Subsequently, some differences were noted between the binding affinities of ligands to the different ERs (Kuiper et al., 1997). For example, the affinity for 17 $\beta$-estradiol of ER $\beta$ was reported to be slightly lower than for $E R \alpha$ with $K_{d \beta}=0.5 \mathrm{nM}$ and $K_{d \alpha}=$ 0.2 nM, respectively (Tremblay et al., 1997; Kuiper et al., 1998). Consistently, antiestrogens like 4-hydroxytamoxifen, ICI182780, and EM-800 inhibited estradiol-dependent transactivation in other studies (Tremblay et al., 1997). However, 4-hydroxytamoxifen displayed partial agonistic activity with only with ER $\alpha$ not with $\mathrm{ER} \beta$ (Tremblay et al., 1997). Other studies indicated that in rat the affinity of $17 \beta$-estradiol for $E R \beta / \alpha$ subtypes varied, with $\mathrm{K}_{\mathrm{d} \beta 2}=5.1 \mathrm{nM} ; \mathrm{K}_{\mathrm{d} \alpha}=0.19 \mathrm{nM}$; 
and $\mathrm{K}_{\mathrm{d} \beta 1}=0.14 \mathrm{nM}$ (Petersen et al., 1998). In addition, all known estrogenic agents, including physiological estrogens (estrone and estriol), plant and environmental estrogens (genistein, coumestrol, bisphenol A, methoxychlor), and pharmacological agents (tamoxifen, 4hydroxytamoxifen) competed with estradiol for binding to both ER $\beta 1$ and ER $\beta 2$. However, differences between ER $\beta$ subtypes were found. For example, genistein bound preferentially to ER $\beta 1$ compared to ER $\beta 2$ (Petersen et al., 1998). In contrast, 4-hydroxytamoxifen bound equally well to both receptors (Petersen et al., 1998). Barkhem et al., 1998 confirmed that some compounds prefer to bind to $\mathrm{ER} \beta$ over $\mathrm{ER} \alpha$ or vice versa while others can bind to both to $\operatorname{ER} \beta$ and ER $\alpha$ equally well. For example, $17 \alpha$-ethynyl 17 $\beta$-estradiol, has an ER $\alpha$-selective agonist potency while $16 \beta 17 \alpha$-epiestriol has an ER $\beta$-selective agonist potency. Genistein has ER $\beta$ selective affinity and potency but ER $\alpha$-selective efficacy. Tamoxifen, 4-OH-tamoxifen, raloxifene, and ICI 164384 are partial agonists/antagonists at ER $\alpha$ but pure antagonists at ER $\beta$. In addition, raloxifene displayed ER $\alpha$-selective antagonist potency, in agreement with its ER $\alpha$ selective affinity. However, although ICI 164384 showed ER $\beta$-selective affinity, it had a similar potency to antagonize the effect of $17 \beta$-estradiol in both ER $\alpha$ - and ER $\beta$-specific reporter cell lines. These data suggest that ER $\beta$ and ER $\alpha$ have different ligand binding profiles depending on whether the ligand is a partial or total agonist/antagonist. 


\subsection{Mechanism of Ligand-Independent ER Activation}

Alternative ligand-independent mechanisms of ER activation are relatively newly recognized. Thus, much less is known about it than about the classical ligand-dependent activation of ERs. Ligand-independent transcriptional activation is dependent on cell type, on ER type (wild type or mutant), the complement of proteins present in a certain cell-type, corepressors/co-activators, and the effects of signal transduction on levels and interactions of these proteins. A variety of signals such as growth factors (epidermal growth factor, EGF; insulin growth factor, IGF-1; Her2/neu), neurotransmitters (dopamine), second messengers (cAMP) and stress, can act via membrane receptors and can activate ERs in turn (Katzenellenbogen et al. 1997; Castaño et al., 1998). For example, dopamine or dopamine agonists stimulate ERdependent gene transcription by acting on D1 receptors in plasma membrane (Smith, 1998). Other examples include protein phosphatase inhibitors, such as okadaic acid, or PKA activators, such as chlolera toxin that can ligand-independently stimulate ER-mediated transcription (Smith, 1998). Thus, in absence of ligand, agents that act on ER regulatory enzymes and that specifically activate protein kinases or inhibit protein phosphatases can stimulate ER-dependent gene transcription (Smith et al., 1998). In addition, estradiol and protein kinase activators can synergistically stimulate ER-mediated transcription. This occurs by interaction with target components of transcriptional complexes via phosphorylation changes or via interactions with proteins that modulate ER during transcriptional activation (Katzenellenbogen, 1996). Additional examples include growth factors that can activate ERs by pathways that cross the ER pathway. For example EGF acting through its own receptors in cell membranes can activate ERs. 
Transforming growth factor alpha, TGF $\alpha$, cAMP and IGF-1 actions can be mediated by ERs as well (Weigel and Zhang, 1998, Lee et al., 1999).

The ER can also become ligand independent in certain circumstances. For example, mutations at critical residues and partial to total deletion of the hormone-binding domain (thus the AF2 activation function) can render ERs constitutively active. This suggests that only the AF1 is required for ERs to have constitutive action or action induced by growth factor signaling cascades.

As mentioned before, the ability of the receptor to induce transcription depends in part on the proteins with which the receptor interacts to induce transcription. It has been pointed out that two key regulators of this process are enzymes affecting phosphorylation changes and Hsp90 heterocomplexes. In the ligand-independent pathway, the growth factor (e.g., EGF) binds to its plasma membrane receptor, activates the MAP kinase cascade, and induces phosphorylation of Ser 118 on the ER. This facilitates ER transport to the nucleus and ER binding to transcription factors instead of binding directly to ERE, as occurs in the ligand-dependent case. This sequence leads to similar subsequent events as described in the ligand-dependent activation such as DNA and protein synthesis and proliferation (Castaño et al., 1998; Katzenellenbogen et al., 1997). These types of differences are thought to potentially account in part for the observed mixed 
agonist/antagonist activity of antiestrogens such as tamoxifen.

Antiestrogens can inhibit some ER-independent pathways as well. For instance, antiestrogens can block some growth factors that exert autocrine positive feedback on cell proliferation (Katzenellenbogen et al., 1997). They may also block some growth factor receptors (TGF $\alpha$, IGF-I) while they induce growth inhibitory factors (TGF $\beta$ ) and their receptors (Katzenellenbogen et al., 1997; DeCupris and Favoni, 1998). Some clinical antiestrogens such as tamoxifen are partial antagonists/agonists and, consequently, depending on cell type, they can act as antagonists in breast cancer cells but as agonists in endometrial cells and, thus, produce side effects (endometrial cancer). Additional effects of antiestrogens include inhibition of angiogenesis, induction of apoptosis and increase in tumor suppressor protein products of genes such as BRCA1 (Katzenellenbogen et al., 1997). Tamoxifen can also affect cellular function by binding to calmodulin or inhibiting PKC (DeCupris and Favoni, 1997). So, antiestrogens can inhibit cell growth and induce apoptosis independently of the ER in both ER+ and ER- breast cancer cell lines (DeCupris and Favoni, 1997).

One of the main differences between the ligand-dependent and ligand-independent activation is thought to be the differential phosphorylation of critical residues on ERs, with liganddependent activation leading preferentially to Ser 167 phosphorylation while ligand-independent phosphorylation involving Ser 118 phosphorylation (Castaño et al., 1998). However, whether 
such clear differences exist is still unclear (Weigel and Zhang, 1998). Furthermore, phosphorylation of Tyr 537 has also been implicated in ligand-independent activation of ER, especially in steps such as the release of Hsp90 from ERs (Castaño et al., 1998). Mutations in Tyr 537 create constitutively active ERs and in contrast to wild type ERs, these mutants can interact with coactivator proteins, such as SRC-1, in the absence of hormone. Thus the Tyr 537 and the adjacent amphipathic helix form a conformation-dependent interaction surface for coactivators (Smith, 1998). Tremblay et al. (1998) found, consistently, that mutations at Tyr 537 in ER $\alpha$ and at Tyr 443 in ER $\beta$ rendered constitutively active ERs. However, the ligand-independent transcriptional activity of all ER $\alpha$ and $\operatorname{ER} \beta$ mutants examined, was completely abolished by antiestrogens (EM-652, ICI 182,780, and 4-hydroxytamoxifen). Thus, a compound could mimic estradiol effects by altering for example ER phosphorylation, without actually binding ERs and antiestrogens would inhibit these estrogenic effects even though they are not directly mediated by binding to ERs. 


\section{ENDOCRINE MODULATORS}

\subsection{Xenoestrogens}

Xenoestrogens (also called estrogens, estrogenic xenobiotics, endocrine activators, modulators, or disrupters), are exogenous chemicals that modify normal estrogen functions in the body (Raloff, 1993). The definition of estrogenic chemicals is highly controversial mainly because many xenoestrogens are not total mimics of estrogen action but partial mimics or mimics of one or more but not all of estrogen responses. Xenoestrogens have stimulatory effects in various tissues. Stimulatory effects are direct effects manifested by xenoestrogens in estrogenresponsive, target tissues and cells by mimicry of estrogen actions. Normally, like estrogen (particularly estradiol, the main estrogen) xenoestrogens are able to induce the proliferation of different cells that are components of estrogen target organs. For example, proliferation can occur in lobular ducts and adipose tissue in breasts, in endometrium in uterus, in secretory epithelial and ciliated cells in fallopian tubes, or in squamous epithelial cells in vagina (Berne and Levy, 1992). Other stimulatory effects of xenoestrogens that mimic estrogen effects include induction of increased secretion of various proteins in breast, uterus, liver, and increased $\mathrm{Na}^{+}$ reabsorption in kidneys that leads to increased water retention in cervix (Berne and Levy, 1992). Absence or depletion of estrogens and xenoestrogens or presence of antiestrogens leads to inhibitory effects in estrogen-responsive tissues and cells. For example, depletion of estrogen at

menopause leads to bone loss (Vorherr, 1967). Overall, estrogenicity is the capacity of a xenoestrogen to induce estrogenic effects. 
Xenoestrogens are derived from various sources and can have different effects on different reproductive tissues. Natural xenoestrogens include plant components (e.g., genistein), mycotoxins (e.g., zeranol), or microbial intestinal faunas (e.g., enterolactone) (Roy et al, 1997); most appear benficial. Synthetic xenoestrogens include products of agriculture (e. g., some DDT metabolites), chemical industries (e.g., alkylphenols), food and drug industries (e.g., bisphenol A) (Roy et al., 1997); most appear detrimental. One possible explanation of the beneficial versus detrimental effects of natural versus synthetic estrogens has been suggested to be their different metabolism (Davis et al., 1997). For example, natural estrogens could be more easily metabolized than synthetic estrogens and the natural estrogens may be more extensively metabolized to 2-hydroxy estrogens that have primarily antiestrogenic/antiproliferative activity. On the other hand, synthetic estrogens may metabolize less extensively and /or may metabolize more extensively to 4-hydroxyestrogens that have primarily estrogenic/proliferative activity in some ER+ cells. Detrimental effects can occur in response to environmental xenoestrogen exposure in various non-mammalian species such as fish (White et al., 1994), reptiles (Guillette et al., 1994), and birds (Fry et al., 1987). Some unwanted effects include decreased reproductive capacities and feminization of males. $P$-nonylphenol, a biodegradation product of nonionic, ethoxylated detergent surfactants used in industrial applications, reaches levels of the order of $\mathrm{mg} / \mathrm{l}$ in sewage effluents and of the order of $\mathrm{ng} / \mathrm{l}$ in drinking water. Levels of this order of magnitude of $p$-nonylphenol and other alkylphenols detected in fish collected from polluted waters are weakly estrogenic (Soto et al., 1991). Polychlorinated biphenyls (PCB) disrupt 
endocrine function in various mammalian species (Birnbaum, 1994; Colborn et al., 1993; Bergeron et al., 1994; McLachlan et al., 1993). These include whales (Martineau et al., 1988) and seals (Reijnders, 1986).

Exposure of laboratory animals to xenoestrogens such as bisphenol A can induce gender related disorders (IARC, 1979). Bisphenol A, which leaches out from food packaging and plastic materials (Knaak and Sullivan, 1966; Krishnan et al., 1993; Brotons et al., 1905; Bond et al., 1980; Atkinson and Roy, 1995), produces adverse reproductive effects in rats and mice (Knaak et al., 1966; Bond et al., 1980; Atkinson and Roy, 1995). A possible association of bisphenol A with cancer of the hematopoietic systems of rats and mice is also likely (Ashby and Tennant, 1988). Other natural and synthetic xenoestrogens can cause different types of cancer, depending on the nature, strain, and species of the tested animal (IARC, 1979). Noble rats exposed to estrone develop breast cancer (Cutts, 1964). Other rats and mice exposed to diethylstilbestrol, estradiol, or estrone develop breast, bladder, ovarian, testicular, lymphatic, uterine, or prostatic tumors. Hamsters develop kidney and uterine tumors; rabbits develop endometrial tumors; and dogs develop ovarian and breast tumors (IARC, 1979). Currently, many of the effects of substituted p-phenols on non-aquatic animal species and humans are still unknown.

Although still controversial, recent laboratory and epidemiological studies lead to a growing concern that human cancer etiology may involve synthetic xenoestrogen exposure (Malone, 
1993). For example, exposure to dichlorodiphenyldichloroethane (DDE) or diethylstilbestrol (DES) may lead to breast cancer development (Safe, 1995; Malone, 1993). Daughters of women who took diethylstilbestrol during pregnancy had increased fertility problems (Herbst et al., 1992) and some developed breast cancer or a rare form of vaginal cancer (Marselos and Tomatis, 1992). Moreover, malformations appeared in both male and female offspring from females exposed to DES during pregnancy (Stillman, 1982). Other reproductive problems include sterility in male factory workers exposed to kepone (Guzelian, 1982), and higher risk of spontaneous abortion in female pharmaceutical workers exposed to estrogens (Taskinen et al., 1986).

From a mechanistic standpoint, xenoestrogens can mimic the action of estrogen very closely while many others may not mimic the mechanism of action of estrogen closely but may only mimic some of estrogen effects. For instance, diethylstilbestrol binds to ERs via the direct ligand-independent pathway and induces ER+ breast cancer cell proliferation. On the other hand, other compounds such as o, p'-DDT do not bind directly to estrogen receptors but stimulate ER+ breast cancer cell proliferation by acting on ERs indirectly, via ligand-independent pathways (Roy et al., 1997, Enan and Matsumura, 1998). 


\subsection{Estrogenic Drugs and Acetaminophen}

Some pharmaceuticals such as estradiol and diethylstilbestrol (estrogenic prototypes), quinestrol, chlorotrianisene, ethynylestradiol, equilenin, and mestranol (Roy et al, 1997) are estrogenic drugs. However, there are examples of drugs, such as cimetidine and digitalis, that, although not originally designed for estrogenicity, display this potential (Roy et al, 1997). Acetaminophen was first chosen for this study because it is one of the drugs not originally designed for estrogenicity but with potential for estrogenicity. Generally, xenoestrogens have diverse chemical structures and structure-activity correlations are difficult to establish (Raloff, 1993). However, a minimal chemical structure resemblance with estrogen appears to be sufficient for estrogenicity (Cunningham et al., 1997). The moiety that confers estrogenic activity to many xenoestrogens is the $p$-phenol moiety (Soto et al., 1991, Cunningham et al., 1997). Acetaminophen is a $p$-substituted phenol. Thus, because acetaminophen contains the $p$-phenol moiety, it may show some effects that are similar to those shown by estradiol in estradiol target cells (Cunningham et al., 1997). Furthermore, the choice of acetaminophen has other justifications besides a structure-activity correlation. Acetaminophen is a common analgesic and antipyretic. If shown to be estrogenic, it could impact certain individuals. A description of acetaminophen and some studies relevant to this project is included below. 


\subsection{Acetaminophen}

\subsubsection{Physicochemical Properties}

Acetaminophen has a multitude of names and is available in more than 800 combinations (Prescott, 1996). Its formula is C8H9NO2 and molecular weight 151.16. It is a white odorless crystalline powder with melting-point of $169-170.5^{\circ} \mathrm{C}$. It is soluble in water $(1: 70,1: 20$ at $\left.100^{\circ} \mathrm{C}\right)$, ethanol (1:7), acetone (1: 13), chloroform (1:50), glycerol (1:40), methanol (1: 10), propylene glycol (1:9) and solutions of alkali hydroxides. A saturated aqueous solution has a $\mathrm{pH}$ $\sim 6$. Dry, pure acetaminophen is stable to $45^{\circ} \mathrm{C}$. Humid conditions that cause hydrolysis to $p$ aminophenol, result in degradation and discoloration. It is slightly light sensitive in solution. It has a $\mathrm{pKa}=9.0-9.5$, a partition coefficient, $P c=6.237$ (octanol: $\mathrm{pH} 7.2$ buffer) and a protein binding fraction $\mathrm{Fb}=0.25$ (Prescott, 1996). 


\subsubsection{Dosage and Use}

Acetaminophen is available as $325-\mathrm{mg}$ or $500-\mathrm{mg}$ tablets. It is also available as $500-\mathrm{mg}$ gelatin capsules and as a mint-flavored liquid containing $500 \mathrm{mg} / 15 \mathrm{ml}$ solution. For children, drops $(80 \mathrm{mg} / 0.8 \mathrm{ml})$, chewable tablets $(80 \mathrm{mg})$, elixir $(160 \mathrm{mg} / 5 \mathrm{ml})$ and coated capsules (160 mg/capsule) are available (Prescott, 1996).

Acetaminophen is widely used as an analgesic and antipyretic drug. It is the preferred alternative analgesic-antipyretic to aspirin, particularly for patients with coagulation disorders, individuals with a history of peptic ulcer or who cannot tolerate aspirin, as well as for children. The conventional oral dose for adults is 500-1000 mg. Dosing may be repeated every $4 \mathrm{~h}$ as necessary, but the total daily dose should not exceed $4 \mathrm{~g}$. For children, the recommended dose is $10-15 \mathrm{mg} / \mathrm{kg}$; no more than five doses should be administered over $24 \mathrm{~h}$. Prolonged use (for more than ten days) is not recommended. The usual dose for rectal administration is equal to that for oral administration (Prescott, 1996). 


\subsubsection{Acetaminophen Studies. Estrogenic/Antiestrogenic Activity}

Acetaminophen has been studied in detail but most data relate to its hepatotoxic effects.

However, limited studies are reported on the interaction of acetaminophen with cells modulated by estrogen. Generally, literature indicates that acetaminophen has mostly an inhibitory effect on various cell types including those modulated by estrogen. However, it is important to mention that most of the studies that show inhibitory effects of acetaminophen in various systems use concentrations of acetaminophen that are well above concentrations considered toxic in humans (Prescott, 1996). When female rats were given $250 \mathrm{mg} / \mathrm{kg}$ acetylaminofluorene without or with acetaminophen at $11 \mathrm{~g} / \mathrm{kg}$ for 20 weeks, mammary tumors were seen in $14 / 20$ acetylaminofluorene-treated animals and in $7 / 20$ in acetaminophen plus acetylaminofluorene treatments. This indicates an antiestrogenic effect of acetaminophen on mammary tumors of these rats at the concentrations used (Weisburger et al., 1973). However, it is important to point out that acetaminophen metabolism in rats is completely opposite to acetaminophen metabolism in adult humans (Prescott, 1996). There is an additional study examining acetaminophen interactions with breast cells. Teicher et al. (1993) examined acetaminophen effects on murine EMT-6 mammary carcinoma cells in culture to determine if this drug modulated the effects of antitumor alkylators, and acetaminophen had no significant effect on alkylators. Another study showed that when acetaminophen was administered to rats in sub-therapeutic doses, it was found to inhibit intestinal carcinogenesis induced by dimethyl aminobiphenyl (Williams and Iatropoulos, 1997). 
Recent studies reported that daily acetaminophen use in humans decreased risk of ovarian cancer and decreased plasma estradiol levels (Cramer et al., 1998 a, b). In mice breeding studies, Reel et al. (1992) and Boyd et al. (1970) found that $1.43 \mathrm{~g} / \mathrm{kg} / \mathrm{day}$ acetaminophen reduced the number of litters per breeding pair, increased the percent abnormal sperm, and increased testicular atrophy. In other studies, acetaminophen concentrations (corresponding to toxic plasma levels achieved in humans) reduced progesterone production in cultured porcine granulosa cells (Haney et al., 1987). Acetaminophen inhibited estrogen-induced vitellogenin production in isolated trout liver cells at both acetaminophen levels that correspond to therapeutic and toxic plasma levels in humans (Miller et al., 1999). Acetaminophen 5-50 $\mu \mathrm{g} / \mathrm{kg}$ did not compete with estradiol for binding to mice uterine estrogen receptors, and it did not increase uterine weight, an estrogenic effect (Isenhower et al., 1986).

Acetaminophen was identified as a peroxisome proliferator in a 48-hour assay. In this assay, acetaminophen upregulated chloramphenicol acetyl transferase fusion construct to rat acetyl CoA oxidase stably transfected in a rat liver cell line (Lee et al. 1997). This induction suggested that acetaminophen played a role in cell proliferation and tumor progression. Acetaminophen (0.1-0.3 $\mathrm{mM}$ ) was also shown to enhance proliferation of lung carcinoma cells; it was suggested this effect occurred via alterations of membrane lipids (Schonberg and Skorpen, 1997). It is important to note that the latter two studies used relevant, pharmacological concentrations of acetaminophen. Overall, all of the studies mentioned in this section suggest acetaminophen displays a range of effects and it may act as an antiestrogen or an estrogen in some estrogenresponsive systems while it may have no effects in others. These effects depend on cell type, 
concentrations of acetaminophen used, and assay conditions. Moreover, some of the inhibitory effects of acetaminophen may be due to toxic effects. Prior to this project, there had been no reports of effects of acetaminophen on proliferation of ER+ or ER-cultured breast cancer cells. 


\section{EXPERIMENTAL MODELS}

\section{FOR STUDYING THE NORMAL AND CANCEROUS BREAST}

\subsection{In Vitro Models}

\subsubsection{Breast Cell Cultures Advantages and Disadvantages}

There are advantages offered by human cell culture, in vitro models relative to in vivo animal models (Adams, 1988). First, to understand normal and aberrant epithelial cell growth control in humans it is best to study human epithelial cells. While non-human and non-epithelial cell studies provide valuable information, there are many differences between these cell types and it is more likely that cells from humans provide more accurate models for human disease than nonhuman cells. Second, cells can be grown in monolayer and are always available for experiments at minimal cost. The unlimited growth of these cells allows one to perform numerous experiments with homogenous cell populations. Third, all cells are exposed to the same hormonal and nutritional conditions. Medium can be defined providing additional means for controlling the environment and eliminating unknown serum factors. Due to these advantages, cultured human breast cells offer good models especially for mechanistic studies of pharmacologic agent action and for studies of proliferation and other critical phenomena that govern breast cancer. A better understanding of these systems can lead to information that can be exploited to develop better strategies to pharmacologically control this disease. 
Such in vitro cell culture systems, however, have limitations. First, normal and aberrant cellular processes in vivo involve complex interactions within three dimensional organ systems. Thus, while cultured cells provide good models for homotypical cell interactions, they do not provide heterotypical cell interaction information (unless cocultures are used). Second, undetected viral or mycoplasmic contamination can alter growth rates and normal responses. Overall, many hypotheses are difficult to test under in vivo conditions because it is impossible to control all the variables involved. Eventually, hypotheses generated from in vitro experiments require verification in the intact organism and vice versa, detailed studies of mechanisms of action of various compounds requires in vitro controlled conditions. 


\subsubsection{Normal Breast Cells in Culture}

Widely used in vitro models for studying the dynamics governing normal mammary cells are the human mammary epithelial cells (HMEC). HMEC are derived from reduction mammoplasty tissues followed by post-selection from subpopulations of normal cells that display long-term growth. Post-selection cells grow rapidly (doubling times of 18-24 hrs). However, it is noteworthy that cells with long-term growth potential represent only a unique subpopulation of originally cultured cells. Only a small fraction $(\sim 3-10 \%)$ of normal epithelial cells in vivo show detectable estrogen receptor levels and this population is preferentially localized in non-basal layers. However, HMEC do not have estrogen and progesterone receptors (Stampfer and Bartley, 1987). Since medium that is fed to these cells includes insulin, glucocorticoid, EGF, isoproterenol or other cAMP stimulator, bovine pituitary extract and transferrin, it is possible that one or more of these factors negatively regulate ER/PR receptors and eventually an ER-/PRsubpopulation adapts to culture conditions. Estrogen-induced epithelial proliferation does not occur in response to estrogen unless cells are cocultured with stromal cells (Stampfer and Bartley, 1987). It is believed that an interaction between various growth factors and estrogen are responsible for normal mammary epithelial growth and while evidence from ER in epithelium exists, it is not yet clear that growth responses of normal cells result from direct effects of estradiol (Stampfer and Bartley, 1987). 


\subsubsection{Breast Cancer Cells in Culture}

There are various breast cancer cell lines that can be used in cell culture research. Among other characteristics, the retention of ER's and PR's by some breast cancer cells is one feature of which this research is taking advantage. Cells used in this research include MCF7, T47D, and ZR-75-1 cells that are ER+/PR+ and MDA-MB-231 and HS578T cells that are ER-/PR- (Shymala, 1985; Clarke 1995). All these cell lines were derived from pleural effusions from postmenopausal women with breast carcinomas and they all have epithelial-like morphology. Levels of ER's found in ER+/PR+ cells are similar to those found in breast cancer biopsies. For example, MCF7 cells contain 60-100 fmoles of cytosol ER/mg cytosol protein $(\mathrm{Kd}=0.06-2.5 \mathrm{nM}), \mathrm{ZR}-75-1,30$ fmoles/mg ( similar Kd) while freshly excised breast biopsies contain up to a few hundreds fmoles $\mathrm{ER} / \mathrm{mg}$ cytosol protein. Usually breast cancer cells that are ER+/PR+ express both wild type and mutated receptors (Castles et al., 1995). MCF-7 cells have lower levels of ER $\beta$ relative to ER $\alpha$; ZR-75-1 cells have only $\mathrm{ER} \alpha$; and T47D cells have approximately equal amounts of both alpha and beta (Register and Adams, 1998; Enmark et al., 1997). Receptor occupancy by agonists leads to initial downregulation of ER's and proliferation. The ER+/PR+ cells are stimulated maximally by $10^{-8}-10^{-9}$ M $17 \beta$-estradiol and inhibited by $>10^{-7}$ M $17 \beta$-estradiol (Kasid et al., 1985). Proliferative endpoints often

monitored include ${ }^{3} \mathrm{H}$-thymidine incorporation, \% cells in DNA synthesis phase of cell cycle and cell numbers (Kasid et al., 1985). On the other hand, estrogen-independent cells (e.g., MDA-MB-231) do not contain ER alpha's and do not exhibit estrogen-stimulation. 
However, these cells do contain some wild type and variant ER beta's (Vlasic et al., 1998).

The T47D human breast cancer cell line has sublines that are ER positive and estrogen responsive, ER positive and estrogen resistant, or ER negative (Horwitz 1990). T47D variants used in this study include T47D co, T47DYA, and YB breast cancer cells. The breast cancer cell line T47Dco (Leslie et al., 1992) is composed of multiple cell populations with low levels of both wild type and mutant estrogen receptor (Leslie et al., 1992). T47Dco cells have 90\% lower ER levels than MCF7 cells (Berkenstam et al., 1989; Castles et al., 1995) and high PR levels (Horwitz et al., 1986). The PR's are independent of estrogen induction, and the T47Dco cell line is estrogen- and antiestrogen-resistant (Horwitz and Friedenberg, 1985; Graham et al., 1990; Leslie et al., 1992). Two of the three mutant T47Dco ER's are truncated near the end of the DNA binding domain and exhibit low DNA binding and constitutive function; a third mutant has a large deletion spanning the hinge region and part of the hormone-binding domain (Leslie et al., 1992; Horwitz 1990). If expressed, these mutant ER's lack hormone-binding capacity (Horwitz 1990). Other groups found that T47Dco expressed ER variant transcripts with exons 5 and 7 deleted (Castles et al., 1995).

Sartorius et al, in 1994 developed other T47D variants to allow the study of each PR isoform independently. A stable PR- subline (T47D-Y) of PR+ T47D breast cancer cells was first selected then T47D-Y cells were stably transfected with expression vectors encoding PRA or PRB. Two cell sublines were selected that express either B-receptors (T47D-YB) or A-receptors 
(T47D-YA) at levels equal to those seen in natural T47D cells. The receptors are properly phosphorylated, and like endogenous receptors, they undergo ligand-dependent down-regulation. Only B:B or A:A homodimers are present in each cell line (A:B heterodimers are absent). With agonists, cAMP-dependent, transcriptional synergism of progesterone response elementregulated promoters is seen in these cells. By contrast, in the presence of the antiprogestins RU486 or ZK112993, inappropriate transactivation occurs in YB cells but not in YA cells antiprogestins like ZK98299, that block PR-DNA binding, do not activate transcription in these cells. In conclusion, all these breast cancer cell types are valuable models for studying effects related to ER's or PR's. 


\subsection{In Vivo Experimental Models}

\section{Nude Mice}

In order to better understand and characterize the proliferative effect of acetaminophen on breast cancer cells and to determine the relevance of the in vitro findings, in vivo studies must be carried out. Therefore, one of the goals of this research was to determine if the observed in vitro effect of acetaminophen occurs also in vivo, in nude mice. The availability of the nude athymic mouse provides one of the best systems for the study of tumors outside the body of the patient. This mouse, homozygous for the nu mutation, is the most widely used immunodeficient rodent model in cancer research. The nude mutation $(\mathrm{nu})$ is located on mouse chromosome 11 and homozygous mice are essentially athymic (Clarke, 1996). The lack of a fully functional thymus is mainly responsible for the low levels of T-lymphocytes. Additionally, the virgin B-cells are

present but B-cell maturation is defective. Despite the severe immunodeficiencies, the homozygous nu/nu mice are remarkably robust because of their remaining immunocompetence. A peculiarity of these mice is their increased levels of natural killer cells that exceed the levels present in the normal mouse of the same background (Clarke, 1996).

The ovariectomized mouse model used in our experiment is important because it provides an endocrinologic environment equivalent with that of postmenopausal women (Clarke, 1996). Estrogen supplementation is usually necessary for tumors to develop in these mice (Clarke, 1996). The main advantage for using this model is that, unlike in normal animals in which the 
immune system is intact and which usually rejects tumor implants, human breast tumors and cells lines derived from human tumors can produce neoplasms when injected into nude mice (Giovanella, 1974; Clarke 1996). These animals are necessary to logically extend in vitro findings to an in vivo level but using the same cell types as those used in vitro. 


\section{RESEARCH PROJECT OBJECTIVES}

There are two main types of research objectives and experiments that this dissertation addresses: in vitro and in vivo. They are listed below:

\section{In Vitro Studies}

1) Determine if acetaminophen induces proliferation of breast cells. Test:

a) Breast cancer cells (ER+/PR+; ER-/PR+; ER-/PR-; where ER refers to ERalpha)

b) Normal breast cells

2) Determine if ERs in ER+/PR+ cells play a role in acetaminophen-induced proliferation. Test if:

a) antiestrogens inhibit acetaminophen-induced proliferation,

b) acetaminophen binds to ERs in breast cancer cells.

3) Determine if the $p$-phenol moiety in acetaminophen plays a role in proliferation.

4) Determine if acetaminophen metabolism can be detected in breast cancer cell microsomes. 


\section{In Vivo Studies}

Determine if acetaminophen affects tumor growth in nude mice inoculated with $\mathrm{ER}+\mathrm{PR}+$ breast cancer cells.

The next section comprises a description of the methods used to accomplish this research project. Then the following section summarizes the results from the experiments conducted to accomplish the above objectives and the last section discusses the findings. The discussion section also includes some suggestions regarding possible implications for humans and some future experiments that may be done to continue this project. 


\section{CHAPTER II. MATERIALS AND METHODS}

\section{Materials}

The T47D, ZR-75-1, and HS578T cells were purchased from the American Type Tissue Collection. Dr. J. Strobl (Department of Pharmacology and Toxicology, West Virginia University) donated the MCF7 and MDA-MB-231 cells. Dr. Kathryn Horwitz (Department of Endocrinology, University of Colorado) donated T47D variant cells. Corning tissue culture flasks and dishes $(35 \times 10 \mathrm{~mm})$, Whatman GF/A microfiber filters, and disposable sterile pipettes were purchased from Fisher, Pittsburgh, PA. Dulbecco's Modified Eagle's Medium (DMEM) and Minimum Essential Medium Eagle (MEME) with or without phenol red (PRF), Fetal Bovine Serum (FBS) regular or heat inactivated, glutamine, geneticin, and gentamicin were purchased from BioWhittaker, Walkersville, MD. HMEC cell media (Mammary Epithelial Cell Growth Medium, MEGM) and additives were from Clonetics (San Diego, CA). $P-, \quad m-, \quad o-$ acetamidophenol, trypsin, propidium iodide, and other chemicals were purchased from Sigma Chemical Co., St. Louis, MO and were the highest quality available. [2, 4, 6, $\left.7-{ }^{3} \mathrm{H}\right]$ Estradiol $(88.0 \mathrm{Ci} / \mathrm{mmol})$ and $\left[\right.$ methyl $\left.-{ }^{3} \mathrm{H}\right]$ thymidine $(80.0 \mathrm{Ci} / \mathrm{mmol})$ were purchased from Amersham Life Sciences. Seven-week-old ovariectomized and non-ovariectomized female BALB/c nu/nu mice were purchased from Harlan Sprague Dawley, Madison, WI. Estrogen pellets were purchased from Innovative Research of America, Toledo, OH. Rat S9 and human microsomes were purchased from Gentest Corporation (Woburn, MA). 


\section{Methods}

\subsection{Cell Culture}

The ER+/PR+ breast cancer cells, MCF7, T47D, ZR-75-1, and ER-/PR- cells, MDA-MB231, and HS578T cells were cultured in DMEM supplemented with $10 \%$ FBS and $50 \mu \mathrm{g} / \mathrm{ml}$ gentamicin. The ER-/PR+ cells (T47Dco, T47DYA, T47DYB) were maintained in Minimum Essential Medium Eagle (MEME) supplemented with $5 \%$ heat inactivated FBS, 0.292 g/L gentamicin, $6 \mathrm{ng} / \mathrm{L}$ insulin, and $10 \mathrm{ml} / \mathrm{L}$ of $100 \mathrm{x}$ non-essential amino acids. T47DYA and T47DYB cell culture medium was added geneticin. HMEC cells were maintained in MEGM supplemented with bovine pituitary extract $(13 \mathrm{mg} / \mathrm{ml}, 2 \mathrm{ml})$, hydrocortisone $(0.5 \mathrm{mg} / \mathrm{ml}, 0.5 \mathrm{ml})$, epidermal growth factor $(10 \mu \mathrm{g} / \mathrm{ml} .0 .5 \mathrm{ml})$, and insulin $(5 \mathrm{mg} / \mathrm{ml}, 0.5 \mathrm{ml})$.

Prior to experiments, all breast cancer cells were placed for 2-4 days in Phenol Red Free (PRF)-DMEM supplemented with $2 \%$ estrogen-free FBS and gentamicin. The medium must be phenol red free because phenol red itself has estrogenic activity, namely it stimulates proliferation and acts on the ER (Berthois et al, 1986; Rajendran et al., 1987). Because we studied the estrogenic activity of acetaminophen, we wanted to avoid this confounding variable (phenol red in medium). T47Dco cells were placed in PRF-MEME supplemented with $2 \%$ estrogen-free heat inactivated FBS, insulin, and amino acids. T47DYA and YB were added geneticin. HMEC cells were placed in PRF-MEGM with the same additives as those for cell maintenance. HMEC receive bovine pituitary extract instead of FBS; the bovine pituitary extract was tested and found to contain negligible levels of estradiol $(<2 \mathrm{pg} / \mathrm{ml})$. The FBS was stripped of estrogen according to the charcoal-dextran procedure described by Dabre et al. (1983). Analysis of stripped serum revealed negligible levels 
( $<2 \mathrm{pg} / \mathrm{ml}$ FBS) of estradiol (Ongphiphadhanakul et al., 1998). As mentioned in the introduction, these levels reflect prepubertal plasma estradiol levels that are $\sim 5 \mathrm{pg} / \mathrm{ml}$; these levels are not high enough to induce breast development. 


\subsection{Experimental Design}

Initially, to investigate the effects of acetaminophen on breast cancer cell DNA synthesis, a modified E-screen assay was designed to contain built-in redundancy. Two dichotomous groups of breast cancer cells (ER+ and ER-) were included to assure consistency in terms of dichotomy of response (e. g., ER+ cells were expected to respond to xenoestrogens while ER- cells were not). Multiple cell lines within each group of ER+ and ER- cells assured consistency of response within each group (e.g., T47D, MCF7, and ZR-75-1 cells were expected to show similar responses). Initially, to determine what effects acetaminophen has on breast cancer cells, two different endpoints that reflect DNA synthesis, ${ }^{3} \mathrm{H}$-thymidine incorporation into DNA and \% cells in the S phase of the cell cycle, assured consistency with respect to DNA synthesis patterns. Later other endpoints were monitored such as cell number and ER binding. These are all described in detail below. All cultures were depleted of estrogens as described above, then medium was replaced daily. Medium contained no additions (negative control), 3nM 17 betaestradiol (positive control), or $0.03-1 \mathrm{mM}$ acetaminophen. The same negative and positive controls were used for all experiments. 


\subsection{Endpoints in Vitro}

\section{${ }^{3}$ H-Thymidine Incorporation}

${ }^{3} \mathrm{H}$-thymidine incorporation into newly synthesized DNA was measured as one means of assessing the proliferative effects of estradiol and acetaminophen on breast cancer cells. In each experiment, cultures were divided into treatment groups that included: (1) negative control (medium alone); (2) positive control (3 $\mathrm{nM}$ estradiol); (3) $3 \mathrm{nM}$ estradiol $+0.1 \mathrm{mM}$ acetaminophen; (4-7) $0.03 \mathrm{mM}, 0.1 \mathrm{mM}, 0.3 \mathrm{mM}$, and $1 \mathrm{mM}$ acetaminophen, respectively.

The acetaminophen concentrations reflect therapeutic $(0.03-0.1 \mathrm{mM})$ and toxic $(1 \mathrm{mM})$ plasma level counterparts in humans (Forrest et al., 1982; Jensen et al., 1996). The estradiol concentration corresponds to physiological plasma levels in pregnant women (Vohrerr, 1967; Berne and Levy, 1993). Two milliliters of cell suspension were plated into $35 \mathrm{~mm}$ culture dishes or 6-well plates. Plating densities (cells/ml) varied from $0.3 \times 10^{5}$ (estrogen-nonresponsive cells) to $1.5 \times 10^{5}$ (estrogen-responsive cells), because estrogen-nonresponsive cells proliferate faster than estrogen-responsive cells.

Cells received phenol red-free and estradiol-free medium for a few days. Then, for most experiments, each day medium was aspirated and fresh media without or with compounds (as indicated in figure legends in the results section) were added once daily for the next three consecutive days. The exception to this dosing regimen was one set of experiments that was done to determine if the effects of acetaminophen are still observed under a different dosing regimen. In this case, cells received medium without or with compounds once, then after 1 day, cells 
received a second treatment or cells received the first treatment; after 3 days cells received a second treatment and were analyzed. Together with administration of the last treatment, cells received $3.6 \mu \mathrm{Ci} / \mathrm{ml}{ }^{3} \mathrm{H}$-thymidine $(17 \mu \mathrm{Ci})$ for 4 hours. Cells were washed with Hanks' Balanced Salt Solution, and then $10 \%$ trichloroacetic acid (TCA) was added to precipitate DNA. TCA was removed and the precipitate was dissolved in $1 \mathrm{ml} 0.1 \mathrm{~N} \mathrm{NaOH}$, then reprecipitated with $1 \mathrm{ml} 20 \%$ TCA and subsequently filtered on to GF/A filters. The filters were rinsed with $0.1 \mathrm{~N} \mathrm{HCl}$, then $70 \%$ ethanol and dried. The ${ }^{3} \mathrm{H}-\mathrm{DNA}$ was quantitated in a scintillation counter (Beckman Instruments, LS500TOL model). Each treatment group was assayed in triplicate and each experiment was repeated at least three times. Results from single, representative experiments are presented as counts per minute $(\mathrm{cpm}){ }^{3} \mathrm{H}$-thymidine incorporated into DNA and reflect relative DNA synthesis rate of the seven treatment groups within each cell line. 


\section{Percent S Phase Cells}

Flow cytometry was used to independently confirm the results obtained from ${ }^{3} \mathrm{H}-$ thymidine incorporation experiments for 3 of the cell lines (ER+: MCF7, T47D; ER-: MDA-MB231) and for T47 D variants. In flow cytometry studies, cultures were set up as described above, except that the cells were plated into $75 \mathrm{~cm}^{2}$ flasks. Cells were initially placed in phenol red- and estradiol-free medium. Then each of the following three days, old medium was aspirated and fresh medium with or without compounds was added once daily. For these experiments, only $0.1 \mathrm{mM}$ that reflects therapeutic plasma levels in humans and $1 \mathrm{mM}$ acetaminophen that reflects toxic levels in humans were selected for further testing. At the end of these experiments, cells were collected for flow cytometry analysis while medium was collected for LDH analysis. Cells were washed with Hanks' Balanced Salt Solution, collected by trypsinization and suspended in 1 ml Solution A (2 g trisodium citrate, $2 \mathrm{ml} \mathrm{NP-40,} 1.044 \mathrm{~g}$ spermine tetrahydrochloride, $0.121 \mathrm{~g}$ Tris dissolved in 21 distilled water) containing $0.03 \mathrm{mg}$ trypsin $/ \mathrm{ml}$ for 10 minutes. Then, $0.75 \mathrm{ml}$ Solution A containing trypsin inhibitor $(0.03 \mathrm{mg} / \mathrm{ml})$ and RNase $(0.08 \mu \mathrm{g} / \mathrm{ml})$ was added for 10 minutes, followed by $0.75 \mathrm{ml}$ solution A containing propidium iodide $(0.4 \mathrm{mg} / \mathrm{ml})$ and spermine $(1.16 \mathrm{mg} / \mathrm{ml})$ for an additional 10 minutes. Samples were analyzed in the WVU Flow Cytometry Facility with a Fluorescence Activated Cell Analyzer (Becton Dickinson Immunocytometry Systems, San Jose, CA). Results represent the \% cells in the S phase of the cell cycle, determined using the Modfit LT 2.0 software (Verity Software House). 


\section{Cell Numbers}

Because DNA synthesis can proceed toward either apoptosis or proliferation (Wiger et al., 1997), cell numbers have been determined to establish if acetaminophen induces proliferation. Estrogen-depleted cells were exposed to acetaminophen and estradiol for longer time periods to assess effects on cell number (see figure legends). Cells were plated at densities indicated in figures, compounds were added and at indicated times cells were trypsinized and counted in a hemocytometer. Results are presented as numbers of viable (trypan blue excluded) cells/plate, and viability was $\geq 95 \%$. 


\section{Cytotoxicity}

The objective of these studies was to determine if acetaminophen has toxic effects on breast cancer cells. The culture medium from cells was tested for LDH release to assess general cytotoxicity using a Sigma Diagnostics kit (Cabaud and Wroblewski, 1958; Amdador et al., 1963), and samples were read on a Gilford Response II Spectrophotometer. 


\section{Whole Cell ER Binding Assays}

The objective of these studies was to determine if acetaminophen competes with estradiol for binding to ERs. These assays were conducted as described with minor modifications (Strobl et al., 1984). Briefly, MCF7 cells were placed in 6-well plates in estrogen-depleted medium, then media with ${ }^{3} \mathrm{H}$-estradiol $(0.1-5 \mathrm{nM})$ without or with $600 \mathrm{nM}$ excess unlabeled estradiol were added. Experiments were stopped after 45 minutes or 18 hours incubation periods. Two time periods were investigated because some compounds with low affinity for the estrogen receptors can bind to receptors but after longer incubations that allow to reach steady-state conditions (Nagel et al., 1998).

Cells were rapidly rinsed twice with $2 \mathrm{ml} \mathrm{PBS}$, then lysed with $500 \mu \mathrm{l} 0.2 \mathrm{~N} \mathrm{NaOH}$, neutralized with $250 \mu \mathrm{l} 2 \mathrm{~N} \mathrm{HCl}$ for 15 minutes at room temperature, and counted in $4 \mathrm{ml}$ Ecolite scintillation fluid. Kd was determined to be $\sim 0.1 \mathrm{nM}$ then subsequent experiments determined the ability of $0.1-10 \mathrm{nM}$ unlabeled estradiol and of $0.1 \mu \mathrm{M}-1 \mathrm{mM}$ acetaminophen to compete with $0.1 \mathrm{nM}{ }^{3} \mathrm{H}$-estradiol for binding to ER's. Total and nonspecific binding were determined experimentally, then nmoles of specific binding of labeled estradiol were calculated. 


\section{Metabolism Studies}

\section{Cell Growth, Treatment and Microsomal Preparation}

The objective of these studies was to determine if acetaminophen metabolism could be detected in microsomes from breast cancer cells. Two types of cells were used for these experiments: ER+/PR+ cells (MCF7) and ER-/PR- cells (MDA-MB-231). Cells were grown such that $50-60 \mathrm{~T} 75 \mathrm{~cm}^{2}$ flasks of $\sim 70 \%$ confluent cells would be available for each of the four treatments involved and for the subsequent preparation of microsomes. Cells were depleted of estradiol and phenol red for a day then the controls received medium; the TCDD group received $10 \mathrm{nM}$ TCDD; the beta-naphtoflavone (BNF) group received $40 \mu \mathrm{M}$ beta-naphtoflavone; and the acetaminophen group received $0.1 \mathrm{mM}$ acetaminophen for 1 day. The rationale for the treatment with TCDD and BNF inducers was to induce the cytochrome P450 enzymes, which are capable of metabolizing acetaminophen. The next day, microsomes were prepared according to the procedure described in Lipscomb et al., 1998. Briefly, cells were isolated and sonicated in icecold homogenization buffer then centrifuged at $9,000 \mathrm{~g}$ for 20 minutes. The supernatant was decanted and centrifuged again at 100,000g for 90 minutes. The resulting pellet was resuspended in a microsome wash solution and was recentrifuged at $100,000 \mathrm{~g}$ for 90 minutes. Then the microsomes were resuspended in a small volume of resuspension solution containing $0.1 \mathrm{M}$ potassium phosphate buffer ( $\mathrm{pH} \sim 7.2$ ), $100 \mathrm{mM}$ EDTA, and $20 \%$ glycerol. The microsomes were stored at $-80^{\circ} \mathrm{C}$ for a few days up to a few weeks. The MCF7 experiment was done once and the MDA-MB-231 experiment was done twice. 


\section{Protein Level Measurement}

Protein standards were prepared from bovine serum albumin in PBS from a $1 \mathrm{mg} / \mathrm{ml}$ stock. The microsome samples were diluted to $100 \mu$ total volume PBS. Bradford reagent (1 ml) was diluted 1:4 in water before use and $1 \mathrm{ml}$ of mixture was added to each tube. After 20 minutes A $_{595}$ was determined using a spectrophotometer. The amount of protein was subsequently calculated based on the standard curve.

\section{HPLC Method for Detection of Metabolism}

The procedure for detection of acetaminophen-cysteine metabolites by HPLC was as described in Zaher et al., 1998. Assayed contained $125 \mu \mathrm{l}$ of microsomes (or S9 fraction) incubated with $250 \mu \mathrm{l}$ of cofactor solution (20 mM glucose-6-phosphate, $15 \mathrm{mM} \mathrm{MgCl} 2, .83 \mathrm{mM}$ NADP, 4 IU glucose-6-phosphate dehydrogenase) and $250 \mu \mathrm{l}$ of $15 \mathrm{mM}$ cysteine. The Nacetamidoquinone intermediate was trapped and transformed to the cysteine metabolite of acetaminophen. Controls included non-induced human liver microsomes and rat liver S9 fraction induced with Arochlor. The protein concentrations were measured as described above. Assays were preincubated at $37^{\circ} \mathrm{C}$ for 10 minutes. Then, $250 \mu \mathrm{l} 15 \mathrm{mM}$ acetaminophen were added to initiate reactions to each incubation sample except for some controls that did not contain acetaminophen. Twenty minutes after adding acetaminophen, reactions were stopped by addition of $750 \mu \mathrm{l}$ of ice-cold methanol. Additional controls were treated first with methanol then with the rest of the mixture to determine if acetaminophen shows any nonspecific binding to other $\mathrm{SH}$ groups. Other controls included solutions blanks and S9 + cofactor; S9 + cysteine; S9 + acetaminophen; $\mathrm{S} 9+$ cysteine + cofactor, $\mathrm{S} 9+$ cofactor + acetaminophen, and $\mathrm{S} 9+$ cysteine + 
acetaminophen. After incubation, the samples were stored at $-20^{\circ} \mathrm{C}$ overnight. The next day, samples were centrifuged at $4^{\circ} \mathrm{C}$ and the supernatants were filtered using Millipore filters $(0.22$ $\mu \mathrm{m}) . \mathrm{NaOH}$ was added to each HPLC sample to give a final $\mathrm{pH}$ 9. Samples (injection volume $100 \mu \mathrm{l})$ were analyzed by HPLC using a C18 column and UV detector at $254 \mathrm{~nm}$. The mobile phase was run at $1 \mathrm{ml} / \mathrm{min}$ and contained $12.5 \%$ methanol, $1 \%$ acetic acid in deionized distilled water at final pH 2.9 (Zaher et al., 1998). Retention times for acetaminophen and acetaminophencysteine were 10.3 and 7.7 minutes, respectively. 


\subsection{Endpoints in Vivo}

\section{Tumor Growth}

The objective was to determine if acetaminophen stimulates proliferation of MCF7 cells in vivo. The effects of acetaminophen on onset and/or progression of MCF7 tumors in nude, ovariectomized mice were investigated. The rationale for ovariectomized mice was to mimic the set up in vitro situation as closely as possible. The number of mice used was 40, with 10 mice per treatment group, and the experiment was conducted for 44 days. The treatment groups were: 1 ) negative control (no additions); 2) positive control, estradiol (E) pellets (60-day release); 3) estradiol pellets 21-day release then acetaminophen (A) gavaged daily for the next 23 days (days $22-44)$; 4) acetaminophen gavage daily from day 1 to day 44 . Mice were gavaged with $150 \mathrm{mg} / \mathrm{kg}$ acetaminophen, a dose that does not induce hepatotoxicity in mice (Prescott, 1996).

Ovariectomized mice were acclimated for a week then randomized. The mice were kept in sterile cages and bedding. Mice were fed Purina mouse chow 5058 (St. Louis, MO) and allowed sterile water ad libitum. The temperature was maintained at $26-29^{\circ} \mathrm{C}$ and the animals were kept under a 12-hour light and 12-hour dark cycle. Animals were kept inside a laminar-flow air filtration system.

On Day 0, 1 day before cell inoculation, 1 estradiol pellet per mouse (60-day release $1.7 \mathrm{mg}$ estradiol/pellet) was implanted into each mouse within group 2 (positive control, E group). The implants occurred on the back of the neck of each animal. In addition, 1 estradiol pellet was implanted into each of the 10 mice (21-day release $0.5 \mathrm{mg}$ estradiol/pellet) within treatment group 3 
$(\mathrm{E}+\mathrm{A})$ group. On Day 1, MCF7 cells were trypsinized, and inoculated at $\sim 8 \times 10^{6}$ cells $/ 0.1 \mathrm{ml} / \mathrm{mouse}$. Inoculation was performed in the fat pad of the upper left mammary gland using a tuberculin syringe equipped with a \#27 needle. Cell viability was $96 \%$ as determined by trypan blue exclusion. Tumor growth was recorded twice a week using a caliper. The volume was calculated using the formula $V_{\text {tumor }}=1.33 \pi r_{\text {short }}^{2} r_{\text {long }}$ (Clarke, 1996).

\subsection{Statistics}

Data were analyzed using one and two way (time course studies) ANOVA and Student ttests. Data are expressed as endpoint means \pm standard error. If $\mathrm{p}<0.05$, differences among means were considered statistically significant. Sample sizes were as follows: ${ }^{3}$ H-thymidine incorporation experiments, $\mathrm{n}=3$, binding assays, $\mathrm{n}=3, \mathrm{LDH}, \mathrm{n}=3, \% \mathrm{~S}$ phase cells, $\mathrm{n}=1$ or 2 (see figure legends). 


\section{CHAPTER III. RESULTS}

\subsection{Acetaminophen Effects on Breast Cells in Culture}

Figure 3.1 shows that estradiol and selected xenoestrogens contain the phenol moiety that is believed to participate in the estrogenic activity of these compounds. Note that acetaminophen also contains the phenol moiety.<smiles>CC12CCC3c4ccc(O)cc4CCC3C1CCC2O</smiles>

$17 \beta$-estradiol<smiles>CC(C)(c1ccc(O)cc1)c1ccc(O)cc1</smiles>

p-bisphenol A<smiles>[R]c1ccc(O)cc1</smiles>
substituted $p$-phenol<smiles>CCC(=C(CC)c1ccc(O)cc1)c1ccc(O)cc1</smiles>

$E$-diethylstylbestrol

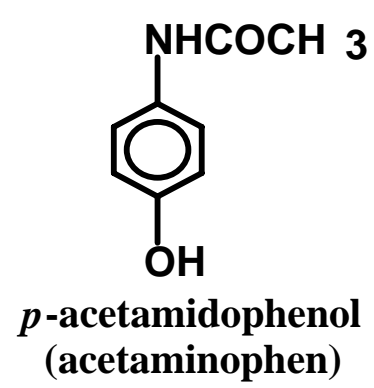<smiles>O=Cc1ccc(O)cc1</smiles>

Figure 3.1 Chemical structures of selected xenoestrogens and of acetaminophen. 


\subsection{1 ${ }^{3} \mathrm{H}$-Thymidine Incorporation}

The first set of studies was conducted to determine if acetaminophen mimics estradiol by stimulating proliferation in selected breast cells. Three proliferation endpoints were evaluated: (1) ${ }^{3} \mathrm{H}$-thymidine incorporation; \% S phase cells and (3) cell numbers. Results from experiments investigating ${ }^{3} \mathrm{H}$-thymidine incorporation are presented below.

Figures 3.2a, b, and c show the effects of acetaminophen on DNA synthesis in the $\mathrm{ER}+/ \mathrm{PR}+$ breast cancer cell lines MCF7, T47D, and ZR-75-1, respectively. As expected, relative to control, 3nM estradiol increases ${ }^{3} \mathrm{H}$-dT incorporation into the DNA of these cells. All of the $\mathrm{ER}+/ \mathrm{PR}+$ cells also respond to acetaminophen. Relative to control, $0.03 \mathrm{mM}$ acetaminophen induced a small but significant increase in DNA synthesis $(\mathrm{p}<0.05)$ in T47D (Figure 3.2b) and ZR-75-1 cells (Figure 3.2c) but this effect was not statistically significant (p>0.05) in MCF7 cells (Figure 3.2a).

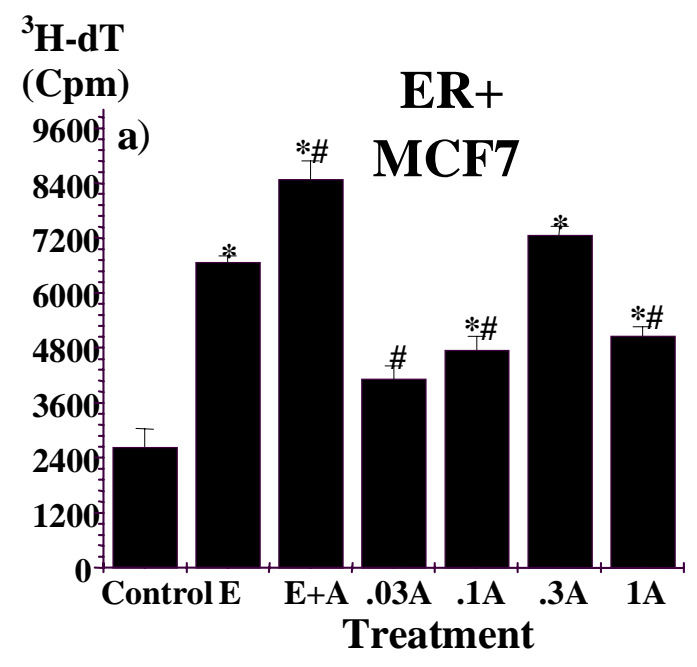




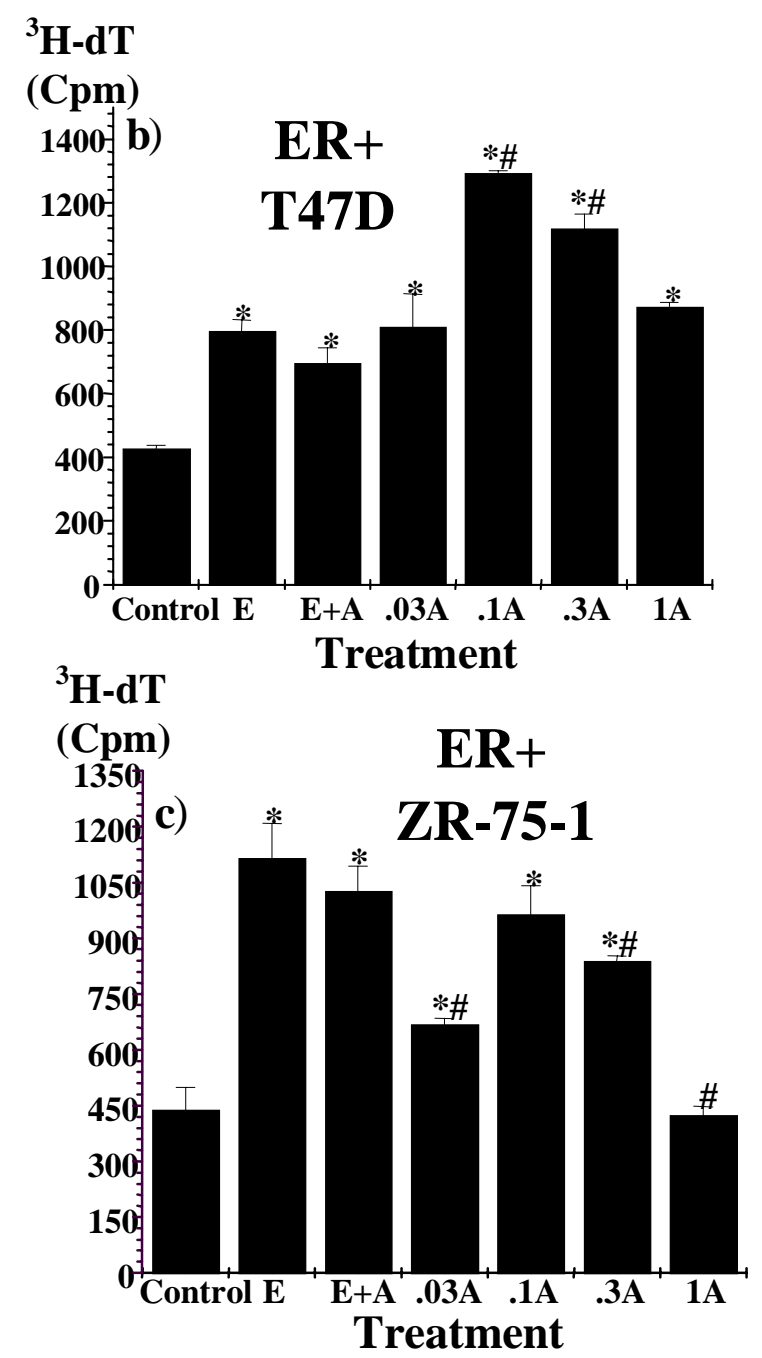

Figure 3.2 Effects of acetaminophen on ${ }^{3} \mathrm{H}$-thymidine incorporation into DNA in estradiolresponsive (ER+/PR+) human breast cancer cells: (a) MCF7, (b) T47D, and (c) ZR-75-1. Cells were placed in estrogen-free PRF-DMEM, then three consecutive doses ( 1 dose/day) of 3 $\mathrm{nM}$ estradiol (E), 0.03-1 $\mathrm{mM}$ acetaminophen (A), $3 \mathrm{nM}+0.3 \mathrm{mM} \mathrm{A}$ (MCF7), or $3 \mathrm{nM} \mathrm{E}+0.1$ mM A (T47D; ZR-75-1) were administered (see experimental design). Incorporation of ${ }^{3} \mathrm{H}-$ thymidine $\left({ }^{3} \mathrm{H}-\mathrm{dT}\right)$ into DNA was determined 4 hours after the last addition and is reported as mean ${ }^{3} \mathrm{H}$-dT incorporated into DNA (expressed in counts per minute, cpm; $n=3$ ) + /- standard 
error of the mean. Symbols * and \# indicate statistically significant differences in means $(\mathrm{p}<$ 0.05 ) relative to control and estradiol treatments, respectively.

Figure 3.2 shows that $0.1 \mathrm{mM}$ (T47D and ZR-75-1) and 0.3mM (MCF7) acetaminophen induced maximal increases in ${ }^{3} \mathrm{H}-\mathrm{dT}$ incorporation $(\mathrm{p}<0.05)$ while $1 \mathrm{mM}$ acetaminophen induced a smaller increase in ${ }^{3} \mathrm{H}-\mathrm{dT}$ incorporation. For MCF7 and T47D cells, the relative DNA synthesis induced by $1 \mathrm{mM}$ acetaminophen is small but significantly different from control $(\mathrm{p}<0.05)$, while for ZR-75-1 this effect is not significantly different from control ( $p>0.05)$. The relative magnitude of DNA synthesis induced by $0.1 \mathrm{mM}$ acetaminophen (T47D and ZR-75-1) and 0.3 $\mathrm{mM}$ acetaminophen (MCF7) is approximately equal to that induced by $3 \mathrm{nM}$ estradiol. Acetaminophen reproducibly stimulated DNA synthesis in all the ER+ cells tested. However, in different experiments, the relative magnitudes of acetaminophen- and estradiol-induced DNA synthesis varied somewhat (Figures $3.2 \mathrm{a}$, b). In T47D and ZR-75-1 cells, the $3 \mathrm{nM}$ estradiol + $0.1 \mathrm{mM}$ acetaminophen mixture induced an increase in DNA synthesis comparable in magnitude to that of $3 \mathrm{nM}$ estradiol alone ( $\mathrm{p}>0.05)$. In MCF7 cells, the mixture induced a DNA synthesis rate that is slightly greater than either estradiol alone or acetaminophen alone.

Figures 3.3a and 3.3b show the effects of estradiol and acetaminophen on the estrogennonresponsive breast cancer cells, MDA-MB-231 and HS578T, respectively. In these cells, neither estradiol nor acetaminophen increased DNA synthesis ( $p>0.05)$. For MDA-MB-231cells (Figure 3.3a), 1mM acetaminophen significantly reduced DNA synthesis. 

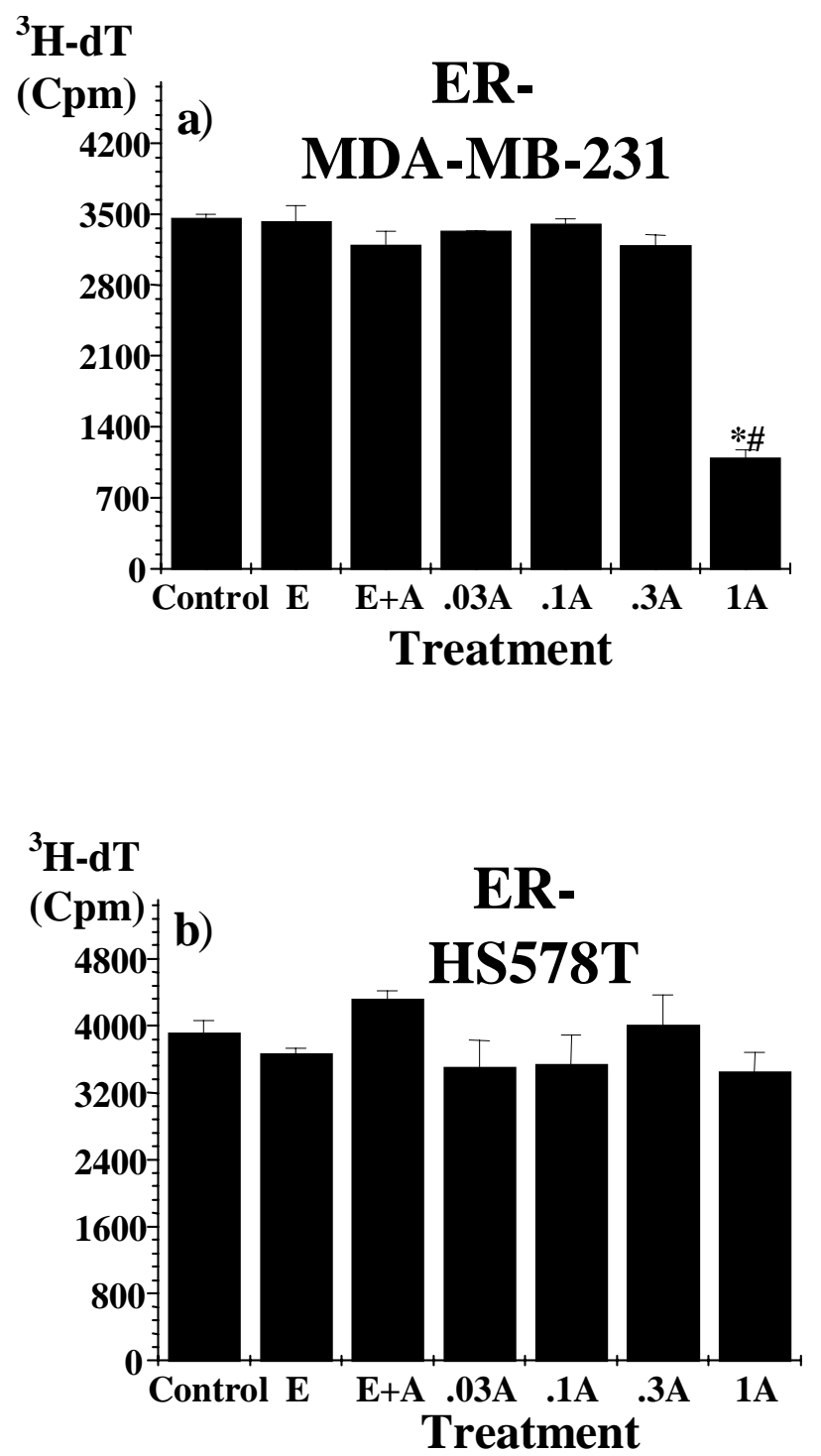

Figure 3.3 Effects of acetaminophen on DNA synthesis in estradiol-nonresponsive (ER- / PR-) human breast cancer cells: (a) MDA-MB-231 and (b) HS578T. Treatments and data collection occurred as described in Figure 2. Symbols * and \# indicate statistically significant differences in means, $n=3(p<0.05)$ relative to control and estradiol treatments, respectively. 
When the normal human mammary epithelial cells, HMEC, were tested in a similar manner with the breast cancer cells, neither acetaminophen nor estradiol induced any stimulatory effects (except that estradiol appeared slightly inhibitory after 3 additions).

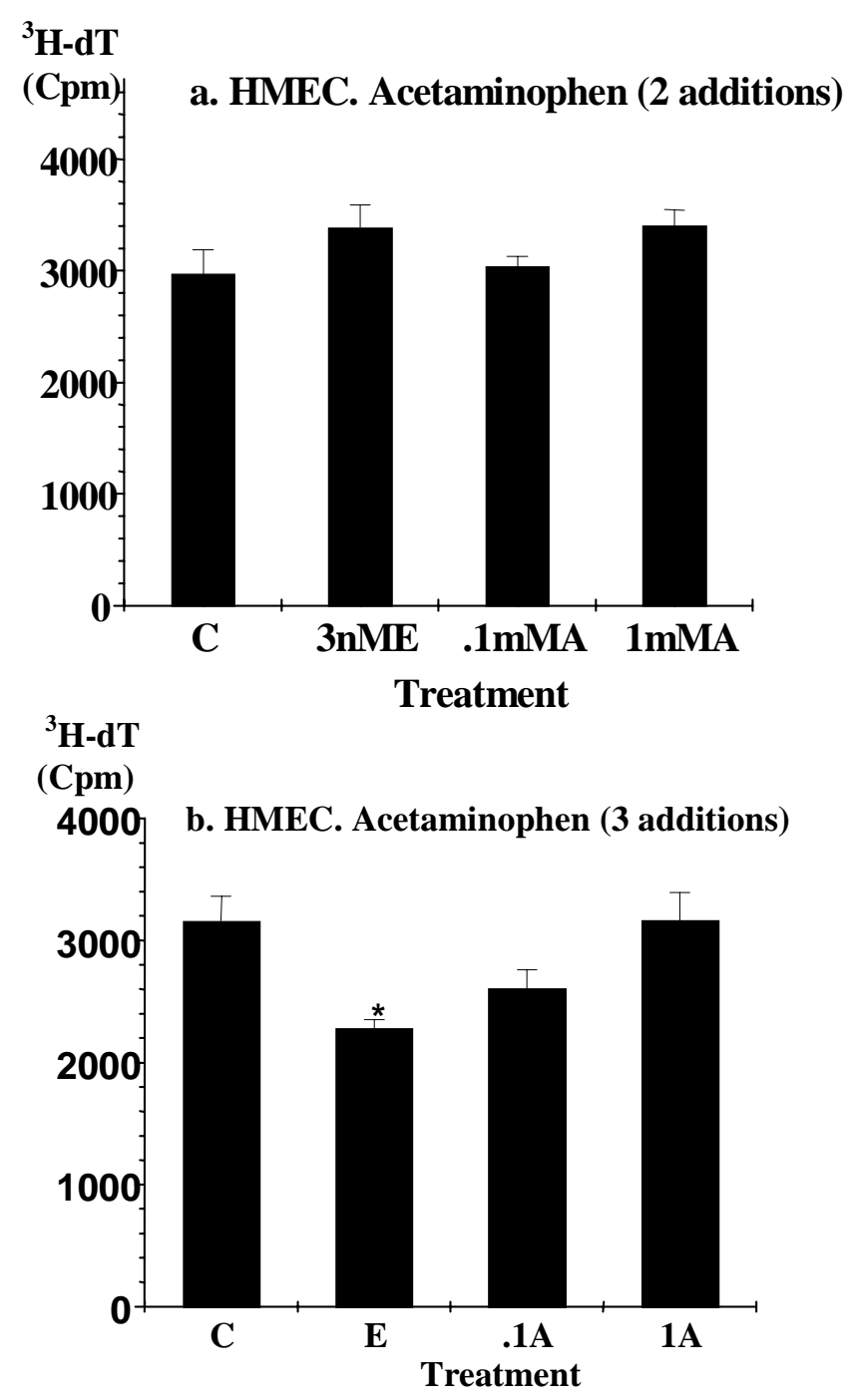

Figure 3.4 Effects of acetaminophen on DNA synthesis in normal breast, ER-/PR- HMEC cells. Treatments and data collection occurred as described in Figure 2 except data were collected after 2 (a) and after 3 (b) additions of treatments to cells $(n=3)$. 


\subsubsection{Percent S Phase Cells}

Figures 3.5a, b, and c present the effects of acetaminophen and of estradiol on \% MCF7, T47D, and MDA-MB-231 cells in S phase, respectively. In these studies, flow cytometry was used to determine $\%$ cells in the S phase of the cell cycle. In both MCF7 and T47D cells, $0.1 \mathrm{mM}$ acetaminophen alone and $3 \mathrm{nM}$ estradiol alone induced an approximately 2 fold increase in the $\% \mathrm{~S}$ phase cells relative to control cells (Figures $3.5 \mathrm{a}$ and $3.5 \mathrm{~b}$ ). The combination of acetaminophen and estradiol also induced an approximately 2 -fold increase in $\% \mathrm{~S}$ phase cells. In all the ER+ cells tested, both the $\% \mathrm{~S}$ phase cells (Figures $3.5 \mathrm{a}$ and $3.5 \mathrm{~b}$ ) and the ${ }^{3} \mathrm{H}-\mathrm{dT}$ incorporation into DNA (Figures 3.2a and 3.2c) were increased by acetaminophen and by estradiol. Figure $4 \mathrm{c}$ shows that neither estradiol nor acetaminophen increased $\% \mathrm{~S}$ phase cells of ER-, MDA-MB-231 cells (assessed by flow cytometry), also consistent with ${ }^{3} \mathrm{H}$-dT incorporation data (Figure 3.3a).

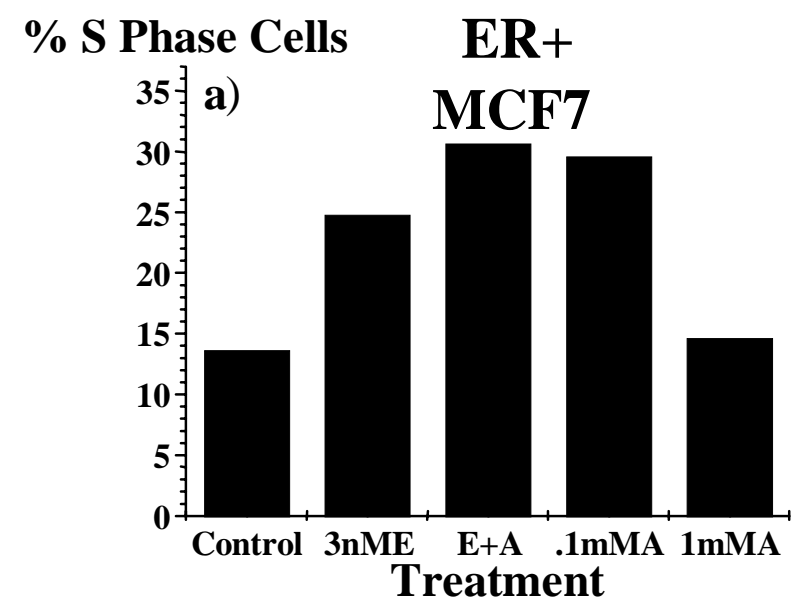



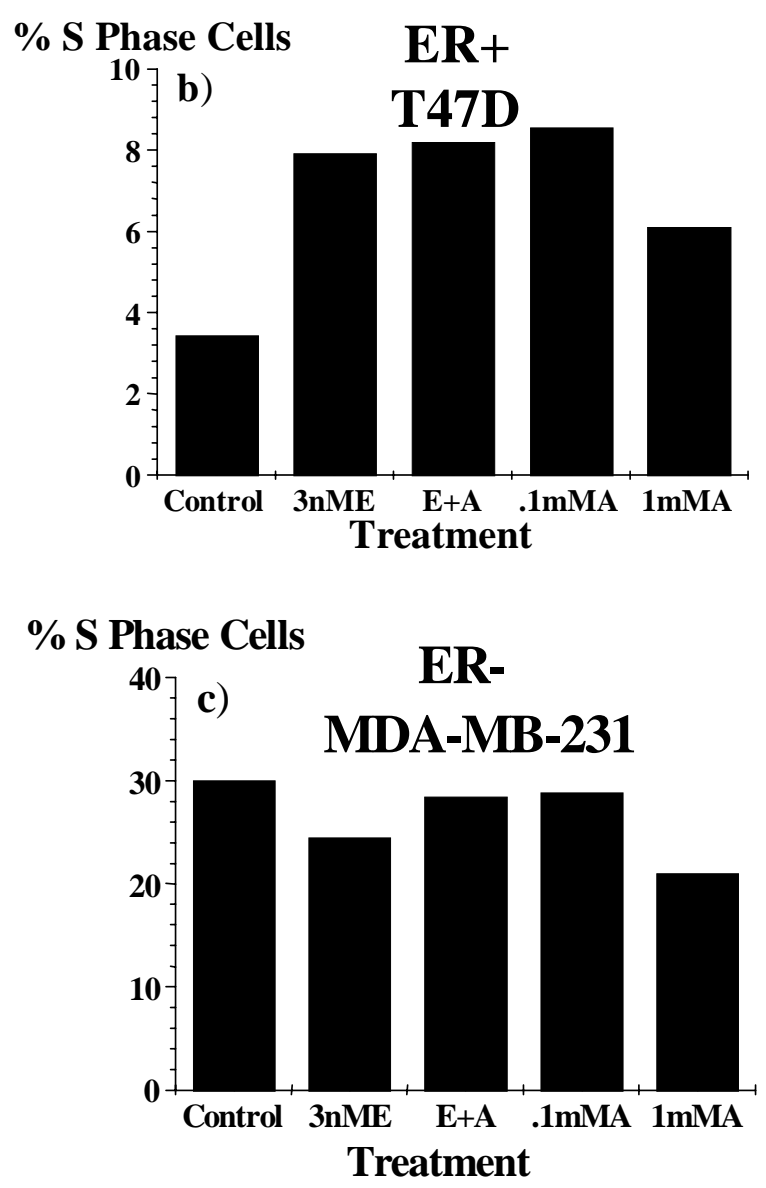

Figure 3.5 Effects of acetaminophen on \% $\mathrm{S}$ phase cells in estradiol-responsive (ER+) human breast cancer cells, (a) MCF7 and (b) T47D, and estradiol-nonresponsive (ER-) breast cancer cells, (c) MDA-MB-231. Cells were plated in estrogen-free, PRF-DMEM, then three consecutive doses (1 dose/day) of $3 \mathrm{nM}$ estradiol (E), $0.1 \mathrm{mM}, 1 \mathrm{mM}$ acetaminophen (A), 3 $\mathrm{nM} \mathrm{E}+0.3 \mathrm{mM}$ A (MCF7) or $3 \mathrm{nM} \mathrm{E}+0.1 \mathrm{mM}$ A (T47D; MDA-MB-231) were administered (see experimental design). Cells were collected and analyzed 4 hours after the last addition. Results are presented as \% $\mathrm{S}$ phase cells. The sample size in the experiments shown was $\mathrm{n}=1$, experiments were repeated were found reproducible and representative results are shown. 


\subsubsection{Cell Numbers}

To verify that the indirect proliferative endpoints tested reflect increases in cell numbers, $\mathrm{ER}+/ \mathrm{PR}+$ breast cancer cells were counted after being cultured in the presence and absence of acetaminophen and estradiol. Results are shown below for one of the cell lines tested (Figure 3.6) and they are consistent with previous data. Figure 3.6 shows the effects of acetaminophen and estradiol on T47D cell proliferation as a function of time. Two days after first addition of drugs (day 3$)$, only $3 \mathrm{nM}$ estradiol $+0.1 \mathrm{mM}$ acetaminophen induced a significant increase $(\sim 1.5$ fold) in cell number above control. Subsequently, both estradiol and acetaminophen induced statistically significant increases in cell proliferation above control. By day 9, $0.1 \mathrm{mM} p$ acetamidophenol (acetaminophen), estradiol, and estradiol + acetaminophen induced 1.8, 3.1, and 4.0 fold increases in cell proliferation above control, respectively. Physiologic concentrations of estradiol are typical positive controls in tests evaluating estrogenicity of chemicals, and the proliferation induced by estradiol in this study is consistent with previous studies (Kasid et al., 1985). 


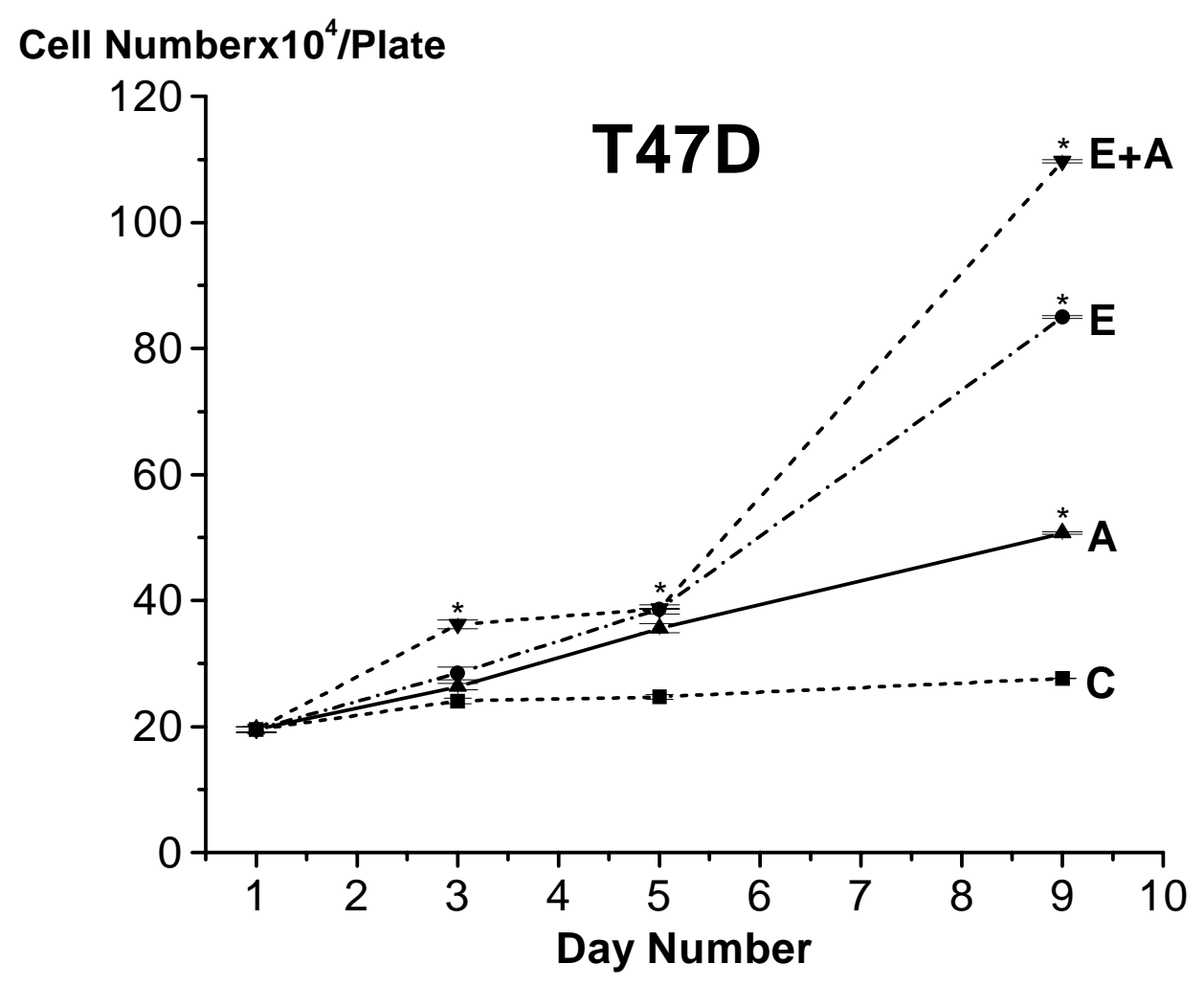

Figure 3.6 Effects of $0.1 \mathrm{mM}$ acetaminophen on T47D cell proliferation. Cells were seeded into 35x10 mm plates in estrogen-depleted medium for 2 days. Fresh estrogen-free medium was then added at days 1, 3, and 6 with indicated compounds: $0.1 \mathrm{mM}$ acetaminophen (A), 3nM estradiol (E) or $0.1 \mathrm{mM}$ acetaminophen $+3 \mathrm{nM}$ estradiol $(\mathrm{E}+\mathrm{A})$; controls $(\mathrm{C})$ contained vehicle only. Cell numbers were determined by hemocytometer counts at days 3, 5 and 9; “*” indicates statistically significant differences from control. 


\subsubsection{Acetaminophen Induces ${ }^{3} \mathbf{H}$-Thymidine Incorporation under Other Dosing Regimens}

Another objective of this study was to determine if acetaminophen stimulates proliferation responses under different, simpler dosing regimens. Previously, we established that $0.1 \mathrm{mM}$ acetaminophen induces ${ }^{3} \mathrm{H}$-dT incorporation into DNA if added to cells once daily for three days. The results shown in Figure 3.7 below are from studies done by adding acetaminophen to cells once for one day (a) and once for three days (b, c) to MCF7 cells (a, b) and T47D cells (c). Acetaminophen does not stimulate ${ }^{3} \mathrm{H}-\mathrm{dT}$ incorporation into DNA of MCF7 cells after 1 day (a) although estradiol does induce ${ }^{3} \mathrm{H}-\mathrm{dT}$ incorporation in this period. However, 1 acetaminophen or estradiol treatment is sufficient to induce this response after 3 days $(b, c)$ in both MCF7 and T47D cells.

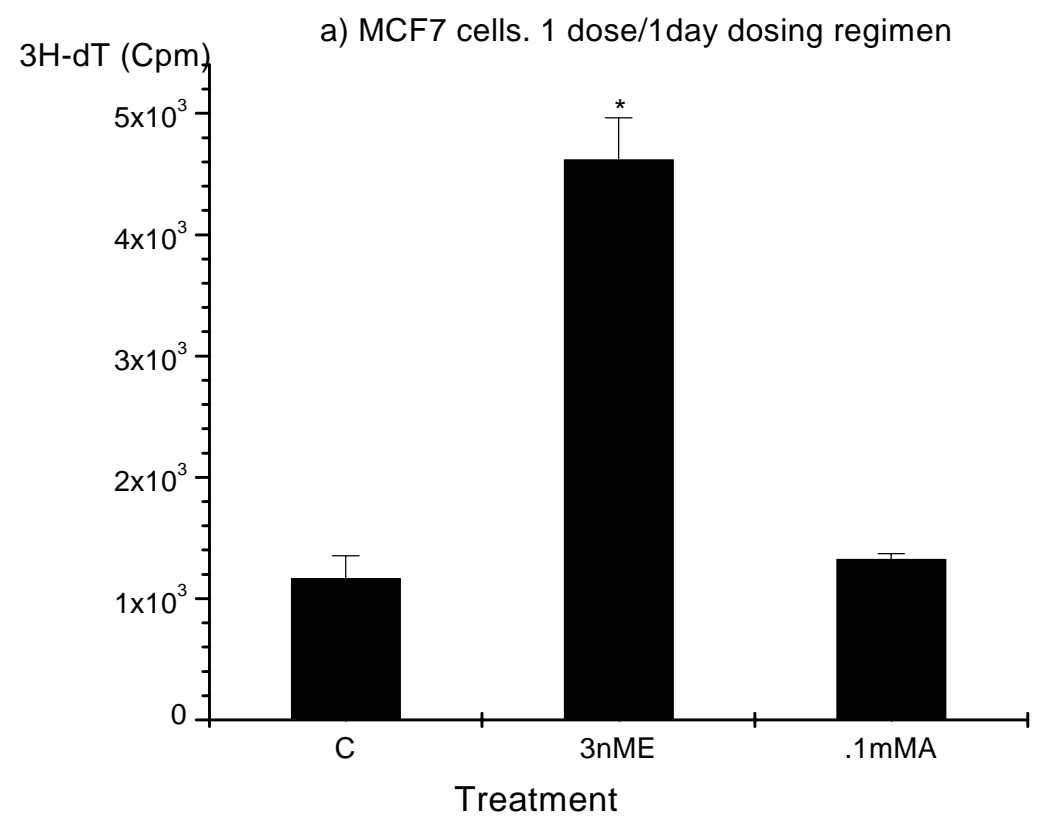



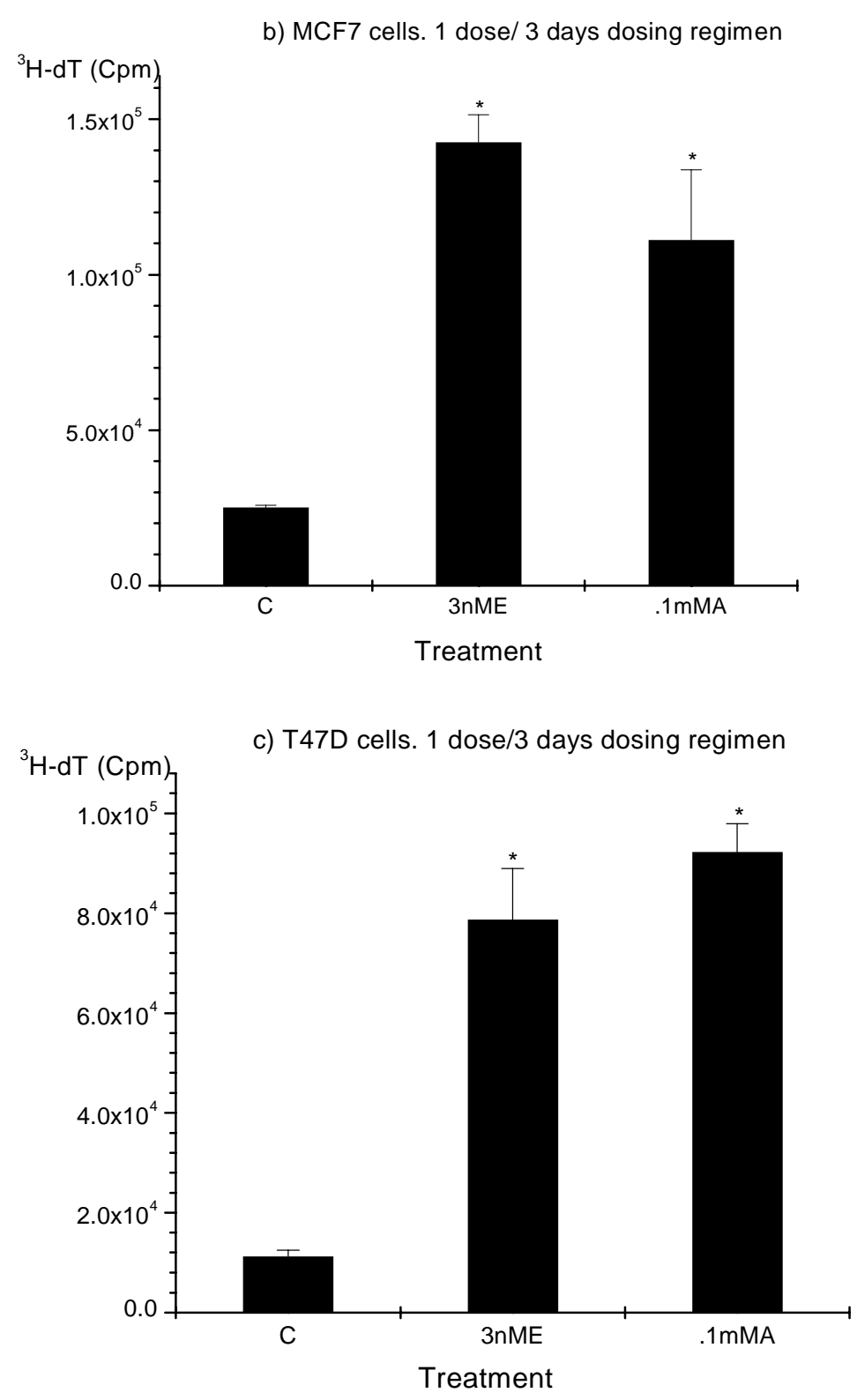

Figure 3.7 Acetaminophen stimulates ${ }^{3} \mathrm{H}-\mathrm{dT}$ incorporation into DNA under a 1 dose/3days dosing regimen in MCF7 cells (b) and T47D cells (c) but not under a 1 dose/1 day regimen in MCF7 cells (a). Cells were depleted of phenol red and estradiol 2-4 days, then cells were fed once fresh medium (C), or medium with $3 \mathrm{nM}$ estradiol (3nME) or $0.1 \mathrm{mM}$ acetaminophen $(0.1$ mM A). Cells were exposed to ${ }^{3} \mathrm{H}-\mathrm{dT}$ in the last 4 hours of culture, then analyzed by scintillation counting after 1 day (a) or 3 days (b, c), as described in the methods section. 


\subsection{Cytotoxicity}

Medium from cultures used for flow cytometry was assayed for LDH activity. None of the treatments cause significant loss of cellular LDH into medium (data not shown). This suggests that the effects induced by acetaminophen are not cytotoxic and the fact that $1 \mathrm{mM}$ acetaminophen does not induce proliferation in ER+ cells does not appear to be due to cytotoxicity.

\subsection{Mechanism of Acetaminophen-Induced Proliferation}

\subsubsection{T47D Variants Studies}

Once it was established that acetaminophen stimulates proliferation of $\mathrm{ER}+/ \mathrm{PR}+$ breast cancer cells, we investigated how may acetaminophen induce this effect. It was apparent that there is a correlation between acetaminophen effects and the presence or absence of ER/PR; that is, like with estradiol, only cells that are $\mathrm{ER}+\mathrm{PR}+$ undergo acetaminophen-induced proliferation. In order to understand the involvement of ER's in acetaminophen-induced proliferation, T47D variants were tested. These variants, as explained in introduction and methods have low to negligible ER but high PR levels. The rationale for testing these cells was to determine if acetaminophen stimulates proliferation of these cells in order to differentiate between effects mediated by ER and PR. Acetaminophen could elicit effects like estrogen due to its phenol moiety. If acetaminophen acted like estradiol, these ER deficient cells were expected not to proliferate. On the other hand, acetaminophen also contains an acetyl group, like some progestins. Thus, if acetaminophen, acted like some synthetic progestins such as alphaketogestrel, these cells were expected to proliferate and if it acted like progesterone, these cells should be inhibited. Second, unlike the cells used in previous experiments, the three T47D 
variants (T47Dco, T47DYA and T47DYB) allow some level of discrimination between effects mediated by ER and by PR. For example, T47Dco have low ER, high PR AB heterodimers, A homodimers and B homodimers, while T47DYA have PRA homodimers only and T47DYB have PRB homodimers only.

Results presented in Figure 3.8 show that acetaminophen does not induce proliferation in either T47Dco or T47DYA or T47DYB cells (Figures 3.8a, b, c, d). On the contrary, at high concentrations $\sim 1 \mathrm{mM}$, like in MDA-MB-231 cells, acetaminophen inhibits proliferation. Such data are consistent with previous data and further support the hypothesis that acetaminopheninduced proliferation most likely depends on high ER levels but not PR (AB, A, B) and that acetaminophen mimics some estradiol effects (e.g., proliferation or lack of proliferation in specific cell types).

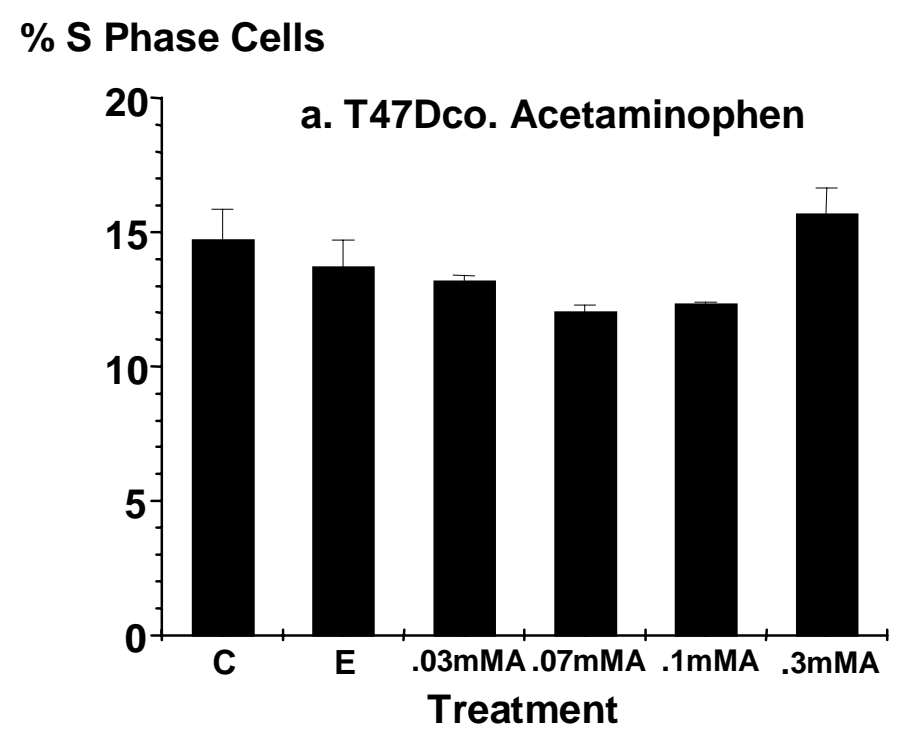




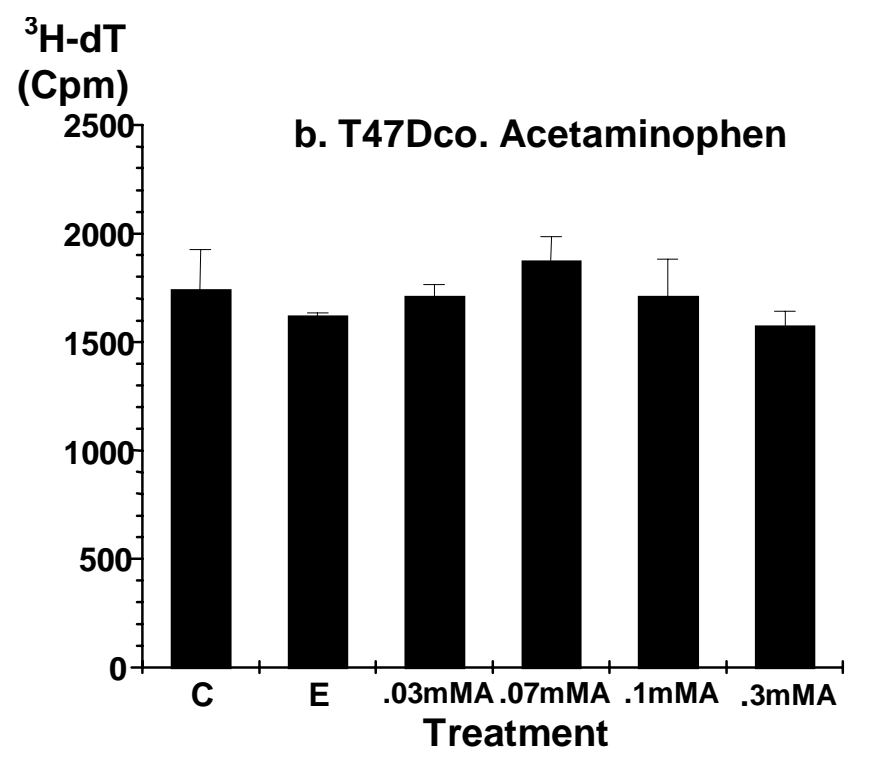

\% S Phase Cells

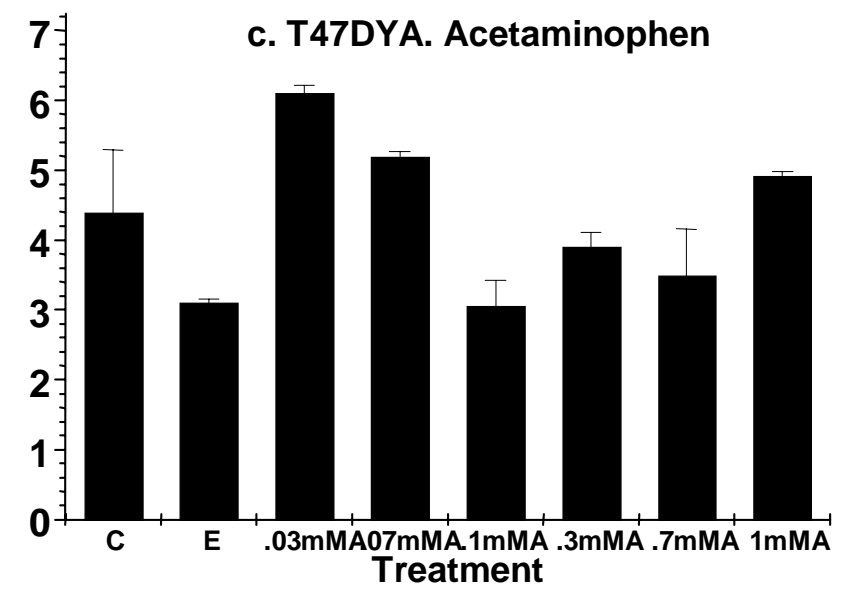

\% S phase cells

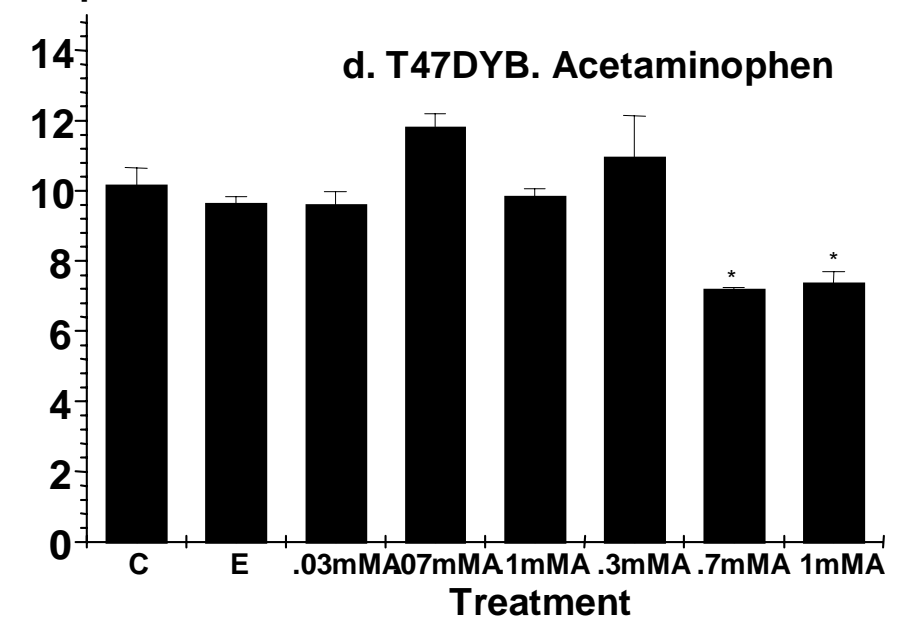


Figure 3.8 Effects of acetaminophen on T47Dco (a, b), T47DYA (c), and T47DYB (d) cells. (a, c, d) Cells were plated into $\mathrm{T} 75 \mathrm{~cm}^{2}$ duplicate flasks in estrogen-depleted medium for 2-4 days, then medium without additional compounds (control) or with compounds was replaced daily for 3 days. Cells were then analyzed by flow cytometry (see methods). Abbreviations: $\mathrm{C}=$ control (medium only); $\mathrm{E}=3 \mathrm{nM}$ estradiol; $0.03-1 \mathrm{mM} \mathrm{A}=0.03-1 \mathrm{mM}$ acetaminophen. (b) Cells were plated in triplicate into 6 well plates as in (a), and ${ }^{3} \mathrm{H}$-thymidine incorporation into DNA was determined as previously described; abbreviations are the same as (a). 


\subsubsection{Antiestrogen Studies}

To obtain further information about the involvement of ER in acetaminophen-induced proliferation, experiments were performed to determine if acetaminophen-induced proliferation could be inhibited by two antiestrogens, a partial antiestrogen (4-hydroxytamoxifen) and a complete antiestrogen (ICI182,780). The rationale was that if acetaminophen-induced proliferation involves ER, as data so far indicate, then antiestrogens should inhibit this effect. The following figures show effects of two antiestrogens on acetaminophen-induced proliferation of MCF7 and T47D cells, as reflected in \% cells in S phase of the cell cycle and cell number, respectively. Effects of antiestrogens on acetaminophen-stimulated incorporation of ${ }^{3} \mathrm{H}-$ thymidine into DNA were also assessed and found consistent with these results (data not shown). In MCF7 cells, ICI 182,780 inhibits acetaminophen- (Figure 3.9a) and estradiol-induced increases in \% S phase cells (Figure 3.9b).

a. MCF7. Acetaminophen-ICI 182,780

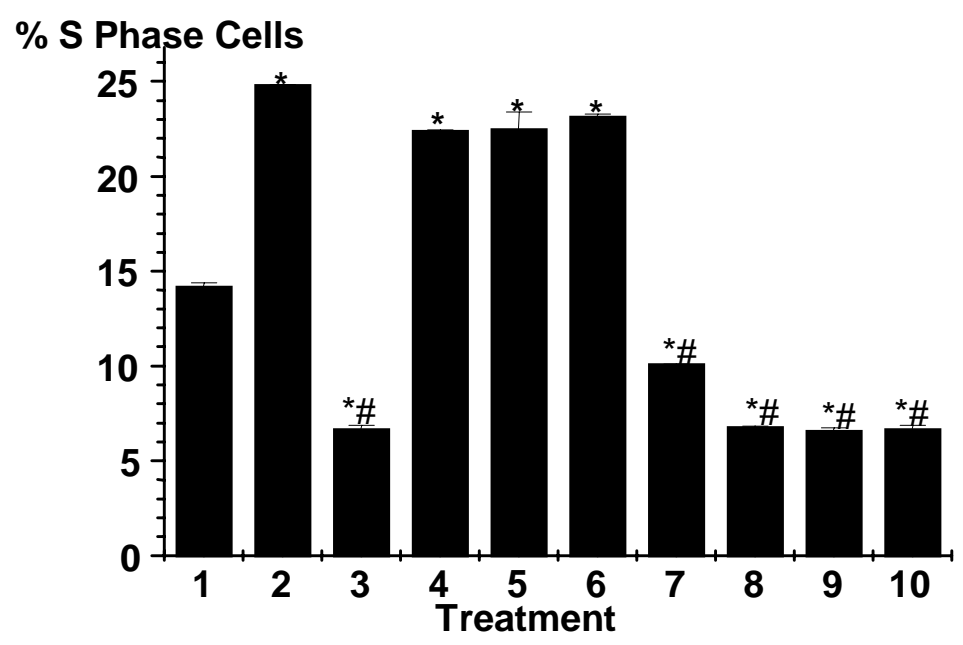




\section{b. MCF7. Estradiol-ICl182,780}

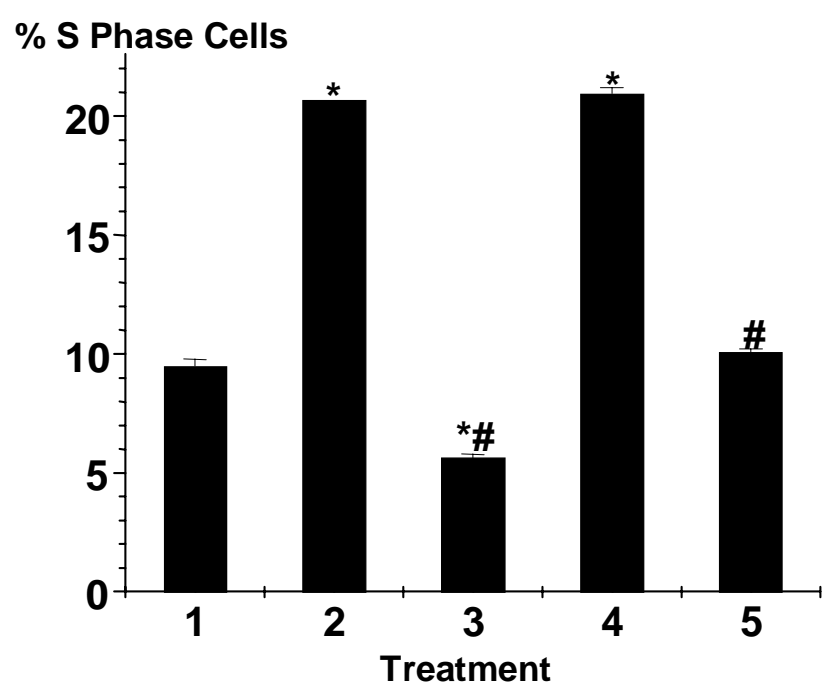

Figure 3.9 Effects of ICI 182,780 on (a) acetaminophen- and (b) estradiol-induced \% S phase MCF7 cells. Cells were plated in T75 $\mathrm{cm}^{2}$ flasks in estrogen-depleted medium for 2-4 days, then medium without additional compounds (control) or with compounds (treatments) was replaced daily for 3 days; cells were then analyzed by flow cytometry (see experimental section). Treatments in (a) are: (1) control; (2) $3 \mathrm{nM} 17 \beta$-estradiol; (3) $10^{-7} \mathrm{M}$ ICI 182,780; (4) $0.3 \mathrm{mM}$ acetaminophen; (5-10) $0.3 \mathrm{mM}$ acetaminophen + ICI 182,780 at $10^{-11} \mathrm{M}(5), 10^{-10} \mathrm{M}(6), 10^{-9} \mathrm{M}$ (7), $10^{-8} \mathrm{M}(8), 10^{-7} \mathrm{M}(9)$, and $10^{-6} \mathrm{M}(10)$, respectively. Treatments in (b) are: (1) control; (2) 3nM estradiol, (3) $10^{-7} \mathrm{M}$ ICI 182,780, (4-5) 3nM estradiol + ICI 182,780 at $10^{-9} \mathrm{M}$ (4) and $10^{-7}$ $M(5)$, respectively. Results depict \% S phase cells (n=2); “*” indicates statistically significant differences relative to control; and "\#” indicates statistically significant differences relative to estradiol. 
Figure 3.10 below shows that 4'-hydroxytamoxifen also inhibits both acetaminophenand estradiol-induced increases in \% MCF7 cells in S phase.

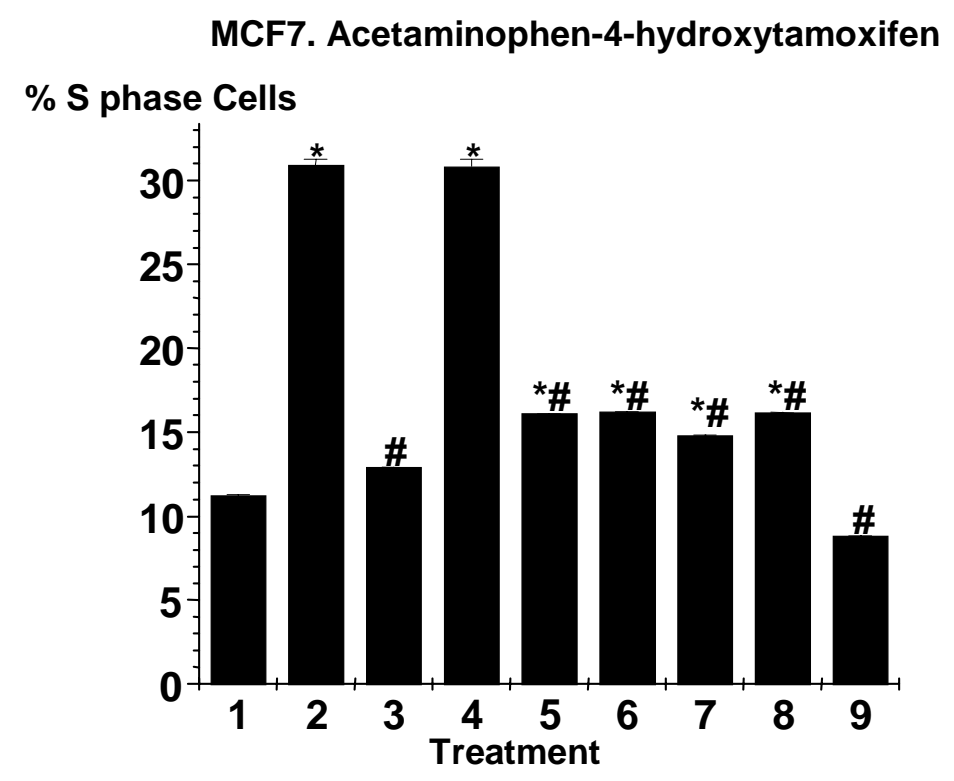

Figure 3.10 Effects of 4'-hydroxytamoxifen on acetaminophen- and estradiolinduced \% S phase MCF7 cells. Cells were treated as in Figure 3.9. Treatments are: (1) control; (2) 3 nM $17 \beta$-estradiol; (3) 10-6 M 4'-hydroxytamoxifen; (4) $0.3 \mathrm{mM}$ acetaminophen; (5-7) 0.3 $\mathrm{mM}$ acetaminophen $+4^{\prime}$-hydroxytamoxifen at $10^{-8} \mathrm{M}(5), 10^{-7} \mathrm{M}(6), 10^{-6} \mathrm{M}(7)$, respectively; (8-9) 3nM estradiol + 4' -hydroxytamoxifen at $10^{-7} \mathrm{M}(8)$, and $10^{-6} \mathrm{M}$ (9), respectively. Results depict \% S phase cells; “*” indicates statistically significant differences relative to control; and “\#” indicates statistically significant differences relative to estradiol. 
Figure 3.11 shows that, as expected, neither acetaminophen, estradiol nor ICI 182,780 have any effect on \% S phase cells in ER-/PR-, MDA-MB-231 cells.

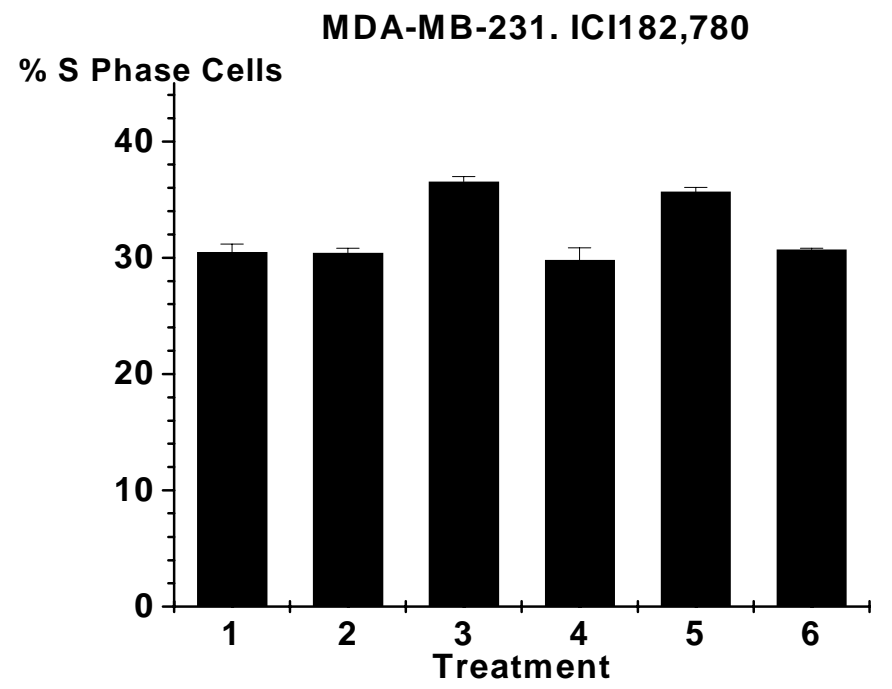

Figure 3.11 Effects of ICI 182,780 on \% S phase MDA-MB-231 cells. Cells were treated as in Figure 3.9. Treatments are: (1) control; (2) $3 \mathrm{nM} 17 \beta$-estradiol; (3) $10^{-7} \mathrm{M}$ ICI 182,780; (4) $0.1 \mathrm{mM}$ acetaminophen; (5) 3nM estradiol $+10^{-7} \mathrm{M}$ ICI 182,780, and (6) $0.1 \mathrm{mM}$ acetaminophen $+10^{-8}$ M ICI 182,780 (6). Results depict \% S phase cells. 
Figure 3.12a shows that ICI 182,780 inhibits both acetaminophen- and estradiol-induced increases in MCF7 cell number, consistent with studies demonstrating that $10^{-7} \mathrm{M}$ ICI 182,780 inhibits acetaminophen and estradiol stimulation of \% S phase cells. In addition, these data are consistent with other studies that demonstrate inhibition of estradiol-induced responses by ICI 182,780 at comparable concentrations (Noyes et al., 1996). Figure 3.12b shows that 4'hydroxytamoxifen $\left(10^{-6} \mathrm{M}\right)$ also inhibits acetaminophen- and estradiol-induced MCF7 cell proliferation. Similar results were obtained with T47D cells (Figure 3.13)

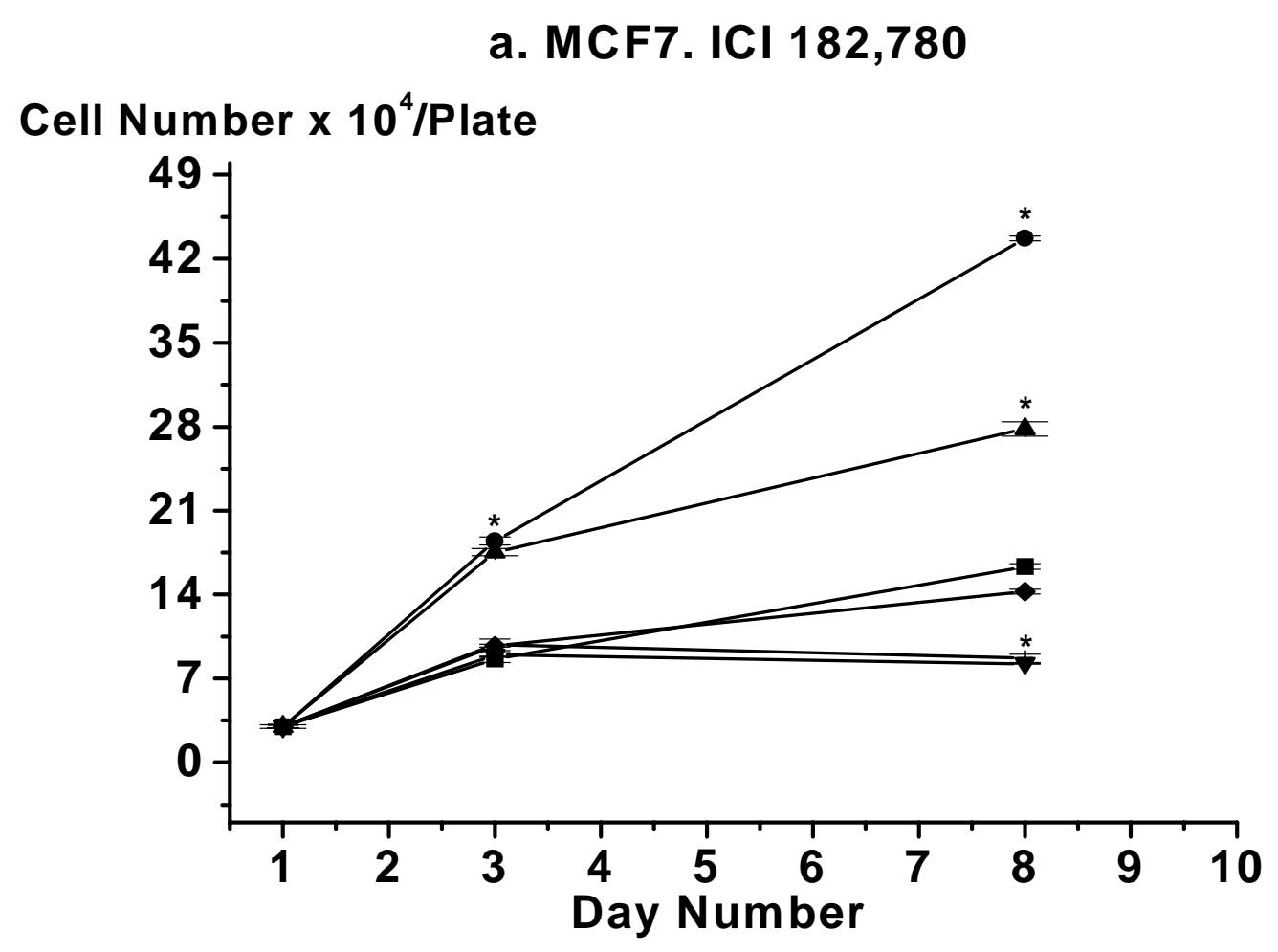




\section{b. MCF7. 4-Hydroxytamoxifen}

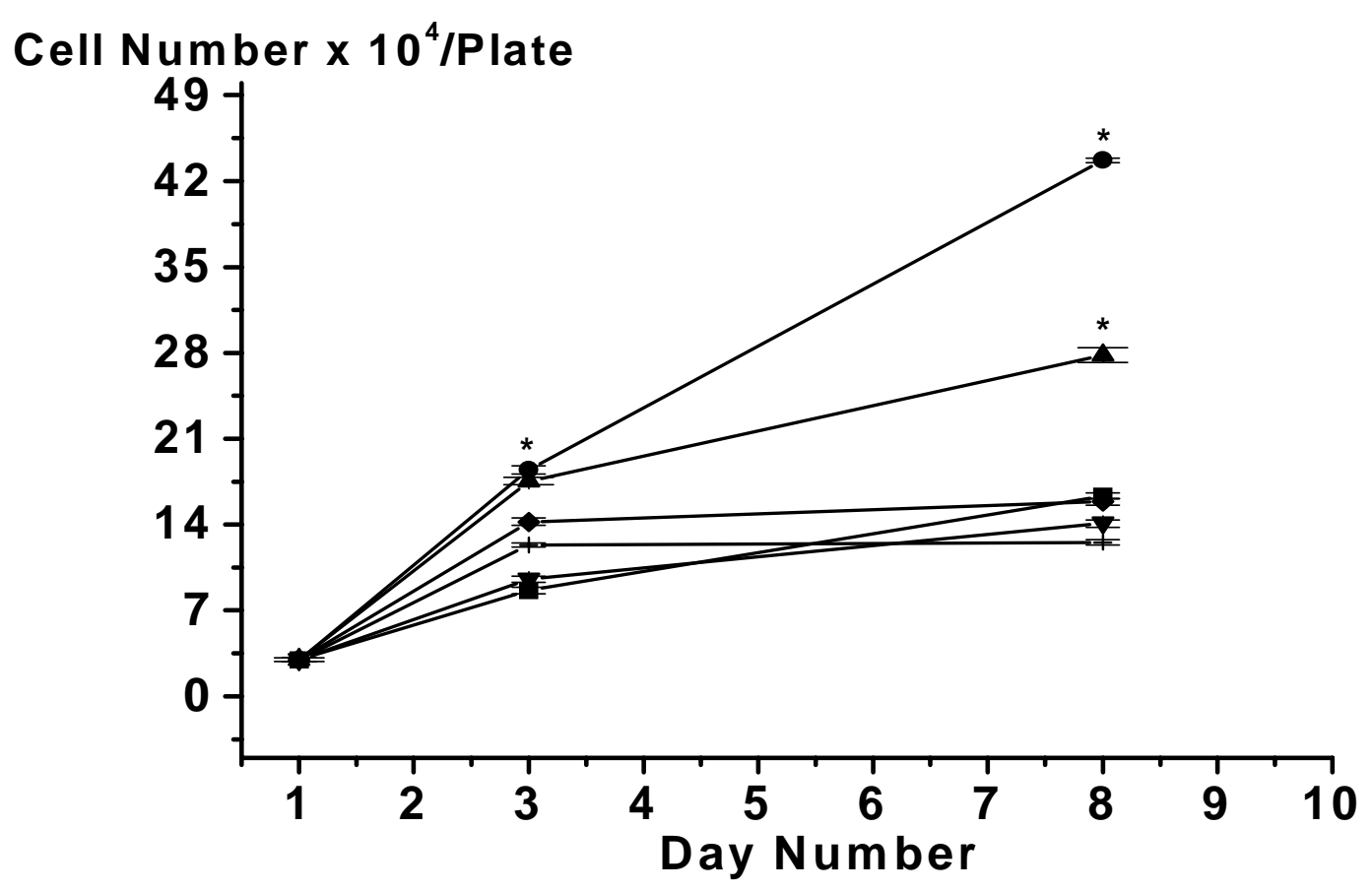

Figure 3.12 Effects of (a) ICI 182,780 and (b) 4'-hydroxytamoxifen on acetaminophen- and estradiol-induced MCF7 cell proliferation. Cells were plated in 35x10mm dishes, depleted of estradiol, and then medium with compounds were replaced twice over 7 days. Cell numbers were determined in presence of trypan blue from hemocytometer counts (see experimental section).

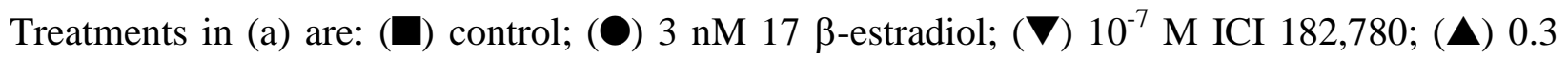
$\mathrm{mM}$ acetaminophen; $(\diamond) 0.3 \mathrm{mM}$ acetaminophen $+10^{-8} \mathrm{M}$ ICI 182,780; (|) $3 \mathrm{nM}$ estradiol $+10^{-7}$

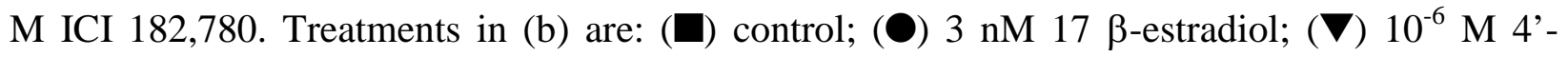
hydroxytamoxifen; (A) $0.3 \mathrm{mM}$ acetaminophen; $(\diamond) 0.3 \mathrm{mM}$ acetaminophen $+10^{-6} \mathrm{M} \mathrm{4}$ 'hydroxytamoxifen; (|) $3 \mathrm{nM}$ estradiol $+10^{-6} \mathrm{M}$ 4'-hydroxytamoxifen; “*” indicates statistically significant differences relative to control. 
Figure 3.13 demonstrates that, as in MCF7 cells, addition of either ICI 182,780 (Figure 3.13a) or 4'-hydroxytamoxifen (Figure 3.13b) to T47D cells inhibits both acetaminophen- and estradiol-induced proliferation.

\section{a. T47D. ICI 182,780 \\ Cell Number x $10^{4} /$ Plate}

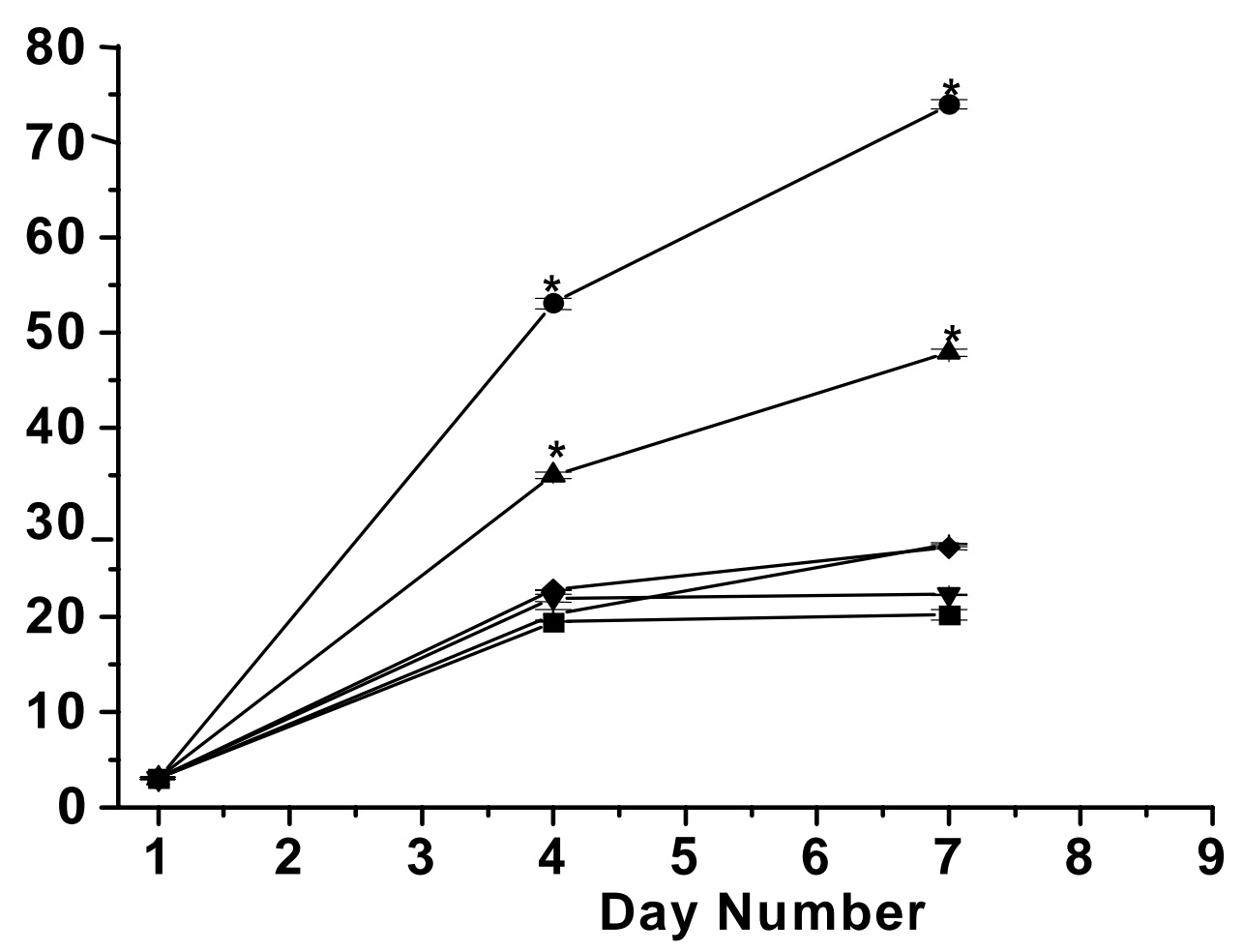




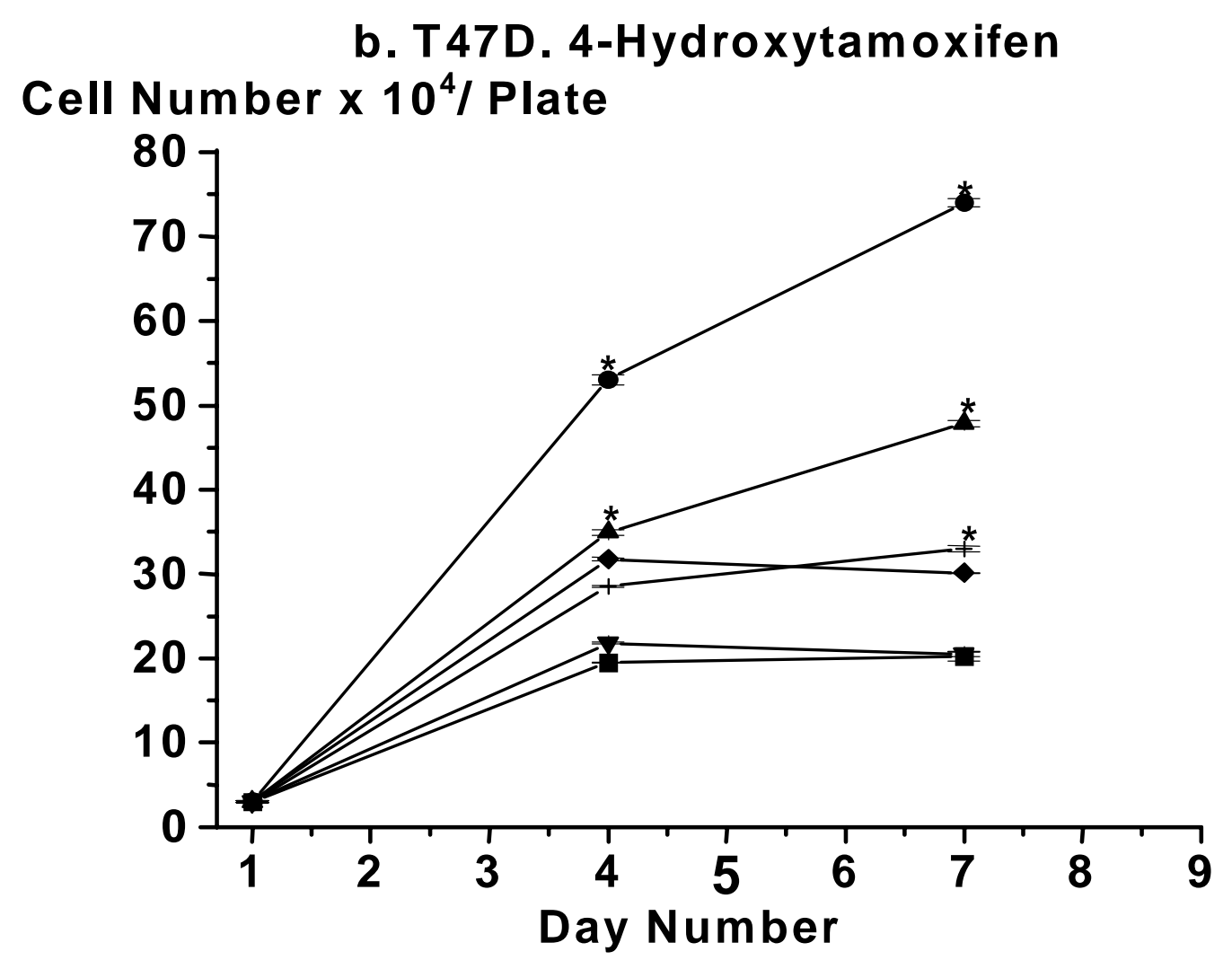

Figure 3.13 Effects of (a) ICI 182,780 and (b) 4'-hydroxytamoxifen on acetaminopheninduced T47D cell proliferation. Cells were treated as in Figure 5; Treatments in (a) are: (ם)

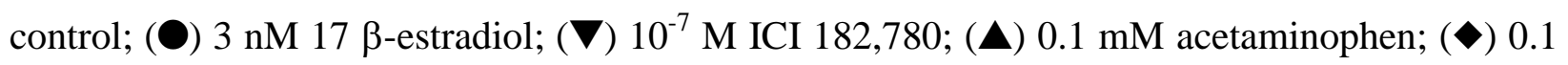
$\mathrm{mM}$ acetaminophen $+10^{-8} \mathrm{M}$ ICI 182,780; ( | ) 3nM estradiol $+10^{-7} \mathrm{M}$ ICI 182,780. Treatments

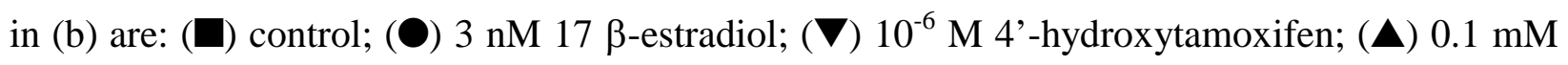
acetaminophen; (|) $3 \mathrm{nM}$ estradiol $+10^{-6} \mathrm{M}$ 4'-hydroxytamoxifen; $(\bullet) 0.1 \mathrm{mM}$ acetaminophen + $10^{-6} \mathrm{M}$ 4'-hydroxytamoxifen; “*” indicates statistically significant differences relative to control. 


\subsubsection{ER Binding Assays}

Evidence points to ERs involvement in acetaminophen-induced proliferation. The obvious question then was whether acetaminophen mimics estradiol and binds to ER. Because high specific activity radiolabeled acetaminophen is not available to determine direct binding to ER, indirect experiments (competition) were done to answer this question. In addition, two important factors have been reported to modulate weak xenoestrogen activity: time of incubation and presence of serum in media (Nagel et al., 1998). Thus, experiments were done in whole cells at 45 minutes and 18 hours and + or - serum (FBS) to maximize the conditions under which even weak estrogens can be detected (Nagel et al., 1998).

Figure 3.14 shows that a $10^{7}$-fold molar excess of acetaminophen did not compete with estradiol for binding ERs in MCF7 cells after 18 hours. The removal of FBS and the increase in incubation time to 18 hours are changes supposed to improve detection of even weak xenoestrogens (Nagel et al., 1998). However, acetaminophen did not compete with estradiol for binding ERs in MCF7 cells at 18 hours nor was there any significant increase in acetaminophen binding to ER if the FBS was absent or present. Thus, it appears that acetaminophen does not bind to ER at the same site at which estradiol binds in whole breast cancer cells. 


\section{MCF7 cells. Influence of FBS on specific binding}

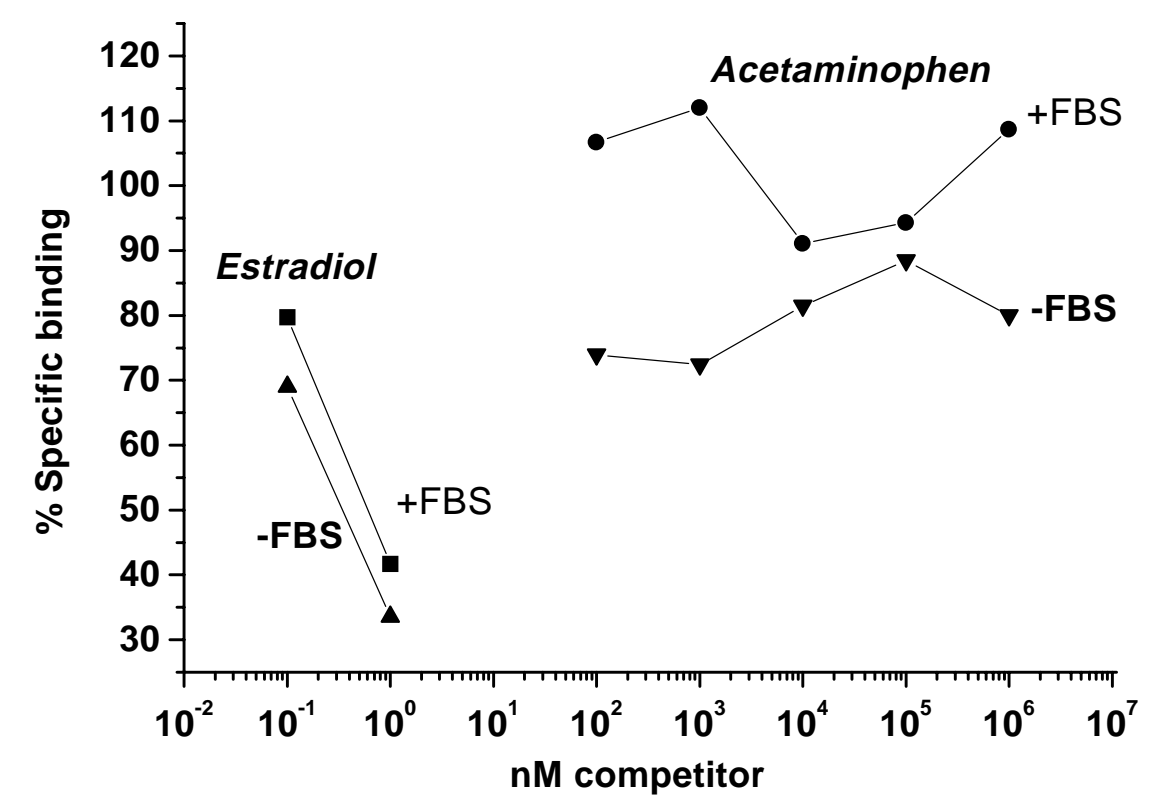

Figure 3.14 Acetaminophen does not compete with estradiol for binding estrogen receptors in MCF7 cells. Cells were plated in 6 well plates and depleted of estrogen. Then media with ${ }^{3} \mathrm{H}-$ estradiol $(0.1 \mathrm{nM}) \pm 0.1-10 \mathrm{nM}$ estradiol or $\pm 0.1 \mu \mathrm{M}$ - $1 \mathrm{mM}$ acetaminophen were added for 18 hours to determine ${ }^{3} \mathrm{H}$-estradiol total binding. Additional plates were treated with ${ }^{3} \mathrm{H}$-estradiol $(0.1 \mathrm{nM})+$ $600 \mathrm{nM}$ excess estradiol to determine nonspecific binding. Specific binding was determined by subtracting nonspecific from total binding (see details in methods section). Representative results are shown and depict \% specific binding by $0.1 \mathrm{nM}{ }^{3} \mathrm{H}$-estradiol in the presence of competing estradiol $(\mathbf{\Lambda}, \mathbf{\square})$ or acetaminophen $(\bullet, \mathbf{)})$ and $+(\square)$ or $-(\mathbf{\Lambda})$ FBS. 


\subsubsection{Acetaminophen Isomers Studies}

The question addressed in these experiments is whether the position of the phenolic substituent is a structural feature of acetaminophen that determines its activity as a proliferation stimulator. As mentioned, such hypothesis is based on suggestions that the phenol moiety oriented in the para position is important for chemicals to display estrogenicity (Cunningham et 1997; Anstead et al., 1997). Therefore, the positional isomers of acetaminophen, the $p-, m$ - and $o$ acetamidophenol were evaluated to determine if all, some, or only acetaminophen ( $p$ acetamidophenol) induces proliferation. In Figure 3.15a, the effects of the acetaminophen positional isomers $(0.1 \mathrm{mM})$ on T47D cell proliferation are compared. At day 6 , relative to control cell number, $p$-acetamidophenol increased proliferation 1.6-fold, $m$-acetamidophenol increased proliferation 1.2fold, while $o$-acetamidophenol had no effect on cell number; $3 \mathrm{nM}$ estradiol increased proliferation 2- fold. Figure 3.15b shows the effects of the 3 isomers on proliferation of a different estrogenresponsive, breast cancer cell line, MCF7. Relative to control cell numbers on day $6, p$ acetamidophenol increased proliferation 1.7-fold, $m$-acetamidophenol increased proliferation 1.4fold, while $o$-acetamidophenol had no effect on proliferation; estradiol induced proliferation 2.5fold. 

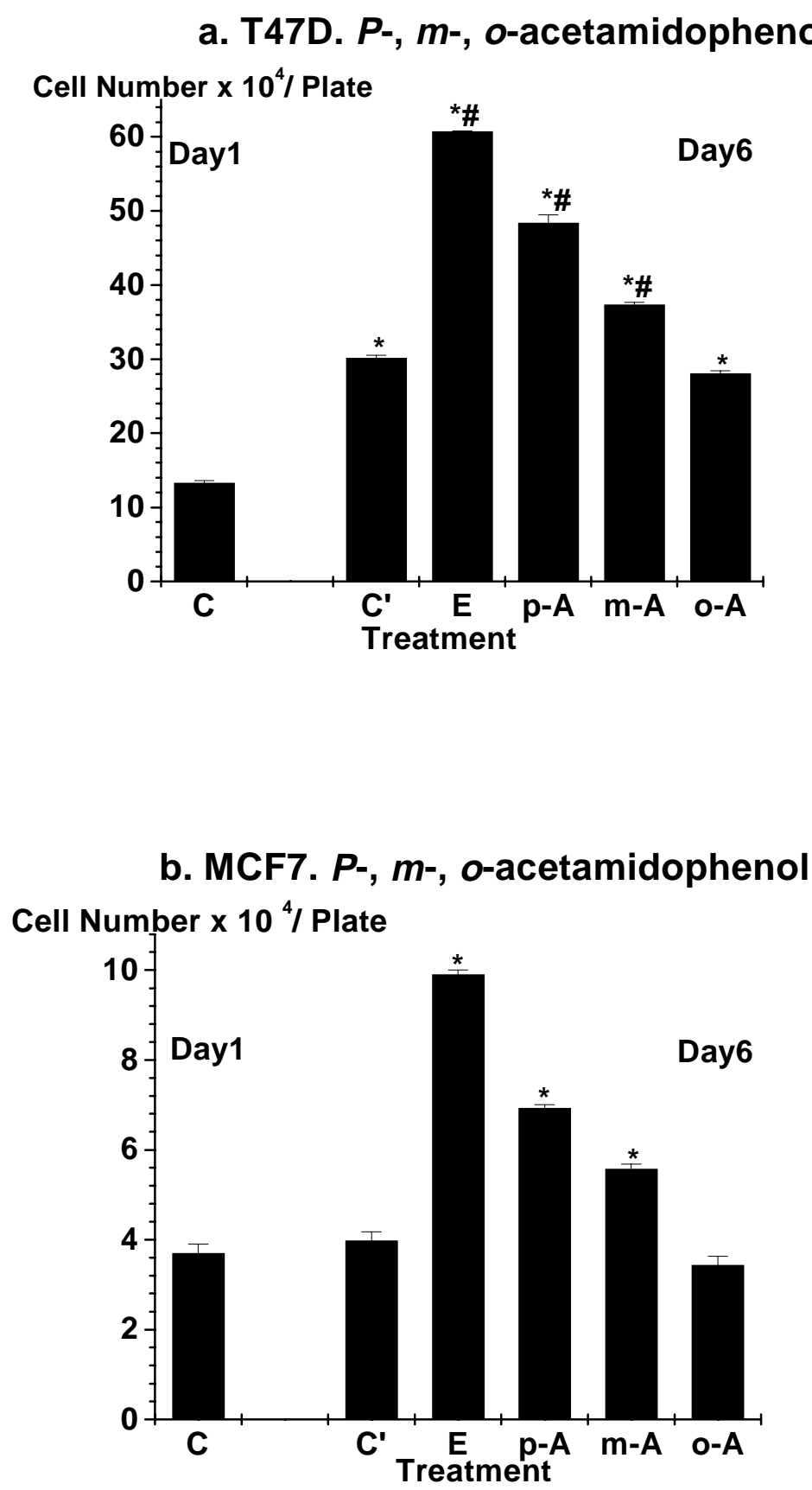

Figure 3.15 Effects of acetaminophen positional isomers on T47D (a) and MCF7 (b) cell proliferation. Cells were treated as described in Figure 1 with $3 \mathrm{nM}$ estradiol (E) or with: (a) $0.1 \mathrm{mM} o-, m-, p$-acetamidophenol (A) or (b) $0.3 \mathrm{mM} o-, m$-, $p$-acetamidophenol (A). C indicates 
number of cells initially plated and receiving vehicle. After six days and two exposures to acetaminophen or estradiol, cells were counted in a hemocytometer; $\mathrm{C}^{\prime}$ indicates number of cells in cultures receiving only vehicle for 6 days; “*” indicates statistically significant differences from control; "\#” indicates statistically significant differences from estradiol. 


\subsection{Acetaminophen Metabolism in Microsomal Preparations}

The objective this study was to determine if acetaminophen metabolism could be detected in breast cancer cell microsomes. The study of microsomes was necessary because when whole cells were analyzed, no metabolites could be detected (Miller and Siegel, unpublished data). A positive control in these experiments was Arochlor-induced rat S9. Non-induced human liver microsomes were also tested. As anticipated, the cysteine-acetaminophen peak produced by the metabolism of acetaminophen via the cytochrome P450 mediated path, eluted at 7.7 minutes and was well resolved from the parent acetaminophen peak which eluted at 10.3 minutes (Zaher et al., 1998). The limit of detection of the HPLC was 5 pmoles in $100 \mu$ sample injected into the column. Figure 3.16 shows that the acetaminophen-cysteine conjugate was formed in greatest amounts by S9 derived from Arochlor-induced rat liver samples. The acetaminophen-cysteine conjugate was also formed by non-induced human liver microsomes but in lower amounts. In MCF7 cell samples, the acetaminophen-cysteine (Ac-Cys) conjugate was not detected in samples from cells treated with medium alone or with acetaminophen. However, the acetaminophencysteine metabolite was detected in small amounts in microsomes prepared from MCF7 cells induced with TCDD or BNF. The acetaminophen-cysteine metabolite was also formed by microsomes from MDA-MB-231 cells pretreated with BNF or acetaminophen. 


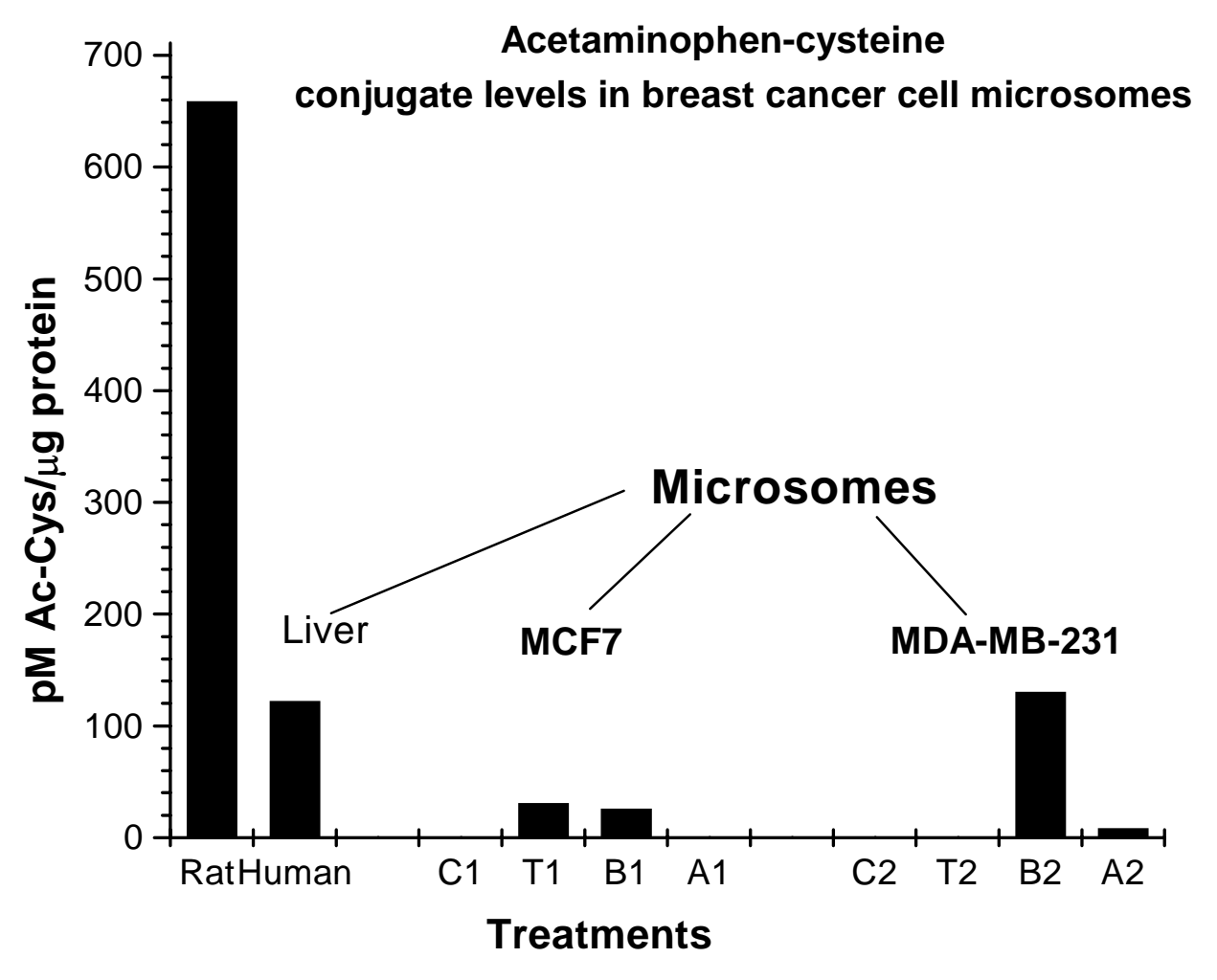

Figure 3.16 Acetaminophen metabolites from breast cancer cells microsomes. Samples were prepared and analyzed as described in methods. Rat=rat S9 induced with Arochlor; Human=human liver microsomes, noninduced; 1=MCF7; 2=MDA-MB-231; C=control microsomes from cells treated with estrogen-free medium; $\mathrm{T}=$ microsomes from 10nM TCDD treated cells; $\mathrm{B}=$ microsomes prepared from cells treated with $40 \mu \mathrm{M}$ beta-naphthoflavone; $\mathrm{A}=$ microsomes from cells treated with $0.1 \mathrm{mM}$ acetaminophen. Cell treatments were for 24 hours ( $\mathrm{n}=2$ for MDA- MB-231 cells; $\mathrm{n}=1$ for MCF7 cells). 


\subsection{Tumor Growth}

The goal of these studies was to assess the effects of acetaminophen on ER+, MCF7 tumors in nude mice. Following the implantation of MCF7 cells in the breast fat pads of ovariectomized nude mice, small tumors were observed. Relative to tumors in control animals, the tumors in the ovariectomized nude mice treated with estradiol $(\mathrm{E})$, estradiol + acetaminophen $(\mathrm{E}+\mathrm{A})$ and acetaminophen (A) increased in size by day 36 as shown in Figure 3.17. However, all tumors regressed to levels that could not be measurable on day 44 .

\section{Day 36}

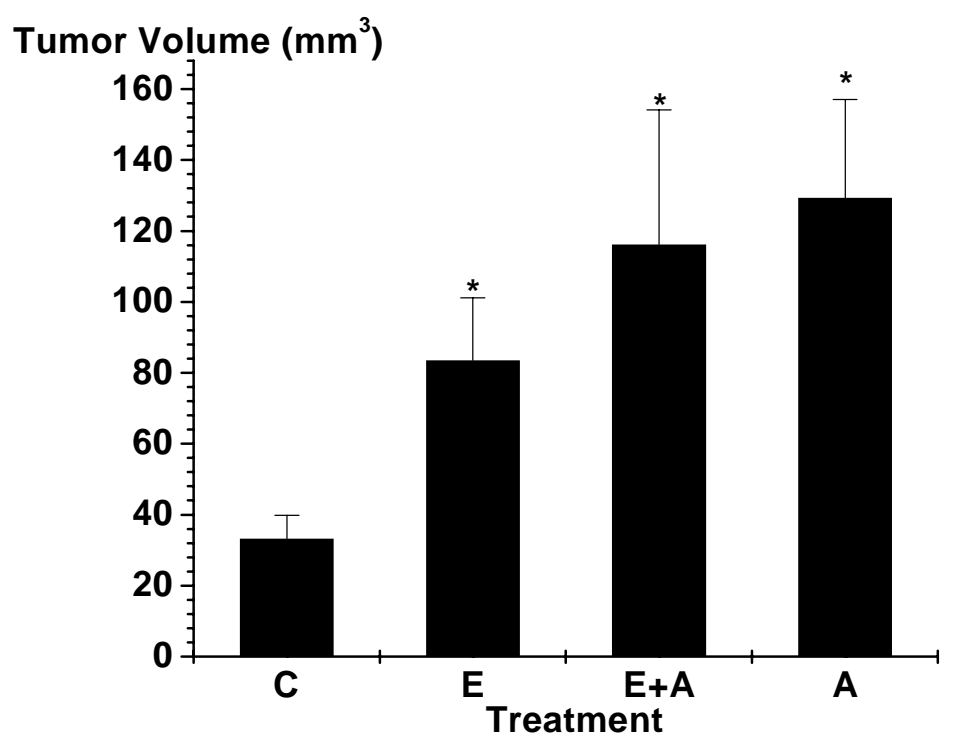

Figure 3.17 Acetaminophen stimulates MCF7 tumor growth in nude mice by day 36. Treatments are as described in the methods section. 
Because a previous study conducted by Cramer et al. (1998 b) indicated that acetaminophen can affect plasma estradiol levels in women, plasma estradiol levels were measured in this study as well. Samples from day 44 were collected and estradiol levels were: control $11.6 \pm 0.2$; acetaminophen $8.5 \pm 0.9 ;$ estradiol $155 \pm 31 ;$ estradiol + acetaminophen $166 \pm$ $0 \mathrm{pg}$ estradiol/ml. 


\subsection{Data Summary}

Acetaminophen induces proliferation in ER+/PR+ breast cancer cells but not in ER-/PR+ or ER-/PR- breast cancer cells or in normal breast cells. A summary of the types of cells stimulated by acetaminophen is shown below.

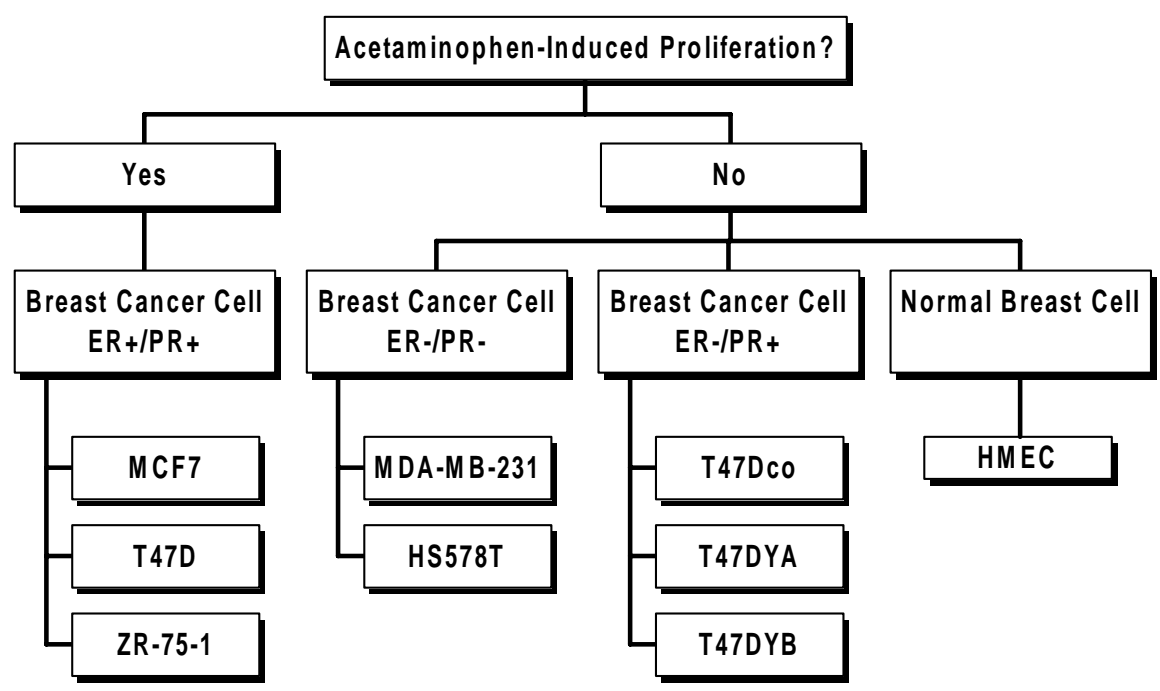

Proliferation Acetaminophen vs. Estradiol

\begin{tabular}{|l|c|c|}
\hline \multicolumn{1}{|c|}{ Chemical } & Acetaminophen & Estradiol \\
\hline Effect & Similarities \\
\hline $\begin{array}{l}\text { Selective } \\
\text { proliferation } \\
\text { (ER+/PR+)? }\end{array}$ & yes & yes \\
Involve ER? & Probably yes & yes \\
\hline \multicolumn{3}{|c|}{ Differences } \\
\hline $\begin{array}{l}\text { Potency? } \\
\text { Acetaminophen vs Estradiol }\end{array}$ & low & high \\
\hline
\end{tabular}


These data indicate that acetaminophen-induced proliferation may involve ER. Further support to this conclusion comes from studies showing that acetaminophen-induced proliferation can be inhibited by antiestrogens. From this point of view, acetaminophen mimics estradiol. However, acetaminophen does not compete with estrogen for binding to ER. From this point of view, acetaminophen does not mimic estradiol. Another difference between acetaminophen and estradiol is that acetaminophen is much less $\left(10^{5}\right)$ potent (but pharmacologically relevant) than estradiol. These conclusions are summarized in the table below.

\section{ER Involvement}

\begin{tabular}{|c|c|c|}
\hline $\begin{array}{l}\text { Chemical } \\
\text { Effect }\end{array}$ & Acetaminophen & Estradiol \\
\hline & \multicolumn{2}{|c|}{ Similarities } \\
\hline Antiestrogen $\otimes$ ? & yes & yes \\
\hline ER involved? & yes & yes \\
\hline & \multicolumn{2}{|c|}{ Differences } \\
\hline $\begin{array}{l}\text { Sensitivity to } \otimes \text { ? } \\
\text { (Acetaminophen vs Estradiol) }\end{array}$ & high & low \\
\hline ER binding? & no & yes \\
\hline
\end{tabular}

Where: $\otimes=$ inhibition. 
Consequently, although acetaminophen and estradiol share some similarities in stimulating ER+ breast cancer cell proliferation, the mechanisms by which these compounds act appear different. In addition, acetaminophen metabolism is not detected in MCF7 breast cancer cell microsomes unless cells are pretreated with TCDD or BNF. 


\section{CHAPTER IV. DISCUSSION}

Most studies of acetaminophen have shown that this drug has inhibitory and/or toxic effects on various tissues and cells. A strong criticism, however, is that most in vitro studies showing such inhibitory effects have been conducted at unrealistically high acetaminophen concentrations, well above intoxication levels that would lead to death in humans. Many in vivo studies that show inhibitory effects have also used doses of acetaminophen that are well above intoxication levels in humans. Thus, it is important to place the relevance of such findings in perspective. This report is novel and demonstrates that concentrations of acetaminophen achieved in plasma following administration of pharmacological doses of acetaminophen selectively stimulate estrogen-responsive human breast cancer cell proliferation. This conclusion is based on the observation that acetaminophen stimulated proliferation in three different ER+ breast cancer cells but did not in two ER- breast cancer cells. The importance of testing multiple ER+ and ER- cell lines is illustrated by the report that $\beta$-sitosterol stimulates T47D but not MCF7 breast cancer cell proliferation (Mellanon et al., 1996). Furthermore, using different breast cancer cell lines is likely to more accurately represent the in vivo heterogeneity of cells.

The concentrations of acetaminophen used in this study reflect therapeutic and toxic levels achieved in humans. The typical therapeutic adult dose of acetaminophen is $0.325-1.3 \mathrm{~g}$ administered every 4-6 hours (Kastrup, 1981), resulting in plasma concentrations of approximately 0.03-0.12 mM (Forrest et al., 1982). Doses over $10 \mathrm{~g}$ are toxic (Kastrup, 1981) and lead to plasma concentrations of approximately $1 \mathrm{mM}$ (Jensen et al., 1996). 
In addition to testing multiple ER+ and ER- cell lines, three different endpoints were tested: ${ }^{3} \mathrm{H}-\mathrm{dT}$ incorporation into DNA, \% $\mathrm{S}$ phase cells and cell numbers. These endpoints provided consistent responses of ER+/PR+, ER-/PR+ and ER-/PR- cells tested to both acetaminophen and estradiol. Concentrations of 0.1-0.3 $\mathrm{mM}$ acetaminophen stimulated ${ }^{3} \mathrm{H}-\mathrm{dT}$ incorporation into DNA, \% S phase cells, and cell numbers only in the ER+/PR+ cell lines. The $\mathrm{ER}+/ \mathrm{PR}+$ cell lines were similar in that they all exhibited acetaminophen- and estradiol-induced proliferation. However, the magnitude of the acetaminophen- relative to the estradiol-induced response varied somewhat in different experiments and among the different ER+ cell lines. Part of this variation may be attributed to differences among endpoints measured and to inherent differences among the three $\mathrm{ER}+/ \mathrm{PR}+$ cell lines (distribution of receptor subtypes, origin of cell lines, etc.).

These results suggest that ERs may be involved in mediating acetaminophen-induced proliferation of $\mathrm{ER}+/ \mathrm{PR}+$ breast cancer. In contrast, acetaminophen does not induce proliferation of breast cancer cells that are ER-/PR- or of cells that are deficient in ERs but have high PR levels. For example, acetaminophen does not induce proliferation in T47Dco cells. These cells have PRA-PRB heterodimers and PRA and B homodimers; they also have low levels of wild type and mutant ER's. These data could be interpreted to mean that acetaminophen, like estradiol may not bind to ER mutants that have alterations in the ligand binding domain (as in T47Dco cells) and/or that ER levels are too small for a weak agonist such as acetaminophen to elicit any estrogenic effects. In addition, since some inhibitory activity is displayed in T47DYB 
cells by acetaminophen at high concentrations PRB homodimers may be involved in acetaminophen-induced inhibition of proliferation in these T47DYB cells. Second, acetaminophen-induced proliferation of $\mathrm{ER}+/ \mathrm{PR}+$ cells is inhibited by both a pure antiestrogen, ICI 182,780 and by a partial antiestrogen, 4'-hydroxytamoxifen. Our results are consistent with other studies demonstrating that ICI 182,780 is a more potent inhibitor of estradiol-induced proliferation than is 4'-hydroxytamoxifen (Osborne et al., 1995, Branham, 1996). ICI 182,780 is also a more potent inhibitor of acetaminophen-induced proliferation than is 4'-hydroxytamoxifen and acetaminophen-induced proliferation is more sensitive to ICI 182,780 inhibition than is estradiol-induced proliferation. These results support a role of ERs in mediating acetaminopheninduced proliferation.

On the other hand, acetaminophen does not compete with estradiol for binding ERs in MCF7 cells. Collectively, these data suggest that acetaminophen- and estradiol-induced proliferation of breast cancer cells both involve ERs. However, while estradiol binds ERs, acetaminophen does not bind to the same site to which estradiol binds in the type of assays conducted in these studies. The ERalpha rather than indicating a pathway of acetaminophen action may instead represent a "biomarker" of cell types that may undergo acetaminopheninduced stimulation of proliferation. Alternatively, the ERalpha requirement for acetaminophen stimulatory effects may indicate an indirect pathway. Antiestrogens inhibit not only the ERs directly but also some growth factors and their receptors (e.g., TGFalpha) while stimulating growth inhibitory factors and their receptors (e.g., TGFbeta); these factors exert autocrine effects on ER+ cells (Katzenellenbogen et al., 1997). Thus, the antiestrogen inhibition of 
acetaminophen-induced proliferation in ER+ breast cancer cells may mean that such growth factors may be directly involved while ER may be only indirectly involved in the mechanism of acetaminophen action. Examples of substances that do not directly bind to ERs but influence ERs indirectly and ultimately lead to proliferation of breast cancer cells include environmental compounds such as o, p'-DDT, and endogenous compounds such as growth factors and neurotransmitters (Katzenellenbogen, 1997; DeCupris and Favoni, 1997; Smith, 1998; Enan and Matsuma, 1998). In addition, this alternative, ligand-independent mechanism of proliferation that does not involve direct binding of ligand to ERs usually involves modulation of kinases and/or phosphatases by estrogens/antiestrogens. For example, epidermal growth factor does not directly bind to ERs to stimulate proliferation of breast cancer cells. Instead, EGF binds its own plasma membrane receptors, event that subsequently leads to activation of the MAPK cascade that ultimately influences the transcriptional activation of ER and proliferation of some ER+ cells such as breast cancer cells (Smith, 1998). Other compounds can stimulate other kinases such as protein kinases $\mathrm{A}$ (PKA) and $\mathrm{C}$ (PKC) or tyrosine kinases (TK) and such compounds lead to stimulation of proliferation of breast cancer cells. Conversely, compounds that inhibit kinases such as PKC (e.g., tamoxifen) inhibit proliferation of breast cancer cells (DeCupris and Favoni, 1997, Katzenellenbogen, 1997). In addition, compounds such as okadaic acid stimulate proliferation of breast cancer cells by inhibiting protein phosphatases (Smith, 1998). Thus, acetaminophen may modulate proliferation of breast cancer cells by modulating kinases/phosphatases. In fact, from a mechanistic standpoint, acetaminophen may mimic growth factors rather than estradiol in ER+ breast cancer cells and estradiol may not be the best model for acetaminophen in these cells. 
In summary, it is possible that acetaminophen may alter breast cancer cells by altering Hsp90-ER interaction, ER conformation, ER phosphorylation status, kinases or phosphatases activity or levels, and/or ER cofactor/regulator levels/availability. In alternative pathways, estradiol upregulates some growth factors and their receptors, leading to autocrine stimulation of proliferation; some antiestrogens inhibit this pathway (DeCupris and Favoni, 1997). Acetaminophen may act indirectly via such a pathway that crosses the ER pathway. A simplified representation of the mechanisms by estradiol, xenoestrogens, and growth factors may induce proliferation in ER+ cells is shown below. 


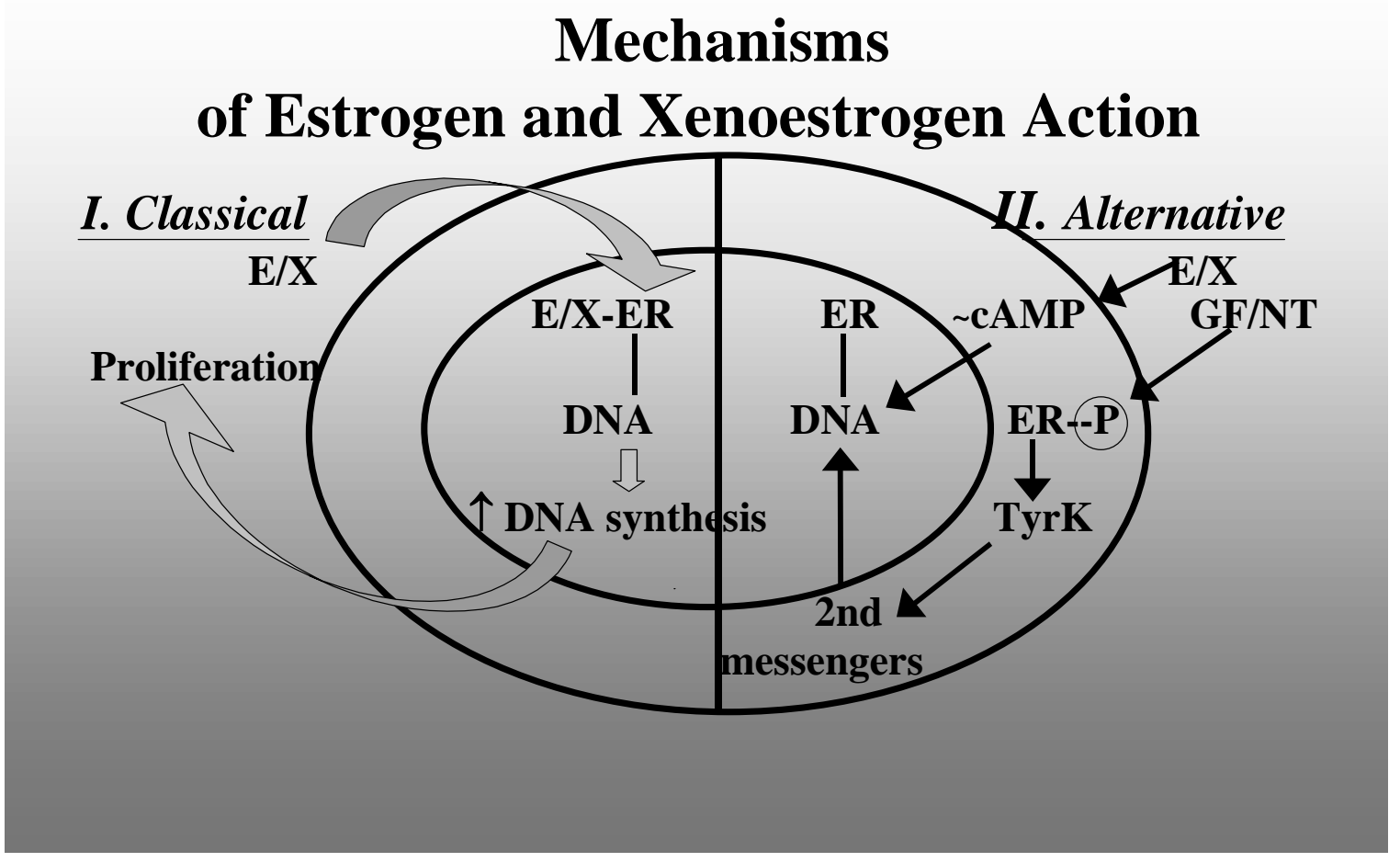

Where:

$\mathrm{E}=$ estradiol/estrogens

$\mathrm{X}=$ xenoestrogens

$\mathrm{ER}=$ estrogen receptors

$\mathrm{GF}=$ growth factors

$\mathrm{NT}=$ neurotransmitters

ER-P $=$ phosphorylated estrogen receptors 
TyrK = tyrosine kinases/kinases

It would possible to test the involvement of some of these alternative pathways or components of these pathways in acetaminophen-induced proliferation. For example, similar to the experiments in which antiestrogens were used to test for the involvement of ERs in proliferation, one could test for the involvement of phosphorylation. The effects of tyrosine kinase and mitogen activated protein kinase (MAPK) inhibitors, such as geldanamycin on acetaminophen-induced breast cancer cell proliferation could be established. The effect of protein phosphatase inhibitors, such as okadaic acid, on acetaminophen-induced proliferation of breast cancer cells could also be established. Inhibition of proliferation by protein kinase inhibitors would suggest involvement of protein kinases in acetaminophen-induced proliferation. Inhibition of proliferation by protein phosphatases would suggest involvement of protein phosphatases in acetaminophen-induced proliferation.

There are clear similarities, as well as differences, between breast cancer cell proliferation induced by acetaminophen and $17 \beta$-estradiol. There are major similarities between acetaminophen- and $17 \beta$-estradiol-induced proliferation. These include: (1) both compounds induce proliferation in $\mathrm{ER}+/ \mathrm{PR}+$ human breast cancer cells with high ER levels; (2) neither compound induces proliferation in breast cancer cells with low ER and high PR levels or in ER/PR- breast cancer cells; and (3) both compounds induce proliferation that is inhibited by antiestrogens. Thus, from this perspective, acetaminophen acts like an estrogen. Differences between acetaminophen and $17 \beta$-estradiol include: (1) effects on cells other than breast cancer cells (e.g., fish liver cells where estrogen has estrogenic activity while acetaminophen has 
antiestrogenic activity); (2) potency of these compounds in inducing proliferation in breast cancer cells; and (3) mechanism of breast cancer cell proliferation induction.

This study shows that T47D and MCF7 breast cancer cells undergo proliferation in response to $p$-acetamidophenol, the isomer found in medication. The relative potency of the 3 acetamidophenol isomers is $p>m>o \approx$ control. The fact that the positional isomers of acetaminophen ( $m$ - and $o$-acetamidophenol) were less potent than acetaminophen $(p$ acetamidophenol) suggests that the $-\mathrm{OH}$ position on the benzene ring is an important element within the chemical structure of acetaminophen that determines the extent to which proliferation is induced in the studied system. These findings are consistent with previous studies that have shown $p$-phenols have estrogenic activity and are more potent proliferation inducers in cultured breast cancer cells than their $m$ - and $o$-isomers (Soto et al., 1991).

Acetaminophen appears to have estrogenic effects in one system, e.g., increasing proliferation in ER+ human breast cancer cells (Harnagea-Theophilus and Miller, 1998). On the other hand, acetaminophen has antiestrogenic effects in another system, e.g., decreasing vitellogenin production in trout liver cells (Miller et al., 1999) or has no estrogenic effects in other systems, e.g., no increase in rodent uterine weight (Harnagea-Theophilus et al., 1999). Thus, acetaminophen displays a spectrum of effects from stimulation to inhibition of various estrogenic responses. These findings are consistent with other reports in which a single compound was found to exert estrogen agonistic or antagonistic effects depending on the species and tissue on which it acts. For instance, betulin and pinosylan elicit estrogenic effects 
in human breast cancer cells but not in trout liver cells (Mellanon et al., 1996) while raloxifene exhibits antiestrogenic effects in human breast but estrogenic effects in human bone (Penissi, 1997).

First, these observations suggest that acetaminophen mimics some of estradiol effects, and this mimicry is cell-type specific or selective. Second, like many other exogenous compounds with selective estrogenic action, acetaminophen is $10^{5}$ less potent than estradiol in inducing proliferation in breast cancer cells. Although acetaminophen is much less potent than estradiol, the concentrations that stimulate breast cancer cell proliferation are pharmacologically relevant. Third, the mechanism of acetaminophen-induced proliferation appears to be different from that of estradiol-induced proliferation. While estradiol binds ERs in MCF7 cells, acetaminophen does not. Similar patterns of differences in effects and mechanisms of action between estradiol and other estrogenic phenols, such as bisphenol A, have recently been reported (Gould et al., 1998). For example, unlike estradiol, bisphenol A had no effect on uterine weight; however, like E2, it induced PR levels, though not to the level induced by estradiol. Thus, many of the compounds that are lately found to mimic estrogen action, mimic this action selectively or partially, not totally, depending on the tissue studied and the endpoint monitored.

The variety of effects acetaminophen exerts in different estrogen-responsive tissues may be attributed to differences in distribution of estrogen receptors subtypes in different tissues; differences in acetaminophen concentrations used in different studies; differences in metabolism in different tissues; and/or differences in species (human, rodent, fish) used in 
different studies. Indeed recent findings of other ER subtypes help interpret such apparently paradoxical effects. For example, MDA-MB-231 breast cancer cells were shown to be ER $\alpha$ /ER $\beta+$ cells and in these cells both wild type and variant ER $\beta$ (exon 5 deleted; impaired hormone binding domain function) are present. If it is assumed that acetaminophen acts via ER's at all, then in order for it to elicit estrogenic effects at least in breast cancer cells, it may need either only ER $\alpha$ present (as in ZR-75-1 cells) or a mixture of ER $\alpha$ and $\beta$ hetero/homodimers in which $\alpha \geq \beta$ (as in MCF7 or T47D cells).

It is noteworthy that many systems inhibited by acetaminophen contain ER $\beta$. The antiestrogenic effects of acetaminophen may be mediated by this receptor subtype in cells with only the $\beta$ subtype or in which $\beta$ is predominant over $\alpha$. For example, trout ER is an analogue of human ER $\beta$, and ER in ovaries are mainly $\beta$ (with human granulosa cells only $\beta$ ). By contrast, normal breast tissue and ER+ breast cancer tissue, with some exceptions, usually has ER $\alpha \geq \beta$ (Enmark et al., 1997). Moreover, the ER $\beta$ subtype in breast appears dependent on ER $\alpha$ but not vice versa, because in ER $\alpha$ - mice, the breast is absent (thus both $\alpha$ and $\beta$ ) while ER $\beta$ - mice develop normal breasts. The breast, thus, may have its unique ER $\alpha-\beta$ interactions, different from other reproductive organs but consistent with its own function.

Acetaminophen appears stimulatory to initial stages of MCF7 tumor growth in ovariectomized nude mice. However, it must be understood that this was only a preliminary experiment that needs to be validated. The main problem with the in vivo experiment was that 
most tumors regressed (including the positive controls) by day 44 . This could have been due to improper inoculation/pellet implant in some of the mice, although all tumors developed initially. Alternatively, although these mice are immunospuressed, the suppression is not total but partial. In fact these mice have more natural killer cells than normal mice of similar backgrounds do. Thus, it is possible that the tumors regressed partly because of the involvement of the remaining immunity. In addition, since this experiment was done once, no clear conclusions can be drawn regarding this effect in vivo. It is possible that acetaminophen may initially stimulate and then inhibit tumor growth, if this experiment is reproducible.

The nude mice study also indicates that acetaminophen may affect estradiol levels in vivo. Estradiol levels were reduced from $11.6 \pm 0.2 \mathrm{pg} / \mathrm{ml}$ in controls to $8.5 \pm 0.9 \mathrm{pg} / \mathrm{ml}$ in acetaminophen-treated mice, indicating that acetaminophen may lower estradiol levels produced by tissues other than ovaries. These findings are consistent with a recent report (Cramer et al., $1998 \mathrm{a}, \mathrm{b})$ that estradiol levels were significantly reduced by acetaminophen in women over 34 years of age. Cramer et al., 1998 a, b suggested that this characteristic of the estradiolacetaminophen interaction might offer protection against estrogen-dependent cancers in humans.

It was not possible to detect acetaminophen metabolism in microsomes form MCF7 cells unless cells were pretreated with TCDD or with BNF to induce cytochrome P450. Although the metabolism of acetaminophen is not detectable in this assay in the absence of induced cytochrome P450, we cannot say that it is unimportant. It remains to be determined whether the parent compound or a metabolite of acetaminophen causes proliferation in 
$\mathrm{ER}+/ \mathrm{PR}+$ breast cancer cells. It would be easy and logical to test the effects of acetaminophen metabolites directly on proliferation. Unfortunately, these metabolites are not commercially available, thus, such experiments could not be conducted.

In vivo, there are 2 major pathways involved in the metabolism of acetaminophen (see next figure). There is a detoxification pathway (involved when therapeutic doses of acetaminophen are administered) and a toxication pathway (involved when toxic doses of acetaminophen are administered and detoxication pathways are saturated). 


\section{Acetaminophen Metabolism}

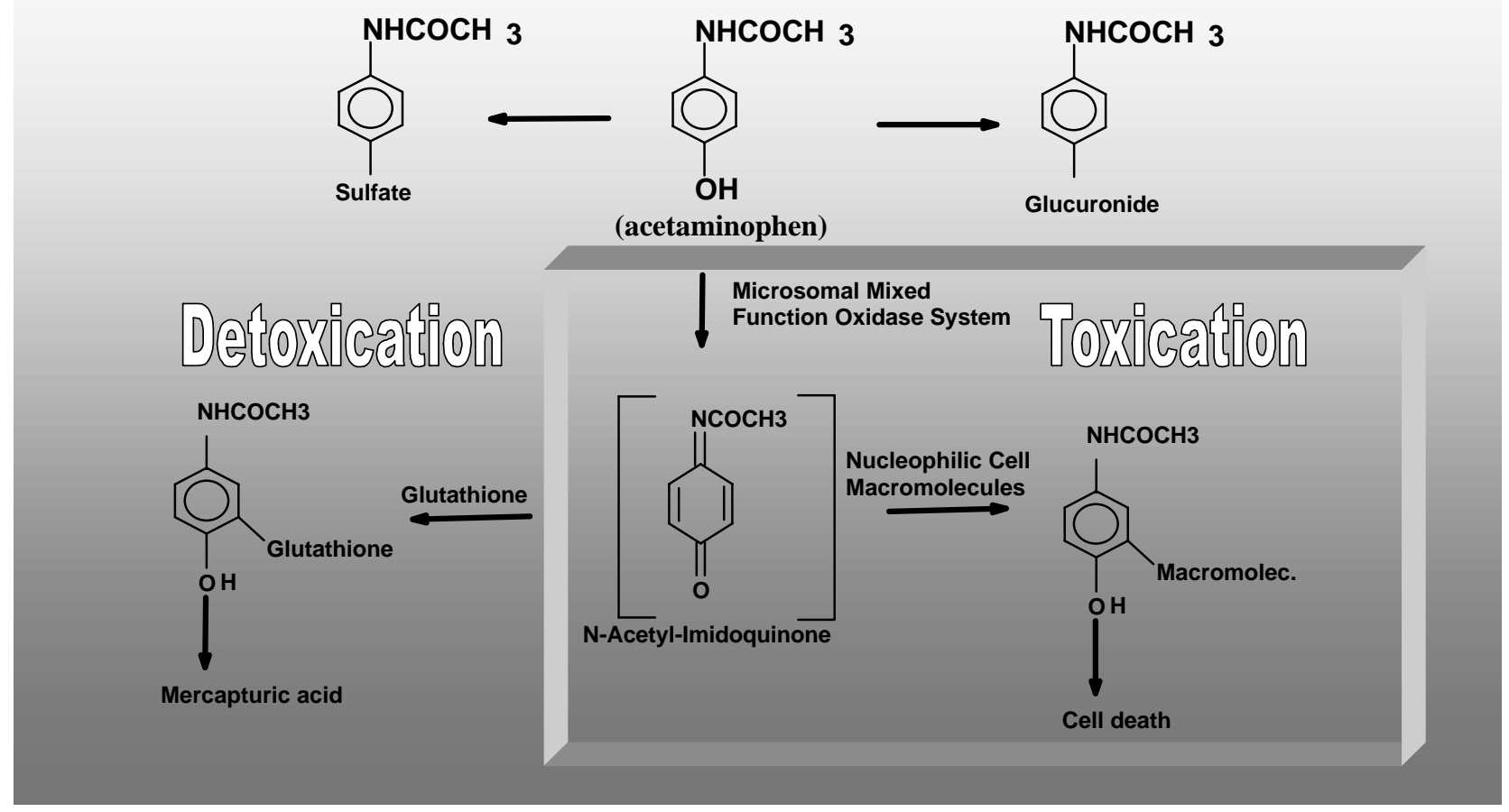

In the detoxication pathway, paracetamol metabolizes into readily excreted compounds. In most species, glucuronide and sulfate metabolites are major metabolites, constituting 70-90\% of the total conjugates excreted (Prescott, 1996), while cysteine and mercapturic acid conjugates are minor metabolites. In addition, approximately $3 \%$ of the parent compound is excreted unchanged. Formation of glucuronide conjugates is catalyzed by glucuronosyl transferases while formation of sulfate conjugates is catalyzed by sulphotransferases (Prescott, 1996). Sulphate conjugation is a major, parallel route of detoxication, inversely correlated with glucuronide conjugation. The enzymes catalyzing the sulfation reaction include cytosolic, ubiquitous aryl and, depending on the concentration of 
paracetamol used, different enzyme isoforms are involved in catalysis (Prescott, 1996). Glutathione-S-transferase catalyzes the formation of $m$-GSH conjugates and the resulting metabolites are almost exclusively excreted into bile. Paracetamol has low affinity for GSH conjugation, and the process is not readily saturated even at high concentrations $(10-25 \mathrm{mM}$ or 1500-3800 mg/l) (Prescott, 1996). Regarding the distribution of GSH conjugates, concentrations of GSH metabolites in tissues other than liver are very low.

The percent glucuronide formed in various species spans a broad range. Glucuronide metabolites comprise $50-60 \%$ of dose in man while $25-35 \%$ of acetaminophen is metabolized to sulfate conjugates (Prescott, 1996). In humans, small oral doses of paracetamol $(<40 \mathrm{mg} / \mathrm{kg})$ can lead to excretion of $\sim 11 \%$ as cysteine and mercapturic acid conjugates and the paracetamol cysteine conjugate is $2-5 \%$ in man (Prescott, 1996). However, the relative percentage of glucuronide and sulphate conjugates varies greatly with many factors, including dose magnitude, dosing regimen, age, animal strain, gender, concomitant drug use (e. g., oral contraceptives), lifestyle (e.g., smoking), and disease state (e.g., glucuronosyl transferase deficiency states as in Gilbert's diseases).

The intoxication pathway is activated when toxic doses of paracetamol are administered. In that situation, glucuronidation, sulfation, and glutathione conjugation cannot keep up with the high dose of drug that needs conjugated. Glutathione (GSH) is consumed increasingly and when levels fall under 20-40 \% of total glutathione, then the GSH pathway cannot effectively detoxify the excess of intermediary reactive metabolite formed. The reactive metabolite 
arylates cell macromolecules instead of conjugating with GSH, leading to toxic effects especially in paracetamol target organs that accumulate high concentration of paracetamol, the liver and kidneys. The intermediate, $\mathrm{N}$-acetamidoquinone, can function as both an oxidant and an electrophile (Miners and Kissinger, 1979). The intermediate is moderately stable and can react with nucleophiles (cysteine, $\mathrm{N}$-acetylcysteine, GSH) to reversibly form paracetamol or the corresponding thiol adducts (Dahlin, 1984). Spontaneous reactions lead to formation of the glutathione conjugate, paracetamol, and GSH.

Is it plausible that acetaminophen conjugates may stimulate proliferation of breast cancer cells in vivo? Metabolites such as glucuronide and sulfate conjugates are large and much more hydrophilic than the parent compound, so that, in vivo, they facilitate excretion of acetaminophen. In addition, the $p$-phenol was shown to play a role in proliferation of ER+ breast cancer cells. If that is the case, then one would not expect the glucuronide and sulfate conjugates to impact proliferation because in that case, the hydrogen in the phenol moiety is actually substituted for a different group (-OH =>-Oglucuronide/-Osulphate). A recent study supports this statement. Tabira et al., 1999, have shown that while phenol itself has weak estrogenic activity, $p$-nonylphenol has maximal estrogenic activity; however, compounds that such as anisole, that have a substituted phenolic group have no estrogenic activity. As for the metabolites formed via NAPQI, they would have relatively bulky substituents in the $m$-position and we and others have shown that such position of a substituent does not favor proliferation (Tabira et al., 1999; Cunningham et al., 1997, Anstead et al., 1997). The only potential metabolites that may influence proliferation would be small, hydrophobic molecules that could diffuse 
across cell membranes. These may include the NAPQI or the deacetylated metabolite, $p$ aminophenol, but the latter metabolite is not formed in humans, only in animals (Prescott, 1996). Thus, it appears most likely that the parent compound is responsible for proliferation of breast cancer cells in vivo. 


\section{Possible Implications}

Most of these studies were conducted in vitro. Given that the in vivo experiment was not conclusive, it is difficult to extrapolate the observed effects to comment on implications for humans. More in vivo data are necessary before one could conclusively state whether these effects of acetaminophen are detrimental, beneficial or insignificant (an in vitro artifact). The data are limited and extrapolations are complex. If, however, one speculated on the implications of these data, then there are two scenarios worth pointing out. The first is: if acetaminophen turns out to stimulate tumor growth in animals and/or ultimately in humans, then acetaminophen use may impact postmenopausal women with undetected breast tumors of the ER+/PR+ type who take acetaminophen frequently. These women may potentially experience tumor growth. Conversely, acetaminophen may ultimately inhibit ER+/PR+ tumors, because it may lower circulating estradiol levels, as Cramer et al. (1998 a, b) suggested. This effect may be especially relevant when estrogen levels are high, such is the case in premenopausal women or women on contraceptives or women on estrogen replacement therapy. In that case, acetaminophen consumption may be beneficial, leading to tumor inhibition.

Some potential experiments that may help elucidate the important question of the effects of acetaminophen in vivo are mentioned below. Since under proper experimental conditions tumors can be maintained in nude mice for more than 2 months (Clarke, 1996), repeats of the nude mice experiments could provide conclusive information regarding the long-term effect of acetaminophen on ER+ breast cancer tumors. Acetaminophen and estradiol implants could be used in this case. The advantage of this type of experiment is that one would study 
the effects of acetaminophen on the same cells on which we observed the effects in vitro, thus, the experiments may have a good chance of producing conclusive results. Alternatively, tumors could be induced easier and faster with a known cancer inducer, such as dimethylbenzanthracene, then acetaminophen could be administered to determine if it stimulates tumor growth. However, in this case, the tumor is not of human origin, so the relevance is to some extent diminished. Nevertheless, such experiment would provide information regarding the potential of acetaminophen to induce or inhibit tumor growth. 


\section{Conclusions}

These studies provide novel information about acetaminophen effects on breast cancer cells, and conclusions drawn from these studies are indicated below. First, acetaminophen can induce in ER+ human breast cancer cells in vitro proliferation, similar to that induced by estradiol. Second, the mechanism by which acetaminophen-induced proliferation occurs is not clear. It is clear, however, that whatever the factor on which acetaminophen acts, that factor is present in ER+ cells while it is absent form the ERalpha- cells. The stimulatory effects induced by acetaminophen occur only in the ER+ cells that were tested. In order for acetaminophen to elicit effects in these cells, they must have either ERs or some other receptors that perhaps are present in all the ER+ cells studied but not in ER- human breast cancer cells. An alternative interpretation would be that perhaps acetaminophen may require not the ER itself but instead some factors/proteins associated with it such as the Hsp90 heterocomplex. Alternatively, acetaminophen may affect some enzymes involved in proliferation that may be present in ER+ but may be absent in ER-cells. Yet another possibility may be that acetaminophen may affect some growth factors involved in proliferation of ER+ breast cancer cells. In either of these cases, the mechanism of acetaminophen-induced proliferation appears to differ from that of estradiol, at least based on results from the whole cell assays where no ER binding was detected.

Another clear conclusion is that the potency of acetaminophen in stimulating ER+ human breast cancer cell proliferation is much lower than that of estradiol, yet the effective concentration of acetaminophen is pharmacologically relevant. As for acetaminophen metabolites in the ER+ cells or their microsomes, it is possible that metabolism may occur in ER+ 
cells but if metabolites form at all, they are minimal and thus undetected by the HPLC method tried. The possibility exists that metabolites of acetaminophen could be involved in proliferation even if they cannot be detected. However, it appears more likely that parent acetaminophen is responsible for the stimulation of proliferation observed in ER+ breast cancer cells in vitro. Overall, these studies contribute to a better understanding of acetaminophen interaction with breast cancer cells in vitro, a research area largely unstudied. 


\section{REFERENCES}

Adams RPL (1988). Cell Culture for Biochemists (TS Worn, Burdon RH, eds). Elsvier Science Publishers, New York.

Amdador E, Dorfman LE, Waker WEC (1963). Serum lactic dehydrogenase activity: an analytical assessment of current assays. Clin Chem 9:391.

Anstead GM, Carlson KE, Katzenellenbogen JA (1997). The estradiol pharmacophore: ligand structure-estrogen receptor binding affinity relationships and a model for the receptor binding site. Steroids 62: 268-303.

Ashby J, Tennant RW (1988). Chemical structure, Salmonella mutagenicity and extent of carcinogenicity as indicators of genotoxic carcinogens. Mutat Res 204:17-115.

Atkinson A, Roy D (1995). In vivo genotoxicity of bisphenol A. Environ Mutagen 26:60-67.

Barkhem T, Carlsson B, Nilsson Y, Enmark E, Gustafsson J, Nilsson S (1998). Differential response of estrogen receptor alpha and estrogen receptor beta to partial estrogen agonists/antagonists. Mol Pharmacol 54:105-12. 
Bergeron JM, Crews D, McLachlan JA (1994). PCBs as environmental estrogens: Turtle sex determination as a biomarker of environmental contamination. Environ Health Perspect 102:780781.

Berkenstam A, Glaumann H, Martin M, Gustafsson JA, Norstedt G (1989). Hormonal regulation of estrogen receptor messenger ribonucleic acid in T47Dco and MCF-7 breast cancer cells. Mol Endocrinol 3: 22-28.

Berne RM, Levy MN (1992). The reproductive glands. In: Physiology, Farrell R, ed, p 10011014.

Berthois Y, Katzenellenbogen JA, Katzenellenbogen BS (1986). Phenol red in tissue culture media is a weak estrogen: implications concerning the study of estrogen-responsive cells in culture. Proc Natl Acad Sci USA 83: 2496-500.

Bhat RA, Harnish DC, Stevis PE, Lyttle CR, Komm BS (1998). A novel human estrogen receptor beta: identification and functional analysis of additional N-terminal amino acids. J Steroid Biochem Mol Biol 67:233-40.

Birnbaum LS (1994). Endocrine effects of prenatal exposure to PCBs, dioxins, and other xenobiotics: implications for policy and future research. Environ Heath Perspect 102:676-79.

Bond GP, McGinnin PM, Cheever KL, Harris $\quad$ SJ, Plotnik $\quad$ HB, Nemeier $\quad$ RW (1980). 
Reproductive effects of bisphenol A. Proc Soc Toxicol 19: A23.

Boone CW, Kelloff GJ, Freedman LS (1993). Intraepithelial and postinvasive neoplasia as a stochastic continuum of clonal evolution, and its relationship to mechanisms of chemopreventive drug action. J Cell Biochem 17G: 14-25.

Boyd EM (1970). Testicular atrophy from analgesic drugs. J Clin Pharmacol 10:222-227.

Brandenberger AW, Tee MK, Lee JY, Chao V, Jaffe RB (1997). Tissue distribution of estrogen receptors alpha (ER-alpha) and beta (ER-beta) mRNA in the midgestational human fetus. J Clin Endocrinol Metab 82:3509-12.

Branham WS, Fishman R, Streck RD, Medlock KL, DeGeorge JJ, Sheehan DM (1996). ICI 182,780 inhibits endogenous estrogen-dependent rat uterine growth and tamoxifen-induced developmental toxicity. Biol Rep 54:160-67.

Brotons JA, Olea-Serano MF, Villabos M, Pedraza V, Olea N (1995). Xenoestrogens released from lacquer coatings in food cans. Environ Health Perspect 103:608-612.

Cabaud PG, Wrowblewski F (1958). Colorimetric measurement of lactic dehydrogenase activity in body fluids. Am J Clin Pathol 30:234.

Castles CG, Klotz, DM, Fuqua SA, Hill SM (1995). Coexpression of wildtype and variant 
oestrogen receptor mRNAs in a panel of human breast cancer cell lines. Br J Cancer 71: 974980.

Castaño E, Chen CW, Vorojeikina DP, Notides AC (1998). The role of phosphorylation in human estrogen receptor function. J Steroid Molec Biochem 65: 101-110.

Ceriani RL, Peterson JA, Blank EW, Chan CM, Cailleau R (1992). Development and characterization of breast carcinoma cell lines as in vitro models for breast cancer diagnosis and therapy. In Vitro Cell Dev Biol 28A:397-402.

Ciocca DR, Fanelli MA (1997). Estrogen receptors and cell proliferation in breast cancer. TEM $8: 313-321$

Clarke R (1996). Human breast cancer cell line xenografts as models of breast cancer - the immunobiologies of recipient mice and the characteristics of several tumorigenic cell lines. Breast Cancer Res Treat 39:69-86.

Clarke R (1995). In vitro models of human breast cancer. In: Diseases of the breast, Harris JR, Hellman S, Lippman ME, Morrow M, eds. Lippincott, Philadelphia, p 245-261.

Colborn T, Vom Saal FS, Soto AM (1993). Developmental effects of endocrine-disrupting chemicals in wildlife and humans. Environ Health Perspect 101:378-384. 
Cramer DW, Harlow BL, Titus-Ernstoff L, Bohlke K, Welch WR, Greenberg ER, (1998a). Overthe-counter analgesics and risk of ovarian cancer. Lancet 351:104-107.

Cramer DW, Liberman RF, Hornstain MD, McShane P, Powers D, Li EY, Barbieri R (1998b). Basal hormone levels in women who use acetaminophen for menstrual pain. Fertil Steril 70:371373.

Cunningham AR, Klopman G, Rosenkranz HS (1997). A dichotomy in the lipophilicity of natural estrogens, xenoestrogens, and phytoestrogens. Environ Health Perspect 105-3: 665-8.

Cutts JH (1964). Estrone-induced mammary tumors in the rat. II. Effect of alterations in the hormonal environment on tumor induction, behavior, and growth. Cancer Res 24:1124-1130.

Dabre P, Yates J, Curtis S (1983). Effect of estradiol on human breast cancer cells in culture. Cancer Res 43:349-353.

Dahlin DC, Miwa GT, Lu AYH, Nelson SD (1984). N-acetyl-p-benzoquinone imine: a cytochrome P-450- mediated product of paracetamol. Proc Natl Acad Sci USA 81: 1327-31.

Davis DL, Telang NT, Osborne MP, Bradlow HL (1997). Medical hypothesis: bifunctional genetic-hormonal pathways to breast cancer. Environ Health Perspect 105: 571-76.

DeCupris A, Favoni RE (1997). Oestrogen/growth factor cross-talk in breast 
carcinoma: a specific target for novel antiestrogens. Trends Pharmacol Sci 18:245-251.

Dotzlaw H, Leygue E, Watson PH, Murphy LC (1997). Expression of estrogen receptor-beta in human breast tumors. J Clin Endocrinol Metab 82:2371-4.

Enan E, Matsumura F (1998). Activation of c-Neu tyrosine kinase by o, p'-DDT and beta-HCH in cell-free and intact cell preparations from MCF7 Human Breast Cancer Cells. J Biochem Mol Toxicol 12:83-92.

Enmark E, Pelto-Huikko M, Grandien K, Lagercrantz S, Lagercrantz J, Fried G, Nordenskjold M, Gustafsson JA (1997). Human estrogen receptor beta - gene structure, chromosomal localization, and expression pattern. J Clin Endocrinol Metab 82:4258-65.

Feuer EJ, Wun LM, Boring CC (1993). The lifetime risk of developing breast cancer. J Natl Cancer Inst 85: 892-897.

Forrest JAH, Clements JA, Prescott LF (1982). Clinical pharmacokinetics of paracetamol. Clin Pharmacokinet 7:93-107.

Fry MD, Toone CK, Speich SM, Peard RJ (1987). Sex ratio skew and breeding patterns of gulls: demographic and toxicological considerations. Stud Avian Biol 10:26-42.

Giovanella BC, Stehlin JS, Williams LJ Jr (1974). Heterotransplantation of human 120 
malignant tumors in nude thymusless mice. II. Malignant tumors induced by injection of cell cultures derived from human solid tumors. J Natl Cancer Inst 52: 921-297.

Gould JC, Leonard LS, Maness, SC, Wagner BL, Conner K., Zacharewski T, Safe S, McDonell, DP, Gaido KW (1998). Bisphenol A interacts with the estrogen receptor $\alpha$ in a distinct manner from estradiol. Mol Cell Endocrinol 142:203-214.

Goldin BR (1994). Nonsteroidal estrogens and estrogen antagonists: mechanisms of action and health implications. J Natl Cancer Inst 86:1741-1742.

Graham ML 2d, Krett NL, Miller LA, Leslie KK, Gordon DF, Wood WM, Wei LL, Horwitz KB (1990). T47Dco cells, genetically unstable and containing estrogen receptor mutations, are a model for the progression of breast cancers to hormone resistance. Cancer Res 50: 6208-6217.

Graham ML 2d, Dalquist KE, Horwitz KB (1989). Simultaneous measurement of progesterone receptors and DNA indices by flow cytometry: analysis of breast cancer cell mixtures and genetic instability if the T47D line. Cancer Res 49:3943-3949.

Guillette LJ Jr, Gross TS, Masson GR, Matter JM, Percival HF, Woodward AR (1994). Developmental abnormalities of the gonad and abnormal sex hormone concentrations in juvenile alligators from contaminated and control lakes in Florida. Environ Health Perspect 102:680-687.

Guzelian PS (1982). Comparative toxicology of chlordecone (kepone) in humans and 121 
experimental animals. Ann Rev Pharmacol Toxicol 22:89-113.

Haney AF, Hughes SF, Hughes CL Jr (1987). Effects of acetaminophen and nonsteroidal antiinflammatory drugs on progesterone production by porcine granulosa cells in vitro. Reprod Toxicol 1:285-291.

Harnagea-Theophilus E, Miller MR (1998). Acetaminophen alters estrogenic responses in vitro: stimulation of DNA synthesis in estrogen-responsive breast cancer cells. Tox Sci 46:38-44.

Harnagea-Theophilus E, Gadd SL, Knight-Trent AH, DeGeorge GL, Miller MR (1999). Acetaminophen-induced proliferation of breast cancer cells involves estrogen receptors. Tox Appl Pharm 155:273-9.

Herbst AL, Hubby MM, Bough RR, Azizi F (1992). A comparison of pregnancy experience in DES-exposed and DES-unexposed daughters. J Reprod Med 24:62-69.

Holme JA, Hongslo JK, Bjornstad C, Harvison PJ, Nelson SD (1988). Genotoxic effects of paracetamol in V79 Chinese hamster cells. Mutagenesis 3:51-56.

Holme JA, Sonderlund E (1986). Species differences in cytotoxic and genotoxic effects of phenacetin and paracetamol in primary monolayer cultures of hepatocytes. Mut Res 164:167175. 
Honsglo JK, Christensen T, Brunborg G, Bjornstad C, Holme JA (1988). Genotoxic effects of paracetamol in V79 Chinese hamster cells. Mut Res 204:333-341.

Horwitz KB, Freidenberg GR (1985). Growth inhibition and increase of insulin receptors in antiestrogen-resistant T47Dco human breast cancer cells by progestins: implications for endocrine therapy. Cancer Res 45:167-173.

Horwitz KB, Wei LL, Francis MD (1986). Structural analyses of progesterone receptors. J Steroid Biochem 24: 109-117.

Horwitz KB, Sheridan PL, Wei LL, Krett NL (1990). Human progesterone receptors: synthesis, structure, and phosphorylation. Prog Clin Biol Res 322:41-52.

Hovland AR, Powell RL, Takimoto GS, Tung L, Horwitz KB (1998). An N-terminal inhibitory function, IF, suppresses transcription by the A-isoform but not the B-isoform of human progesterone receptors. J Biol Chem 273:5455-5460.

IARC. Monograph (1979). Sex hormones. IARC Monogr Eval Carcinogen Risk Chem Hu 21:173-221.

Inano K, Curtis SW, Korach KS, Omata S, Horigome T (1994). Heat shock protein 90 strongly stimulates the binding of purified estrogen receptor to its responsive element. J Biochem 116: $755-766$. 
Isenhower WD, Newbold RR, Cefalo RC, Korach KS, McLachlan JA (1986). Absence of estrogenic activity in some drugs commonly used during pregnancy. Biol Res Pregnancy 7:6-10.

Jensen KG, Poulsen HE, Doemer J, Loft S (1996). Paracetamol-induced spindle disturbances in V79 cells with and without expression of human CYP1A2. Parmacol Toxicol 78:224-228.

Kasid A, Bronzert D, Lippman M (1985). Estradiol responsive human breast cancer cells in culture. In: Mechanism of sex steroids, Auricchio, ed, Field Educational Italia Acta Medica, p 238-255.

Kastrup EK, Ed (1981). Antipyretic analgesics. In: Facts and Comparisons. Facts and Comparisons Inc, St Louis, p 774-777.

Katzenellenbogen BS (1996). Estrogen receptors: bioactivities and interactions with cell signaling pathways. Biol Reprod 54: 287-293.

Katzenellenbogen BS, Montano MM, Ekena K, Herman ME, McInerney EM (1997). Antiestrogens: mechanism of action and resistance in breast cancer. Br Cancer Res Treatm 44: 22-38.

Katzenellenbogen BS, Korach KS (1997). A new actor in the estrogen receptor drama enters ERbeta [editorial]. Endocrinology 138:861-862. 
Keightley M-C (1998). Steroid receptor isoforms: exception or rule? Mol Cell Endocrinol 137: $1-5$.

Kelloff GJ, Boone CW, Steele VE (1994). Progress in cancer chemoprevention: perspectives on agent selection and short-term clinical intervention trials. Cancer Research 54: 2015s-2024s.

Knaak JB, Sullivan LJ (1966). Metabolism of bisphenol A in the rat. Toxicol Appl Pharmacol 18:175-184.

Krishnan AV, Stathis P, Permuth SF, Tokes L, Feldman D (1993). Bisphenol A: An estrogenic substance is released from polycarbonate flasks during autoclaving. Endocrinology 132:22792286.

Kuiper GG, Shughrue PJ, Merchenthaler I, Gustafsson JA (1998). The estrogen receptor beta subtype: a novel mediator of estrogen action in neuroendocrine systems. Front Neuroendocrinol 19:253-86.

Kuiper GGJ, Carlsson MB, Grandien K, Enmark E, Häggblad J, Nilsson S, Gustafsson J (1997). Comparison of the ligand binding specificity and transcript tissue distribution of estrogen receptors alpha and beta. Endocrinology 138:863-870.

Kuiper GG, Enmark E, Pelto-Huikko M, Nilsson S, and Gustafsson JA (1996). Cloning 125 
of a novel receptor expressed in rat prostate and ovary. Proc Natl Acad Sci USA 93:5925-5930.

Lee MJ, Gee P, Beard SE (1997). Detection of peroxisome proliferators using a reporter construct derived from the rat acyl-CoA oxidase promoter in the rat liver cell line H-4-II-E. Cancer Res 57:1575-9.

Lee AV, Jackson JG, Gooch JL, Hilsenbeck SG, Coronado-Heinsohn E, Osborne CK, Yee D (1999). Enhancement of insulin-like growth factor signaling in human breast cancer: estrogen regulation of insulin receptor substrate-1 expression in vitro and in vivo. Mol Endocrinol $13: 787-96$.

Leslie KK, Tasset DM, Horwitz KB (1992). Functional analysis of mutant estrogen receptor isolated from T47Dco breast cancer cells. Am J Obstet Gynecol 166:1053-1061.

Lieberman BA (1997). The estrogen receptor activity cycle: dependence on multiple proteinprotein interactions. Crit Rev Euk Gene Express. 7:43-59.

Lipscomb JC, Confer PD, Miller MR, Stamm SC, Snawder JE, Bandiera SM (1998). Metabolism of trichloroethylene and chloral hydrate by the Japanese medaka (Oryzias laptides) in vitro. Environ Tox Chem 17:325-332.

Lu B, Leygue E, Dotzlaw H, Murphy LJ, Murphy LC, Watson PH (1998). Estrogen receptorbeta mRNA variants in human and murine tissues. Mol Cell Endocrinol 138:199-203. 
Malone K (1993). Diethylstilbestrol (DES) and breast cancer. Epidemiol Rev 15:108-109.

Marselos M, Tomatis L (1992) Diethylstilbestrol: I. Pharmacology, toxicology and carcinogenicity in humans. Eur J Cancer 28A:1182-1189.

Martineau D, Lagace A, Beland P, Higgins R, Armstrong D, Shugart LR (1988). Pathology of stranded Beluga whales (Delphinapterus leucas) from St. Laurence Estuary, Quebec, Canada. J Comp Path 98: 287-311.

McLachlan JA, Newbold RR, Nelson KC, Korach KS (1993). Functional toxicology: A new approach to detect biologically active xenobiotics. Environ Health Perspect 101:386-387.

Mellanon P, Petanen T, Lehtimaki J, Makela S, Bylund G, Holmborn B, Manilla E, Oikari A, Santti R (1996). Wood-derived estrogens: studies in vitro with breast cancer cells lines and in vivo with trout. Tox Appl Pharmacol 136: 381-388.

Miller MR, Wentz E, Ong S (1999). Acetaminophen alters estrogenic responses in vitro: inhibition of estrogen-dependent vitellogenin production in trout liver cells. Tox Sci 48:30-37.

Miners DJ, Kissinger PT (1979). Evidence for the involvement of N-acetyl-p-quinoneimine in paracetamol metabolism. Biochem Pharmacol 28: 3285-90. 
Mosselman S, Polman J, Dijkema R (1996). ER beta: identification and characterization of a novel human estrogen receptor. FEBS Lett. 392:49-53.

Nagel SC, vom Saal FS, Welson WV (1998). The effective free fraction of estradiol and xenoestrogens in human serum measured by whole cell uptake assays: physiology of delivery modifies estrogenic activity. PSEBM 217: 300-309.

Neckers LM, Mimnaugh E, and Schulte TW (1998). The Hsp90 chaperone family. In: Stress Proteins. Handbook of Experimental Pharmacology, Latchman DS, ed. Heidelberg: SpringerVerlag 136, 9-42.

Noyes WR, Mulcahy RT, Craig BA, Kinsella TJ (1996). Effect of a pure anti-estrogen, ICI 182,780 , on the in vitro radiosensitivity of MCF-7 breast carcinoma cells. Radiat Oncol Invest 3 : $232-237$.

Osborne CK, Wiebe VJ, McGuire WL, Ciocca DR, Degregorio MW (1992). Tamoxifen and the isomers of 4-hydroxytamoxifen in tamoxifen-resistant tumors from breast cancer patients. J Clin Oncol 10: 304-10.

Osborne CK, Coronado-Heinsohn EB, Hilsenbeck SG, McCue BL, Wakeling AE, McClelland RA, Manning DL, Nicholson RI (1995). Comparison of the effects of a pure steroidal antiestrogen with those of tamoxifen in a model of human breast cancer. J Natl Cancer Inst 87: $746-750$. 
Ongphiphadhanakul B, Rajatanavin R, Chanprasertyothin S, Piaseu N, Chailurkit L (1998). Serum oestradiol and oestrogen-receptor gene polymorphism are associated with bone mineral density independently of serum testosterone in normal males. Clin Endocrinol (Oxf) 49:803-9.

Pedeutour F, Quade BJ, Weremowicz S, Dal Cin P, Ali S, Morton CC (1998). Localization and expression of the human estrogen receptor beta gene in uterine leiomyomata. Genes Chromosomes Cancer 23:361-6.

Pennisi E (1997). Differing roles found for estrogen's two receptors. Science 277:1439.

Petersen DN, Tkalcevic GT, Koza-Taylor PH, Turi TG, Brown TA (1998). Identification of estrogen receptor beta2, a functional variant of estrogen receptor beta expressed in normal rat tissues. Endocrinology 139:1082-92.

Prescott, L (1996). Paracetamol (Acetaminophen). A critical bibliographic review. Taylor and Francis Inc., PA.

Raloff J (1993). Ecocancers. Do environmental factors underlie a breast cancer epidemic? Science News 144:10-13.

Rajendran KG, Lopez T, Parikh I (1987). Estrogenic effects of phenol red in MCF-7 cells is achieved through activation of estrogen receptor by interacting with a site distinct from 
the steroid binding site. Biochem Biophys Res Commun 142:724-31.

Reel JR, Davis Lawton A, Lamb IV JC (1992). Reproductive toxicity evaluation of acetaminophen in Swiss CD-1 mice using a continuous breeding protocol. Fund Appl Toxicol 18:233-239.

Register TC, Adams MR (1998). Coronary Artery cultured aortic muscles express mRNA for both the classical ER and the newly discovered ER beta. J Steroid Biochem Mol Biol 64:187-91.

Reijnders PJH. (1986). Reproductive failure of common seals feeding on fish from polluted coastal waters. Nature 324:256-457.

Roy D, Palangat M, Chen CW, Thomas RD, Colerangle J, Alkinson A, Yan ZJ (1997). Biochemical and molecular changes at the cellular level in response to exposure to environmental estrogen-like chemicals. J Toxicol Environ Health 50:1-29.

Safe SH (1995). Environmental and dietary estrogens and human health: Is there a problem? Environ Health Perspect 103:346-351.

Sartorius CA, Groshong SD, Miller LA, Powell RL, Tung L, Takimoto GS, Horwitz KB (1994). New T47D breast cancer cell lines for the independent study of progesterone B- and A-receptors: only antiprogestin-occupied B-receptors are switched to transcriptional agonists by cAMP. Cancer Res 54:3868-3877. 
Schonberg SA, Skorpe F (1997). Paracetamol counteracts decosahexanoic acid-induced growth inhibition of A-427 lung carcinoma cells and enhances tumor cell proliferation in vitro. Anticancer Res 17: 2443-8.

Sheridan PL, Francis MD, Horwitz KB (1989). Synthesis of human progesterone receptors in T47D cells. Nascent A- and B-receptors are active without a phosphorylation-dependent posttranslational maturation step. J Biol Chem 264:7054-8.

Shymala G (1985). Estrogen and progesterone receptors from mammary gland. In: Mechanism of sex steroids (Auricchio, ed.) Field Educational Italia Acta Medica, 238-255.

Smith CL (1998). Cross-talk between peptide growth factor and estrogen receptor signaling pathways. Biol Reprod 58:627-632.

Soto AM, Justicia H, Wray JW, Sonnenschein C (1991). p-Nonylphenol: an estrogenic xenobiotic released from "modified" polystyrene. Environ Health Perspect 92:167-173.

Stampfer ME, Bartley J (1987). Growth and transformation of human mammary epithelial cells in culture. In: Cellular and molecular biology of mammary cancer, Medina D, Kidwell W, Heppner G, Anderson E, eds. New York, Plenum Press, p 419-36.

Stillman RJ (1982). In utero exposure to diethylstilbestrol: adverse effects on the 
reproductive tract and reproductive performance in male and female offspring. Am J Obstret Gynecol 142: 905-921.

Strobl SJ, Kasid A, Huff KK, Lippman ME (1984). Kinetic alterations in estrogen receptors associated with estrogen receptor processing in human breast cancer cells. Endocrinol 115: 11161124.

Tabira Y, Nakai M, Asai D, Yakabe Y, Tahara Y, Shinmyozu T, Noguchi M, Takatsuki M, Shimohigashi Y (1999). Structural requirements of para-alkylphenols to bind to estrogen receptor. Eur J Biochem 262:240-45.

Takimoto GS, Tasset DM, Eppert AC, Horwitz KB (1992). Hormone-induced progesterone receptor phosphorylation consists of sequential DNA-independent and DNA-dependent stages: analysis with zinc finger mutants and the progesterone antagonist ZK98299. Proc Natl Acad Sci USA 89:3050-3054.

Taskinen H, Lindbohm M-L, Hemminki K (1986). Spontaneous abortions among women working in pharmaceutical industry. Br J Industr Med 43: 199-205.

Teicher BA, Holden S, Ar, G, Liu J-TC, Robinson MF, Flodgren P, Dupuis N, Northey D (1993). Cyclooxygenase inhibitors: in vitro and in vivo effects on antitumor alkylating agents in the EMT-6 murine mammary carcinoma. Int J Oncol 2:145-153. 
Tremblay GB, Tremblay A, Copeland NG, Gilbert DJ, Jenkins NA, Labrie F, Giguere V (1997). Cloning, chromosomal localization, and functional analysis of the murine estrogen receptor beta. Mol Endocrinol 11:353-65.

Tsuda H, Sakata T, Masui T, Imida K, Ito N (1984). Modifying effects of butylated hydroxoanisole, ethoxyquin and acetaminophen on the induction of neoplastic lesions in rat liver and kidney initiated by N-ethyl-N-hydroxyethylnitrosamine. Carcinogenesis 5:525-531.

Vegeto E, Shabaz MM, Wen DX, Goldman ME, O'Malley BW, McDonnell DP (1993). Human progesterone receptor $\mathrm{A}$ form is a cell and promoter specific repressor of human progesterone receptor B function. Mol Endocrinol 7: 1244-1255.

Vladusic EA, Hornby AE, Guerra-Vladusic FKR (1998). Expression of estrogen receptor beta messenger RNA variant in breast cancer. Cancer Res 58:210-4.

Vorherr H (1967). Physiology of estrogens. In: The Breast: Morphology, Physiology, Lactation. New York, Academic Press, p 316-317.

Weigel NL, Zhang Y (1998). Ligand-independent activation of steroid hormone receptors. J Mol Med 76:469-479.

Weisburger JH, Weisburger EK, Madison RM, Wenk ML, Klein DS (1973). Effect of acetanilide and $\quad$-hydroxy-acetanilide on the carcinogenicity of $\mathrm{N}$-2-fluoronylacetamide and 
N-hydroxy-N-2-fluorenylacetamide in mice, hamsters and female rats. J Natl Cancer Inst 51:235-240.

White R, Jobling S, Hoare AA, Sumpter JP, Parker MG (1994). Environmentally persistent alkylphenolic compounds are estrogenic. Endocrinology 135:175-182.

Williams GM, Iatropoulos MJ (1997). Inhibition by acetaminophen of intestinal cancer in rats induced by an aromatic amine similar to food mutagens. Eur J Cancer Prev 6: 357-62.

Zaher H, Buters JT, Ward JM, Bruno MK, Lucas AM, Stern ST, Cohen SD, Gonzalez FJ (1998). Protection against acetaminophen toxicity in CYP1A2 and CYP2E1 double-null mice. Tox Appl Pharm 152: 193-199.

Zhang Y, Beck CA, Poletti A, Edwards DP, Weigel NL (1994). Identification of phosphorylation sites unique to the $\mathrm{B}$ form of human progesterone receptor: in vitro phosphorylation by casein kinase II. J Biol Chem 269: 31034-31040.

Zhang Y, Beck CA, Poletti A, Clement IV JP, Prendergast P, Yip TT, Hutchens TW, Edwards DP, Weigel NL (1997). Phosphorylation of human progesterone receptor by cyclin-dependent kinase 2 on three sites that are authentic basal phosphorylation sites in vivo. Mol Endocrinol 11:823-32. 


\section{Eugenia Harnagea Theophilus}

Pharmacology \& Toxicology Department, West Virginia University, P. O. Box 9223

Morgantown, WV 26506-9223, Email: eharnage@wvu.edu

Day Telephone: (304) 293-0226, Evening Telephone: (304) 296-1985, Fax: (304) 293-6846

\section{Education and Experience}

\section{7-1992 BS MS Physical Chemistry, Education, Al. I. Cuza University, Iasi, Romania 1992-1995 MS Chemistry, West Virginia University, Morgantown, WV}

Research. Conducted 2 projects finalized in paper and thesis. Planned, organized, designed and conducted research using RAMAN and IR spectroscopies. Teaching. Trained and supervised chemistry undergraduate students. Extracurricular. Associate editor for 2 magazines.

1995-1999 PhD Pharmacology \& Toxicology, West Virginia University, Morgantown, WV

Research. Proposed, planned, organized and conducted research related to cancer, safety pharmacology and toxicology. Conducted assays based on existing literature to characterize hormone- and drug-induced effects and mechanisms of proliferation, toxicity, apoptosis. Monitored in culture: normal and cancer cell proliferation, DNA synthesis; cell toxicity and apoptosis; receptor levels and binding; metabolism enzymes induction, metabolite levels; in animals: tumor growth and hormone/drug/metabolite levels. Collected, interpreted data, summarized information; initiated manuscript writing, wrote, edited, managed manuscript publication. Retrieved, synthesized information, organized, and wrote reviews. Wrote abstracts and posters; presented data at national/regional scientific meetings. Wrote grants. Teaching. Assisted medical student conferences, trained/supervised undergraduate and graduate students. 1992-1999 Research and teaching assistantship positions at West Virginia University, Chemistry and Pharmacology \& Toxicology Departments. 


\section{Honors}

1988, 1990, 1991, 1992 Al. I . Cuza Scholarships for Academic Accomplishments 1992 Soros Foundation Travel Award

1995, 1996, 1997, 1998 Swiger Fellowship Supplements

1998 1st place - Van Liere Research Communication Convocation Competition 1998 Sigma Xi Graduate Student Award for Research Excellence, School of Medicine, WVU 1999 Van Liere Competition Committee 1999 National Society of Toxicology Graduate Student Travel Award 1999 Proctor and Gamble/Novartis-SOT Graduate Student Fellowship Finalist 1999 Regional AESOT Graduate Student Research Award

\section{Societies}

National Society of Toxicology

Allegheny-Erie Regional Chapters Society of Toxicology

Sigma Xi Scientific Research Society

Sigma Delta Epsilon Graduate Women in Research

\section{Publications}

Harnagea-Theophilus, E., Gadd, S. L., Knight-Trent, A. H., De George, G. L, Miller, M. R. (1999). Acetaminophen-induced proliferation involves estrogen receptors. Toxicology and Applied Pharmacology, 155, 155, 273-279.

Harnagea-Theophilus, E. and Miller, M. R. (1999). Similarities between acetaminophen- and estradiol-induced proliferation of cultured, estrogen-responsive breast cancer cells. Toxicological Sciences, 48 (1-S), 379.

Harnagea-Theophilus, E., Miller, M. R. and Rao, N. (1999). Positional isomers of acetaminophen differentially induce proliferation of cultured breast cancer cells. Toxicology Letters, 104:11-18. 
Harnagea-Theophilus E. and Miller, M. R. (1999). Paracetamol metabolism. A minireview and consideration of best animal models. Xenobiotica. Outline pre-approved.

Harnagea-Theophilus, E. and Miller, M. R. (1998). Acetaminophen alters estrogenic responses in vitro: stimulation of DNA synthesis in estrogen-responsive human breast cancer cells. Toxicological Sciences 46, 38-44.

Harnagea-Theophilus, E. and Miller, M. R. (1998). Society of Toxicology workshop on effects and mechanistic aspects of tamoxifen action. International Journal of Cancer, 78, 401-403.

Harnagea, E. and Miller, M. R. (1998). Acetaminophen is a xenoestrogen in vitro. Toxicologist, 42, 1-S, 175.

Miller, M. R., Harnagea, E., Knight-Trent, A. H., Judy, D., DeGeorge, G. L. (1998). Comparison of the estrogenic potential of acetaminophen in several assay systems. Toxicologist, 42, 1-S, 175.

Harnagea, E. I. and Jagodzinski, P. W. (1996). Infrared spectra of cyclic and noncyclic ureas in solution: structures and interactions. Vibrational Spectroscopy 10: 169-175.

Harnagea, E. I. Induced cataract development in eye lenses. A RAMAN spectroscopic study. Thesis. 